\title{
ANGELA FALCAI
}

Fatores genéticos, exposição ambiental, mecanismos imunológicos e o desenvolvimento da sibilância e da asma na infância

Tese apresentada ao Programa de PósGraduação em Imunologia do Instituto de Ciências Biomédicas da Universidade de São Paulo, para obtenção do Título de Doutor em Ciências. 


\section{ANGELA FALCAI}

Fatores genéticos, exposição ambiental, mecanismos imunológicos e o desenvolvimento da sibilância e da asma na infância

Tese apresentada ao Programa de PósGraduação em Imunologia do Instituto de Ciências Biomédicas da Universidade de São Paulo, para obtenção do Título de Doutor em Ciências.

Área de Concentração: Imunologia

Orientador: Antonio Condino Neto 
DADOS DE CATALOGAÇÃO NA PUBLICAÇÃO (CIP)

Serviço de Biblioteca e Informação Biomédica do

Instituto de Ciências Biomédicas da Universidade de São Paulo

(ํ) reprodução total

Falcai, Angela.

Fatores genéticos, exposição ambiental, mecanismos imunológicos e o desenvolvimento da sibilância e asma na infância / Angela Falcai. -- São Paulo, 2010.

Orientador: Antonio Condino Neto.

Tese (Doutorado) - Universidade de São Paulo. Instituto de Ciências Biomédicas. Departamento de Imunologia. Área de concentração: Imunologia. Linha de pesquisa: Sibilância e asma na infância.

Versão do título para o inglês: Genetic factors, environmental exposure, immune mechanisms and develpment of wheezing and asthma.

Descritores: 1. Imunologia 2. Imunologia celular 3. Endotoxina 4. Citocinas 5. Polimorfismos 6. Asma I. Condino Neto, antonio II. Universidade de São Paulo. Instituto de Ciências Biomédicas. Programa de Pós Graduação em Imunologia III. Título. 
Candidato(a): $\quad$ Angela Falcai.

Título da Tese: $\quad$ Fatores genéticos, exposição ambiental, mecanismos imunológicos e o desenvolvimento da sibilância e asma na infância .

Orientador(a): $\quad$ Antonio Condino Neto.

A Comissão Julgadora dos trabalhos de Defesa da Tese de Doutorado, em sessão pública realizada a .../...... considerou

\section{( ) Aprovado(a) \\ ( ) Reprovado(a)}

Examinador(a):

Assinatura:

Nome:

Instituição:

Examinador(a): Assinatura:

Nome:

Instituição:

Examinador(a): Assinatura:

Nome:

Instituição:

Examinador(a): Assinatura:

Nome:

Instituição:

Presidente: Assinatura:

Nome:

Instituição: 
UNIVERSIDADE DE SÃO PAULO

INSTITUTO DE CIÊNCIAS BIOMÉDICAS

Cidade Universitária "Armando de Salles Oliveira"

Paulo, SP - Brasi

ax: (55) (11) 3091-7438

e-mail: cep@ icb.usp.br

São Paulo, 16 de novembro de 2006.

\section{PARECER 757/CEP}

Prezada Senhora,

Atendendo sua solicitação, a Comissão de Ética em Pesquisas com Seres Humanos do ICB, em sua $70^{\mathrm{a}}$ reunião realizada em 14.11.o6, analisou o projeto de sua responsabilidade intitulado: "Estudo dos mecanismos moleculares e cehulares da immidade inata que regem a fisiopatologia da asma”.

Informo a V.Sa. que, após análise e discussão, o referido projeto foi aprovado por esta Comissão.

Esclareço a V.Sa. que dentro de 12 meses, relatório do referido projeto deverá ser encaminhado à Secretaria deste CEP.

Atenciosamente,

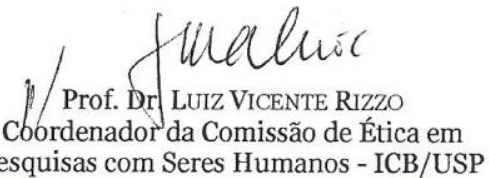

Ilma. Sra.

ÂNGELA FALCAI

Departamento de Imunologia

Instituto de Ciências Biomédicas -USP

Comissão de Ética em Pesquisa com Seres Humanos do Instituto de Ciências Biomédicas / USP Aprovada pela Comissāo Nacional de Ética em Pesquisa - CONEP, em 10 de fevereiro de 1998 
Aos amores da minha vidas, meu esposo Paulo Vítor e meu filho Paulo Gabriel pelo amor, carinho, dedicação, compreensão e acima de tudo paciência em todos os momentos!!!!

À minha mãe Cleonice pelo carinho e apoio incondicional durante toda minha vida! Meus agradecimentos pela educação sempre primorosa! 


\section{AGRADECIMENTOS}

Agradeço a Deus por ter me dado força e sabedoria para conseguir chegar até aqui.

Aos meus pais Cleonice e Ângelo pelo dom da vida;

Às minhas irmãs Tânia e Márcia e sobrinhos Matheus, Bianca e Letícia por todo amor e carinho. Devo muito esta conquista ao seu incentivo, respeito e apoio; sem vocês esta etapa jamais teria se concretizado. Obrigada por tudo! Amo muito vocês;

Ao Prof. Dr. Antonio Condino Neto, orientador, conselheiro e amigo. Obrigada por ter me acolhido em seu laboratório. Agradeço primeiramente por ter acreditado em mim, por ter me ensinado a pensar cientificamente e por sua enorme contribuição, em minha evolução como profissional e ser humano. Pude chegar à reta final desse trabalho, em virtude da sua paciência, dedicação e carinho. Devo somente a Deus por ter lhe colocado em meu caminho. Jamais poderei esquecê-lo;

Ao Prof. Dr. Dirceu Solé, Dra. Vera Rullo e Dra. Carolina Sanches pela colaboração científica e seleção dos pacientes que foram recrutados para esta tese. À Dra. Maria Candida Rizzo por ter selecionado pacientes para conclusão do trabalho;

Aos amigos e companheiros de trabalho do Laboratório de Imunologia Humana: Paulo Vítor, Otavio, Walmir, Josias, Stephanie e Paolo. Aos integrantes que vieram de Campinas e se juntaram a nós: Edgar, Mateo, Soraia e Caru. Aos novos integrantes do grupo: Marília, Marina e Adriana. Ao Éric, bioinformata do laboratório;

À amiga de todas as horas, do laboratório e da vida, à vizinha de bancada, à técnica do laboratório, Christina, por toda atenção, carinho, eficiência, disposição em resolver qualquer problema, além de colaboradora do trabalho por ter dosado as citocinas; 
Á Silvana, pela amizade e carinho. Obrigada por resolver nossos problemas administrativos e burocráticos;

Aos colegas de departamento: Julieta, Érica e Rafael, Alexandra e Lucas, Zé, que ao longo do tempo tornaram-se grandes amigos e ótimas companhias nos momentos mais inusitados;

Aos professores do Departamento de Imunologia do ICB pelo carinho e auxílio durante a minha formação;

Aos amigos Auérea, Otacílio, Milton, Moisés, Jotelma, Eni, Amanda e Thiago pela amizade e assistência e a todos os funcionários com quem tive o prazer de conviver por esses anos;

À Fundação de Amparo à Pesquisa do Estado de São Paulo pela suporte financeiro e auxílios recebidos durante o doutorado;

E a todos aqueles que direta ou indiretamente contribuíram para que este estudo fosse concluído.

"Cada um que passa em nossa vida, passa sozinho, porque cada pessoa é única para nós, e nenhuma substitui a outra... Cada um que passa em nossa vida, passa sozinho, mas não vai só... Cada um que passa em nossa vida leva um pouco de nós mesmos, e nos deixa um pouco de si mesmo... Há os que levam muito, mas há os que não levam nada... Essa é a mais bela realidade da vida. A prova tremenda da importância de cada um é que ninguém se aproxima do outro por acaso". (Antoine de Saint-Exupéry) 
"Ainda que eu fale as línguas dos homens e dos anjos, se não tiver amor, serei como o bronze que soa, ou como o címbalo que retine.

Ainda que eu tenha o dom de profetizar e conheça todos os mistérios e toda a ciência; ainda que eu tenha tamanha fé, a ponto de transportar montanhas, se não tiver amor, nada serei..."

Acima de tudo o amor (trecho da carta de São Paulo aos coríntios). 


\section{RESUMO}

FALCAI A, Fatores genéticos, exposição ambiental, mecanismos imunológicos e o desenvolvimento da sibilância e da asma na infância. [tese (Doutorado em Imonulogia)]. Instituto de Ciências Biomédicas, Universidade de São Paulo; 2010

Introdução: A síndrome do lactente sibilante é definida pela presença de sibilância contínua por um mês ou três episódios de chiado num período de seis meses, em crianças menores de dois anos de idade. A asma é caracterizada pela obstrução, hiperresponsividade brônquica e inflamação das vias áreas, em crianças maiores de cinco anos de idade. Mesmo com o constante avanço no esclarecimento dos aspectos dessas patogenias, existem inúmeras controvérsias no conhecimento sobre exposição à endotoxina, background genético, ativação celular, liberação de mediadores, quando relacionados ao desenvolvimento dessas desordens. Objetivo: Investigar as relações entre exposição à endotoxina ambiental, o papel do LPS em ativar leucócitos do sangue periférico, prevalência de polimorfismos genéticos e o desenvolvimento dos fenótipos de sibilância e asma na infância. Materiais e Métodos: Para este estudo foram selecionados dois grupos distintos, 86 lactentes sibilantes e não sibilantes e 86 crianças asmáticas e não asmáticas. Estas foram avaliadas clinicamente e o seu sangue coletado. PBMC foram cultivadas ou não com LPS e o sobrenadante foi colhido para análises das citocinas IL-4, IL-5, IL-10, IL-17, TNF- $\alpha$, IFN- $\gamma$, IL-12 por meio de ELISA. Também realizamos a extração de DNA para análises dos polimorfismos de CD14 (C-159T) e TLR4 (Asp299Gly) por PCR-RFLP. Resultados: No primeiro grupo de crianças (lactentes sibilantes), observamos que infecções respiratórias estão associadas ao estabelecimento de sibilância. A exposição à endotoxina ambiental no início da vida não teve um papel essencial no quadro de sibilância. As PBMC de crianças sibilantes apresentam menor produção de IFN- $\gamma$ e IL-12 comparadas a crianças não sibilantes, independente do nível de exposição precoce a endotoxina. Os polimorfismos de TLR4 e CD14 não estão associados ao fenótipo da sibilância. Entretanto, o polimorfismo no gene de CD14 está associado à sensibilização aos alérgenos de barata e fungos e uma maior produção espontânea de IFN- $\gamma$ e IL-10 por PBMC de crianças não sibilantes. No segundo grupo de estudo (crianças asmáticas), observamos que PBMC de crianças asmáticas produziram espontaneamente e após estímulo com LPS baixas quantidades de IL-12p70, IFN- $\gamma$, IL-10, IL-17, IL-4 e alta quantidade de IL-5 quando comparados com crianças não asmáticas. Também não observamos uma associação entre os polimorfismos de TLR4 e CD14 com o fenótipo da asma. Conclusões: Em conjunto, nossos dados demonstraram que PBMC estimuladas ou não com LPS de crianças sibilantes e asmáticas produziram baixas quantidades de IL-12 e IFN- $\gamma$ quando comparados com crianças não sibilantes e não asmáticas. A produção reduzida dessas citocinas pode influenciar na alta incidência de infecções respiratórias em crianças sibilantes, bem como pode se associar com o direcionamento da produção de citocinas para um padrão Th2. O polimorfismo de CD14, apesar de não influenciar diretamente no desenvolvimento dos fenótipos de sibilância e asma, regula as repostas imunes analisadas.

Palavras-Chaves: Sibilância. Asma. Citocinas. Endotoxina. Polimorfismos. 


\begin{abstract}
FALCAI, A. Genetic factors, environmental exposure, immune mechanisms and the development of wheezing and asthma in childhood. $[\mathrm{Ph}$. $\mathrm{D}$. thesis (Immunology)]. Instituto de Ciências Biomédicas da Universidade de São Paulo; 2010.
\end{abstract}

Introduction: The syndrome of infant wheezing is defined by the presence of continuous wheezing by one month or three episodes of wheezing during six months, in children under two years old. Asthma is characterized by airflow obstruction, bronchial hyperresponsiveness and inflammation of airways, in children older than five years old. Even with the steady progress in clarifying aspects of these pathologies, there are numerous controversies in knowledge about endotoxin exposure, genetic background, cell activation, mediators release, when related with the development of these disorders. Objective: Investigate the relationship between environmental exposure to endotoxin, the role of LPS in activating peripheral blood leukocytes, prevalence of genetic polymorphisms and development of asthma and wheezing phenotypes in childhood. Materials and Methods: For this study we selected two groups, 86 wheezing and non-wheezing children and 86 asthmatic and non-asthmatic children. These were evaluated clinically and its blood collected. PBMC were cultured with or without LPS and the supernatant was collected for analysis of IL-4, IL-5, IL-10, IL-17, TNF- $\alpha$, IFN- $\gamma$, IL-12 by ELISA. We also performed the extraction of DNA for analysis of polymorphisms of CD14 (C-159T) and TLR4 (Asp299Gly) by PCRRFLP. Results: In the first group of children (wheezing infants), we observe that respiratory infections are associated with the establishment of wheezing. Environmental exposure to endotoxin early in life had not a key role in the context of wheezing. PBMC from wheezing children presented lower production of IFN- $\gamma$ and IL-12 compared to non-wheezing children, independently of the level of early exposure to endotoxin. Polymorphisms of TLR4 and CD14 are not associated with phenotype of wheezing. However, polymorphism in the CD14 gene is associated with sensitization to cockroach allergens, molds and a higher spontaneous production of IFN- $\gamma$ and IL-10 by PBMC of non-wheezing children. In the second group of study (asthmatic children), we observed that PBMC from asthmatic children spontaneously and LPS-stimulated releases low amounts of IL-12p70, IFN- $\gamma$, IL-10, IL-17, IL-4 and high amounts of IL -5 compared with non-asthmatic children. We did not observe an association between TLR4 and CD14 polymorphisms and the phenotype of asthma. Conclusions: Taken together, our data demonstrate that PBMC from wheezing and asthmatic children stimulated or not with LPS produced low amounts of IL-12 and IFN- $\gamma$ when compared with children non-wheezing and non-asthmatic. The low production of these cytokines may influence on high incidence of respiratory infections in wheezing children, and may be associated with the direction of cytokine production to a Th2 pattern. The polymorphism of CD14, although not directly influence the development of asthma or wheezing, regulates immune responses analysed.

Key Words: Wheezing. Asthma. Cytokines. Endotoxin. Polymorphisms. 


\section{LISTA DE ILUSTRAÇÕES}

Figura 1. Desenho experimental da casuística de crianças sibilantes e não

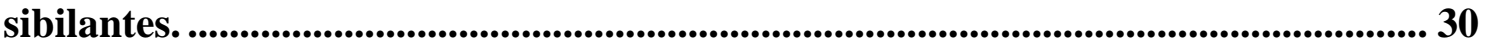

Figura 2. Distribuição de crianças sibilantes e não sibilantes de acordo com a exposição precoce à endotoxina ambiental............................................................ 38

Figura 3. Produção de IL-12 por PBMC de crianças sibilantes e não sibilantes.... 41 Figura 4. Produção de IFN- $\gamma$ por PBMC de crianças sibilantes e não sibilantes. .. 43

Figura 5. Produção de TNF- $\alpha$ por PBMC de crianças sibilantes e não sibilantes.. 45

Figura 6. Produção de IL-17 por PBMC de crianças sibilantes e não sibilantes.... 46

Figura 7. Produção de IL-10 por PBMC de crianças sibilantes e não sibilantes.... 47

Figura 8. Produção de IL-5 por PBMC de crianças sibilantes e não sibilantes...... 48

Figura 9. Produção de IL-4 por PBMC de crianças sibilantes e não sibilantes...... 49

Figura 10. Polimorfismo no gene TLR4 (Asp299Gly) ...............................................5 50

Figura 11 Polimorfismo no gene CD14 (C-159T) ...................................................... 52

Figura 12. Polimorfismo C159C de CD14 associado com maior produção de IFN- $\gamma$

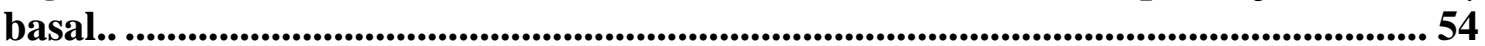

Figura 13. Polimorfismo C159C de CD14 associado com a produção basal de IL-

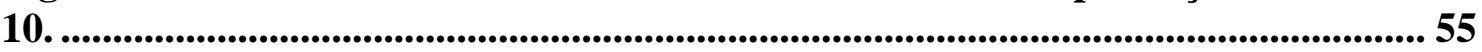

Figura 14. Produção de IL-12p70 por PBMC de crianças asmáticas e não

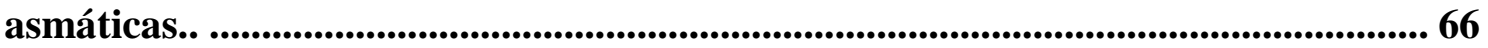

Figura 15. Produção de IFN- $\gamma$ por PBMC de crianças asmáticas e não asmáticas.67 Figura 16. Produção de TNF- $\alpha$ por PBMC de crianças asmáticas e não asmáticas..

Figura 17. Produção de IL-17 por PBMC de crianças asmáticas e não asmáticas. 68 Figura 18. Produção de IL-10 por PBMC de crianças asmáticas e não asmáticas 69 Figura 19. Produção de IL-4 por PBMC de crianças asmáticas e não asmáticas.. 70 Figura 20. Produção de IL-5 por PBMC de crianças asmáticas e não asmáticas. . 70 


\section{LISTA DE TABELAS}

Tabela 1 - Primers utilizados na reação de PCR. .............................................................. 33

Tabela 2 - Condições de amplificação............................................................................... 33

Tabela 3 - Dados clínicos de 86 crianças com alto risco de desenvolvimento de alergia, seguidas durante trinta meses................................................................................... 36

Tabela 4 - Frequência dos genótipos e alelos TLR4 (Asp299Gly) na coorte........... 51

Tabela 5 - Frequência dos genótipos e alelos CD14 na população estudada. .......... 53

Tabela 6 - Polimorfismo C-159T no gene de CD14 associado com sensibilização ao

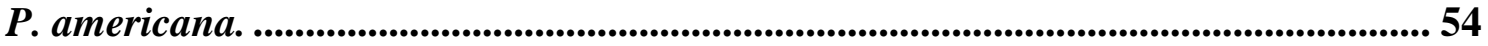

Tabela 7 - Polimorfismo C-159T no gene de CD14 associado com sensibilização a

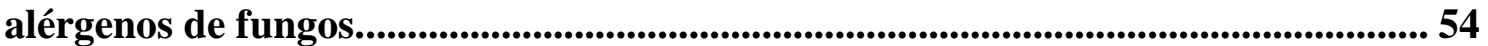

Tabela 8 - Incidência de asma em crianças Sibilantes e Não sibilantes ao final de cinco anos de seguimento clínico. ..................................................................................... 55

Tabela 9 - Dados clínicos de 86 crianças asmáticas e não asmáticas. ..................... 65

Tabela 10 - Polimorfismo de TLR4 em crianças asmáticas leves, moderadas e

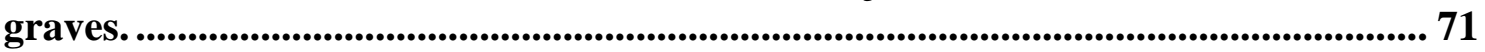

Tabela 11 - Polimorfismo de CD14 em crianças asmáticas leves, moderadas e

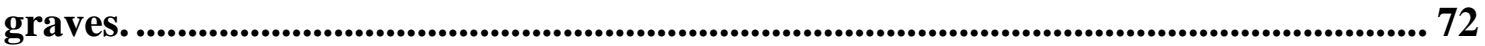

Tabela 12 - Polimorfismo C-159T no gene de CD14 associado com sensibilização a alergenos de fungos....................................................................................................................... 73 


\section{LISTA DE ABREVIATURAS E SIGLAS}

Bla g1 = Blatella germanica

Can $\mathrm{f} 1=$ Canis familiaris

CD14 = do inglês, cluster of differentiation 14

Células NK = do inglês natural killer

DC $=$ do inglês, dendritic cells; em português células dendríticas

Derf 1 = Dermatophagoides farinae

Derp 1 = Dermatophagoides pteronyssinus

DNA = do inglês, desoxirribonucleic acid;, em português ácido desoxirribonucléico

ELISA = do inglês, enzyme linked immunosorbent assay; em português, ensaio imunoenzimático

$\mathrm{EU} / \mathrm{mg}=$ Endotoxina/miligrama

$\mathrm{Fc} \varepsilon \mathrm{RI}=$ receptor 1 da porção $\mathrm{Fc}$ da cadeia $\varepsilon$ da $\operatorname{IgE}$

Fel d1 = Felix domesticus

IFN- $\gamma=$ interferon gama

IL-4 = interleucina 4

IL-5 = interleucina 5

IL-10 $=$ interleucina 10

IL-12 = interleucina 12

IL-17 = interleucina 17

$\mathrm{LAL}=$ do inglês, Limulus amebocyte lysate

LBP = do inglês, LPS biding protein; em português, proteína ligante ao LPS

LPS = lipopolissacarídeo

MHC $=$ do inglês, major histocompatibility complex; em português, complexo principal de histocompatibilidade

Mus $\mathrm{m} 1=$ Mus musculus 
Não-Sib = não sibilantes

PAF $=$ do inglês, platelet-activating factor; em português, fator ativador de plaquetas

PAMPs = do inglês, pathogen-associated molecular patterns; em português, padrões moleculares associados à patógenos

PBMC $=$ do inglês, peripheral blood mononuclear cells; em português, células mononucleares do sangue periférico

Per a1 = Periplaneta americana

$\mathrm{PGD}=$ prostraglandina $\mathrm{D}$

PMA = do inglês, phorbol myristate acetate; em português, acetato de miristato de forbol

PRACTALL $=$ do inglês, practicing allergology or pratical allergy resport

PRRs $=$ do inglês, pattern recognition receptors; em português, receptores que reconhecem padrões de patógenos

Rat $\mathrm{n} 1=$ Rattus norvegicus

RNA = do inglês, ribonucleic acid; em português, ácido ribonucléico

$\mathrm{Sib}=$ sibilantes

T.A. $=$ temperatura ambiente

Th1 = linfócito auxiliar 1

Th2 = linfócitos auxiliar 2

TLR4 = do inglês, toll like receptor 4; em português, receptor do tipo toll 4

TNF- $\alpha=$ do inglês, tumor necrosis factor alpha; em português, fator de necrose tumoral $\alpha$

VCAM-1 = do inglês, vascular cell adhesion molecule-1; em português, molécula vascular para adesão celular

VSR = vírus sincicial respiratório 


\section{SUMÁRIO}

1 INTRODUÇÃ̃ ........................................................................................... 18

1.1 Sibilância na infância ............................................................................................... 18

1.2 Asma na infância e na adolescência .................................................................. 20

1.3 Citocinas envolvidas na resposta imune inata e adaptativa ............................. 22

1.4 Receptores de lipopolissacarídeos .................................................................. 24

1.5 Polimorfismos envolvidos nos fenótipos da sibilância e da asma.................... 25

1.6 Exposição à endotoxina ambiental ....................................................................... 26

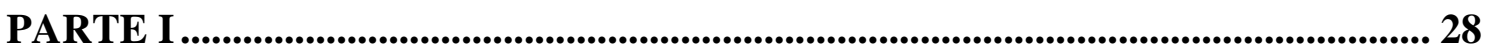

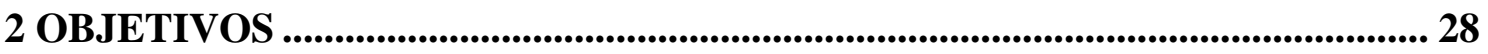

2.1 Objetivos específicos........................................................................................ 28

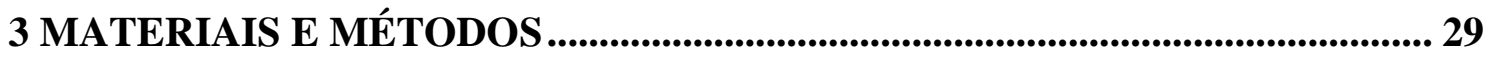

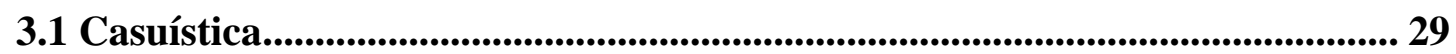

3.2 Teste cutâneo de hipersensibilidade.................................................................. 30

3.3 Coleta, filtragem e homogeneização da poeira domiciliar ............................... 30

3.4 Determinação da concentração de endotoxina ................................................... 31

3.5 Obtenção e cultura de PBMC .............................................................................. 31

3.6 Extração de DNA e Análise de polimorfismo do CD14 (C-159T) e do TLR4 (Asp299Gly) .......................................................................................................................... 32

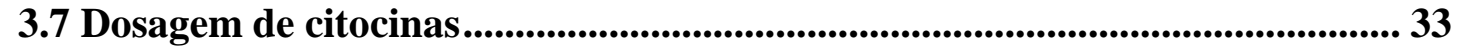

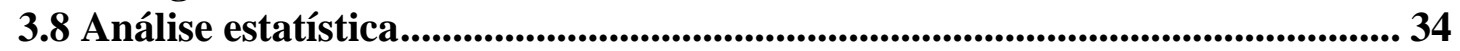

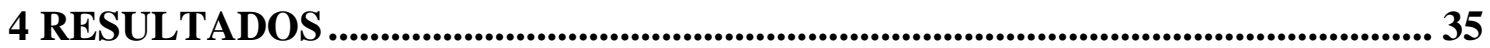

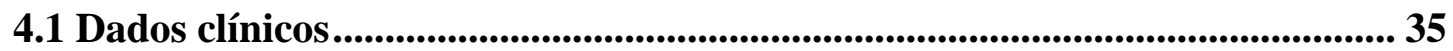

4.2 Exposição precoce à endotoxina ambiental entre crianças sibilantes e não sibilantes ........................................................................................................... 37

4.3 Exposição precoce à endotoxina ambiental e a produção de IL-12p70 e IFN- $\gamma$ por PBMC de crianças sibilantes e não sibilantes, estimuladas com LPS ........... 39

4.4 Exposição precoce à endotoxina ambiental e a produção de TNF- $\alpha$, IL-10, IL-4, IL-5 e IL-17 por PBMC de crianças sibilantes e não sibilantes, estimuladas

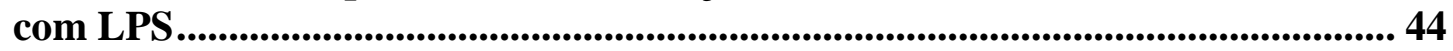

4.5 Prevalência de polimorfismos nos genes de TLR4 e CD14, receptores envolvidos no reconhecimento de LPS ................................................................5 50

4.6 Desenvolvimento da asma em crianças sibilantes................................................. 55

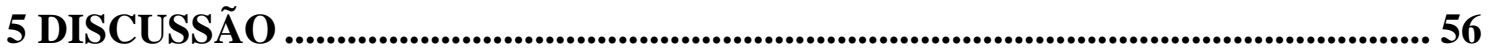

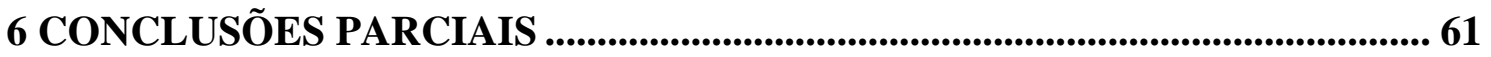

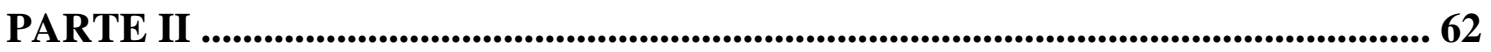

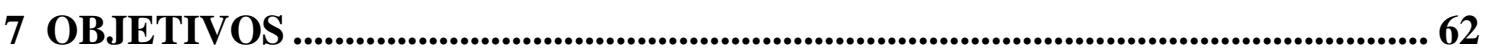

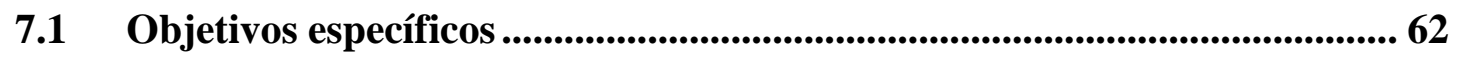

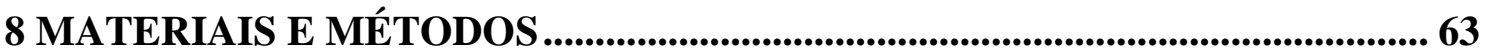

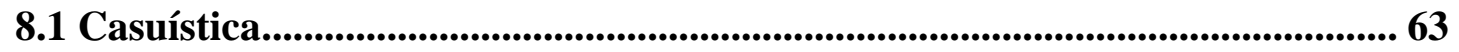

8.2 Teste cutâneo de hipersensibilidade................................................................... 63

8.3 Obtenção e cultura de PBMC ............................................................................ 63 
8.4 Extração de DNA e Análise de Polimorfismos nos genes de CD14 (-159) e TLR4 (299). 64

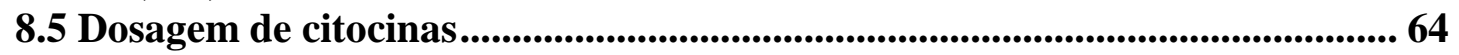

8.6 Análises Estatísticas............................................................................................. 64

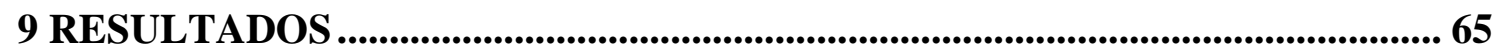

9.1 Dados clínicos........................................................................................................65

9.2 Produção de citocinas por PBMC estimuladas com LPS de crianças asmáticas leves, moderadas e graves e não asmáticas.......................................... 65

9.2.1 Produção de IL-12p70 e IFN-y por PBMC estimuladas com LPS de crianças asmáticas $e$ não asmáticas ..............................................................6 66

9.2.2 Produção de TNF- $\alpha$, IL-17 e IL-10 por PBMC estimuladas com LPS de crianças asmáticas $e$ não asmáticas..................................................................... 67

9.2.3 Produção de IL-4 e IL-5 por PBMC estimuladas com LPS de crianças asmáticas $e$ não asmáticas .................................................................................69

9.3 Polimorfismos nos genes de TLR4 e CD14, receptores envolvidos no reconhecimento de LPS .................................................................................................. 71

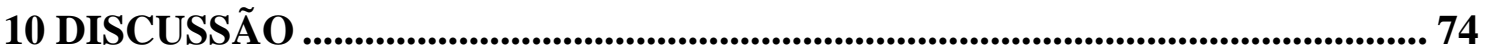

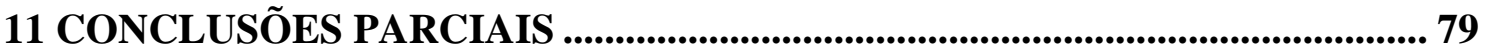

12 CONSIDERAÇAÇÕES FINAIS E PERSPECTIVAS FUTURAS ....................... 80

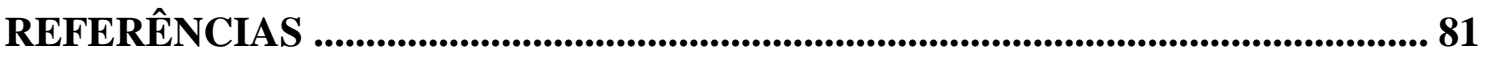

ANEXO A - TERMO DE CONSENTIMENTO LIVRE E ESCLARECIDO -

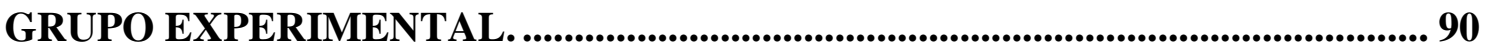

ANEXO B - TERMO DE CONSENTIMENTO LIVRE E ESCLARECIDO (MENORES DE 18 ANOS)................................................................................... 92

ANEXO C - TERMO DE CONSENTIMENTO LIVRE E ESCLARECIDO DA

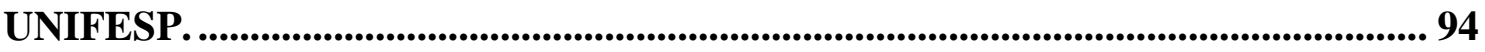

ANEXO D - QUESTIONÁRIOS APLICADOS AOS PAIS/RESPONSÁVEIS DAS CRIANÇAS EM ESTUDO. ...........................................................................96

ANEXO E - PERGUNTAS REALIZADAS PARA CLASSIFICAÇÃO DA ASMA. 99 


\section{INTRODUÇÃO}

\subsection{Sibilância na infância}

A síndrome do lactente sibilante é definida pela presença de sibilância contínua por um mês ou três episódios de chiado num período de seis meses, em crianças menores de dois anos de idade (SOLE, 2008). A sibilância é um sinal clínico inespecífico que traduz a passagem do fluxo turbulento de ar através de vias aéreas estreitas ou parcialmente obstruídas, desencadeando vibrações nas paredes brônquicas (MARTINEZ; HELMS, 1998).

Estudos epidemiológicos demonstram que pelo menos $20 \%$ das crianças menores que dois anos de idade apresentam sibilância transitória, podendo estar relacionada ao tamanho das vias aéreas, à predisposição genética, às infecções virais das vias aéreas superiores, e à exposição passiva ao tabagismo (MARTINEZ et al., 1995). Acredita-se que um terço dos que iniciaram a sibilância antes dos três anos de vida persistirão com os sintomas e, dentre estes, $60 \%$ se manifestarão atópicos aos seis anos de idade (MARTINEZ et al., 1995). Estudo realizado em São Paulo, SP, Brasil, demonstrou que $52 \%$ de crianças com idade de trinta meses apresentaram episódios de sibilância (MALLOL et al., 2005).

Lactentes provenientes de famílias de baixo nível socioeconômico apresentam maior risco quanto à síndrome do lactente sibilante, devido à falta de saneamento e estrutura básica, ao grande número de pessoas na família e que dividem o mesmo leito, além de outras adversidades ambientais (MORGAN; MARTINEZ, 1992). Estudo com essas famílias demonstrou que $80 \%$ das crianças apresentaram episódios de sibilância no primeiro ano de vida e $43 \%$ apresentaram três ou mais crises (BACHARIER et al., 2007).

O estudo de pacientes com sibilância tem grande importância, pois a intensidade dos sintomas durante os dois primeiros anos é fortemente relacionada ao seu prognóstico (MARTINEZ, 2002b; ILLI et al., 2006). Assim, a identificação dos diferentes fenótipos de sibilância e sua expressão futura de asma, tem sido objeto de estudo por muitos grupos de pesquisa (KURUKULAARATCHY et al., 2003; MORGAN et al., 2005; DEVULAPALLI et al., 2008). Contudo, ainda não foram definidos marcadores ou fenótipos indicativos dos indivíduos sibilantes que desenvolverão asma (BACHARIER et al., 2008). 
Segundo o consenso PRACTALL (Practicing Allergology or Pratical Allergy Resport), documento elaborado por especialistas das Academias Européia e Americana de Asma, Alergia e Imunologia (BACHARIER et al., 2008) a sibilância durante a infância foi classificada em quatro padrões distintos:

Sibilância transitória - grupo formado por crianças que apresentam episódios recorrentes de sibilos durante o primeiro ano de vida e mostram aparente remissão, quando ingressam na idade escolar. Cerca de $60 \%$ dessas crianças param de sibilar aos três anos de idade. Estas crianças não apresentam maior incidência de histórico familiar de asma e nem histórico pessoal ou familiar de doenças alérgicas, como a dermatite atópica. Estudos epidemiológicos demonstram que tais crianças tendem a ter sintomas de sibilância quase que exclusivamente durante as infecções virais (DUFF et al., 1993).

Sibilância não-atópica - grupo formado por 30 a $40 \%$ das crianças que sibilam durante os três primeiros anos de vida e que continuam a apresentar sibilos aos seis anos de idade. Apenas metade dessas crianças são sensibilizadas contra aeroalérgenos. Esta forma de sibilância é desencadeada principalmente por vírus, tendendo a desaparecer com o avanço da idade (BACHARIER et al., 2008)

Asma persistente - sibilância associada a manifestações clínicas de atopia, eczema, rinite, conjuntivite, alergia alimentar, sensibilização comprovada pela presença de IgE e pais asmáticos (RHODES et al., 2002; DE MARCO et al., 2004);

Sibilância intermitente grave - episódios pouco frequentes de sibilância aguda associados a poucos sintomas fora dos quadros agudos, e com a presença de características de atopia (eczema, sensibilização alérgica e eosinofilia) (BACHARIER et al., 2007).

Como mostrado na classificação, existe uma associação importante entre as infecções virais e sibilância em lactentes. Mais de $70 \%$ dos episódios de sibilância no primeiro ano de vida estão relacionados a infecções virais respiratórias (WRIGHT et al., 1989). Nos menores de dois anos, o agente causal mais comum é o vírus sincicial respiratório (VSR), um retrovírus paramixovírus, sendo também o maior causador de bronquiolite viral. O mecanismo pelo qual o VSR desencadeia a sibilância está associado à resposta de células $\mathrm{T}$ caracterizada principalmente pela produção de citocinas Th2 (linfócito T helper 2), a mesma resposta observada durante os episódios de asma (ROMAN et al., 1997; TREGONING; SCHWARZE, 2010).

A natureza desses distúrbios de desenvolvimento de chiado ainda não é totalmente compreendida. Sabe-se que as doenças alérgicas podem ser atribuídas a um 
desequilíbrio entre os padrões Th1 (linfócitos T helper 1) e Th2 de liberação de citocinas, principalmente durante os primeiros anos de vida (DE MELLO et al., 2009). Este desequilíbrio pode se somar a fatores ambientais, como exposição à endotoxina, ou fatores fisiológicos, como aumento da produção de anticorpos, principalmente IgE (relacionada à maior resposta $\mathrm{Th} 2$ ) e aumento da atividade de eosinófilos (WILSON, 2003). Estas características são consideradas essenciais para o estabelecimento de doenças alérgicas e agravamento da sibilância.

\subsection{Asma na infância e na adolescência}

Segundo a organização mundial de saúde estima-se que 300 milhões de pessoas são acometidas pela asma em todo mundo (LAI et al., 2009), sendo que 60\% são crianças, e o Brasil é o oitavo país em prevalência dessa patologia (BUNNAG et al., 2009). Esses estudos epidemiológicos sugerem o aumento da prevalência da asma no mundo desenvolvido nas últimas décadas, especialmente em crianças e adolescentes (SOLE et al., 2001; SOLE et al., 2006), sendo as causas desse aumento ainda não esclarecidas completamente.

A asma é caracterizada pela obstrução, hiper-responsividade brônquica e inflamação das vias áreas (MARTINEZ, 2002a), podendo ser definida também como uma doença inflamatória causada por repetidas reações de hipersensibilidade imediata e tardia no pulmão (PICCINNI et al., 2000). A hipersensibilidade imediata é desencadeada quando há ligação cruzada de um antígeno multivalente às moléculas de IgE previamente ligadas ao receptor FceRI presente na membrana de mastócitos e basófilos, ativando estas células (NADLER et al., 2000). Este processo estimula a produção de aminas biogênicas, como histamina, e mediadores lipídicos, tais como PAF (fator ativador de plaquetas) e $\mathrm{PGD}_{2}$ (prostaglandina $\mathrm{D} 2$ ), que causam aumento da permeabilidade vascular e bronco-constrição, e estimulam a produção de citocinas próinflamatórias, como fator de necrose tumoral alfa (TNF- $\alpha$ ) (WEDEMEYER et al., 2000).

A hipersensibilidade imediata conta com uma fase tardia, que consiste no acúmulo de leucócitos inflamatórios, incluindo basófilos, eosinófilos, células Th2 e neutrófilos. A inflamação se inicia dentro de 4 a 8 horas e pode persistir por pelo menos 12 a 24 horas (PRADALIER, 1993). Além dos mastócitos e basófilos, os eosinófilos também degranulam liberando proteínas tóxicas que podem lesionar o tecido normal 
(ROTHENBERG; HOGAN, 2006). Diferentemente dos primeiros, os eosinófilos são ativados através da IL-5 (interleucina 5), produzida por células Th2. Esta citocina aumenta a capacidade dos eosinófilos em liberar o conteúdo de seus grânulos, além de recrutá-los para locais inflamatórios da reação de fase tardia, contribuindo para os processos patológicos das doenças alérgicas (SAMPSON, 2001).

As células Th2 têm um papel importante na hipersensibilidade imediata, principalmente em indivíduos asmáticos com maior número de células $\mathrm{T}$ alérgenoespecíficas secretoras de IL-4 (interleucina 4) e IL-5 (KAY, 1996). Seguindo predisposição genética, os linfócitos T naive de indivíduos asmáticos diferenciam-se em linfócitos Th2, após a apresentação dos alérgenos pelas células dendríticas (HOLT, 2002). Estas células diferenciadas produzem citocinas, tais como IL-4, IL-5 e IL-13 (interleucina 13). Dentre estas citocinas, a IL-4 desempenha um papel chave no quadro asmático, pois está envolvida diretamente com a troca de classe das imunoglobulinas das células B para o isótipo IgE, além de estimular a diferenciação dos linfócitos T naive em Th2 e funcionar como um fator de crescimento autócrino para células Th2 diferenciadas (LEE et al., 2001). A IL-4 ainda inibe o desenvolvimento das células Th1 (WANG et al., 2006) e, juntamente com a IL-13, influencia a inflamação alérgica. Estas citocinas promovem fibrose como parte de reparação tecidual dos estados inflamatórios crônicos, estimulam a produção de muco pelas células epiteliais pulmonares, induzem síntese de IgE, induzem a expressão de moléculas de adesão endotelial, como VCAM-1 (vascular cell adhesion molecule-1) e quimiocinas, as quais medeiam a diapedese de granulócitos e monócitos. Portanto, a produção e participação dessas e outras citocinas contribuem para o desenvolvimento e estabelecimento da patogenia da asma (DOUCET et al., 1998; WANG et al., 2006). 


\subsection{Citocinas envolvidas na resposta imune inata e adaptativa}

As citocinas são componentes chave nas respostas alérgicas, sibilância e asma. Além das já descritas anteriormente, outras citocinas que merecem destaque nesses quadros são as do padrão Th1, IL-12 (interleucina 12) e IFN- $\gamma$ (interferon gama), do padrão regulatório, como a IL-10 (interleucina 10), e inflamatório, IL-17 (interleucina 17) e TNF- $\alpha$.

A IL-12 e o IFN- $\gamma$ têm sua importância classicamente descrita nas respostas celulares a bactérias intracelulares, além de estarem envolvidas na resposta imune antiviral (TRINCHIERI, 2003) No caso de crianças sibilantes infectadas por VSR, essas citocinas também desencadeiam a resposta imune de padrão Th1 (GERN, 2010). A IL12 é a principal mediadora entre a resposta imune inata e a adaptativa. Foi identificada originalmente como ativadora da função citotóxica das células natural killers (NK), mas sua ação mais importante é estimular a produção de IFN- $\gamma$ pelas células T e células NK, além de diferenciar células $\mathrm{T}$ naive para subpopulação Th1 (MARTINEZ; TRINCHIERI, 2001). O IFN- $\gamma$ produzido pelas células Th1 também estimula a produção de IL-12 (BOEHM et al., 1997) por células dendríticas e macrófagos ativados, ativando o que é conhecido como eixo IL-12/IFN- $\gamma$.

Durante as reações da imunidade inata, a IL-12 é produzida em resposta à sinalização por toll-like receptors (TLR) induzida por muitos estímulos microbianos, incluindo lipopolissacarídeos (LPS) e mediante a ligação entre o ligante do CD40 nas células T com o CD40 nos macrófagos e células dendríticas (SCHULZ et al., 2000). O IFN- $\gamma$ além de ativar os macrófagos e inibir a proliferação de células Th2, age nas células B para promover a troca para subclasses de $\operatorname{IgG}$ e para inibir a troca para isótipos dependentes de IL-4, tais como IgE e IgG1 (BOEHM et al., 1997). A exposição a produtos bacterianos, como a endotoxina, no contex to da ativação do eixo IL-12/ IFN$\gamma$ (KOCH et al., 2007), possui um papel descrito como importante na proteção contra a alergia, pois gera resposta Th1, reduzindo a produção de citocinas Th2, tais como IL-4 e IL-5 (EDER; VON MUTIUS, 2004).

Não só as citocinas responsáveis pela polarização da resposta de linfócitos T para Th1 ou Th2 são importantes no quadro de sibilância e asma, mas também as que controlam as resposta imunes. Existem vários tipos celulares com perfil regulatório, entre eles, as células produtoras de IL-10 (interleucina 10). Esta citocina é produzida principalmente por macrófagos ativados e células T reguladoras, sendo que sua função é 
inibir a produção de IL-12, expressão de moléculas co-estimuladoras e de moléculas codificadas pelo MHC de classe II presentes em macrófagos e células dendríticas. Portanto, a IL-10 está envolvida no controle das reações da imunidade inata e da imunidade mediada por células. O papel da IL-10 na regulação da inflamação alérgica deve-se a sua habilidade de induzir tolerância nas células T para alérgenos (ENK et al., 1993; ADACHI et al., 1999). A sobrevida de eosinófilos é também inibida pela IL-10 (PUNNONEN et al., 1993).

Assim como a regulação dos processos inflamatórios na sibilância e asma é importante, a potencialização desses processos é um ponto chave nessas patologias. Nesse contexto, encontram-se as células T produtoras de IL-17. Essa citocina consiste em uma família de seis citocinas estruturalmente relacionadas (IL-17A - F), algumas das quais promovem dano tecidual em doenças de hipersensibilidade e outras (AGACHE et al., 2010). A diferenciação e maturação das Th17 são dependentes de TGF- $\beta$, IL-23 (interleucina 23) e citocinas produzidas durante a resposta imune inata, como IL-6 e IL-17A. As IL-17A e F estimulam a produção de IL-1 (interleucina 1) e TNF- $\alpha$, além de várias quimiocinas, as quais promovem o recrutamento de neutrófilos (PAPPU et al., 2010). Essa citocina é responsável pela inflamação em diversos modelos, sendo importante na asma e doenças auto-imunes (AGACHE et al., 2010; TANASESCU et al., 2010).

Outra citocina importante é o TNF- $\alpha$, principal mediador da resposta inflamatória aguda, produzido principalmente por fagócitos mononucleares ativados, embora células T estimuladas por antígenos, células NK e mastócitos também possam secretar essa proteína (WEDEMEYER; GALLI, 2000). O TNF- $\alpha$ atua estimulando a resposta de fase aguda com a produção de proteína $\mathrm{C}$ reativa. Funciona como potente quimiotático para neutrófilos, estimulando a fagocitose e a produção de outras citocinas inflamatórias, como IL-1 e IL-6, além de mediadores lipídicos. Níveis elevados dessa citocina foram detectados no escarro, no lavado broncoalveolar e em biópsias de pacientes asmáticos (CEMBRZYNSKA-NOWAK et al., 1993). A importância do TNF$\alpha$ como uma citocina multifatorial na asma grave tem sido reforçada pela constatação de um aumento de mais de trinta vezes na sua expressão gênica nas vias aéreas (KROUWELS, 2007). Esta citocina contribui de forma substancial na patogênese da inflamação crônica das vias aéreas, incluindo remodelamento brônquico (BABU et al., 2004). Além disso, esta citocina tem um potente efeito direto no músculo liso determinando hiper-responsividade das vias aéreas (BERRY et al., 2007). Um dos 
estímulos mais potentes para desencadear a produção de TNF- $\alpha$ por macrófagos é o LPS, através de sua ligação ao complexo de CD14/TLR4/MD2 (IWASAKI; MEDZHITOV, 2010).

\subsection{Receptores de lipopolissacarídeos}

Antes da produção de citocinas e diferenciação das células, os estímulos externos, como a presença de patógenos ou mesmo de suas moléculas, são importantes para desenvolvimento das respostas imunes. A identificação dos patógenos pelas células da imunidade inata ocorre principalmente pelo reconhecimento dos chamados padrões moleculares associados à patógenos (PAMPs) (AKIRA; HEMMI, 2003). Os receptores para PAMPs são chamados receptores de reconhecimento de padrões (do inglês, PRRs Pattern recognition receptors). Os TLR constituem um dos mais, se não o mais, importante grupo dentre os PRRs (MEDZHITOV; JANEWAY, 1997; MEDZHITOV et al., 1997). A primeira proteína dessa família foi identificada em Drosophila, na qual está envolvida no estabelecimento do eixo dorsoventral durante a embriogênese, mas posteriormente foi descoberto que a proteína Toll também media respostas a microrganismos (KOPP; MEDZHITOV, 1999). Atualmente em camundongos são conhecidos 11 TLRs, sendo denominados TLR1 ao TLR11 e em humanos 10 TLRs. Todos esses receptores contêm um domínio de homologia ao receptor toll/IL-1 (TIR) em suas regiões citoplasmáticas, o qual é essencial para ativação de sua via de sinalização (BARTON; MEDZHITOV, 2003).

Os sítios de ligação nos TLR para os ligantes microbianos estão sendo estudados por cristalografia de raios $\mathrm{X}$ e análises de mutações. Até agora, a base estrutural para as diferentes especificidades do TLR permanece desconhecida (FOSTER; MEDZHITOV, 2009). A sinalização pelo TLR exige sua dimerização na membrana celular, o que envolve dimerização de duas proteínas TLR idênticas ou diferentes. A especificidade dos TLR também é influenciada por várias moléculas acessórias. Isto é mais completamente compreendido em relação ao TLR4 e seu ligante LPS (MCGETTRICK; O'NEILL, 2010). O LPS se liga primeiro à proteína ligadora de LPS (LBP) solúvel no sangue ou líquido extracelular, e este complexo serve para facilitar a ligação do LPS ao CD14, o qual existe como uma proteína plasmática solúvel e uma proteína de membrana, ligada a glicofosfatidilinositol na maioria das células, exceto no endotélio. Uma vez que LPS se liga ao CD14, LBP se dissocia, e o complexo 
LPS-CD14 se associa fisicamente ao TLR4 (FINBERG et al., 2004). Uma proteína acessória extracelular adicional chamada MD2 também se liga ao complexo com CD14. LPS, CD14 e MD2 são todas requeridas para sinalização eficiente induzida por LPS, mas ainda não está claro se é necessária interação física direta de LPS com TLR4 (ERRIDGE et al., 2008).

\subsection{Polimorfismos envolvidos nos fenótipos da sibilância e da asma}

Embora os TLR sejam mediadores da resposta imune a patógenos, não é compreendida a influência da sua variabilidade genética na suscetibilidade a infecções microbianas em humanos. O polimorfismo Asp299Gly no gene codificante do TLR4, atenua a sinalização por este receptor e foi associado a várias doenças (REZAZADEH et al., 2006; ROHDE et al., 2006), inclusive com o desenvolvimento da asma (FAGERAS BOTTCHER et al., 2004). No entanto, outros estudos mostram que este polimorfismo não está associado a doenças alérgicas (SMIT et al., 2007).

Também foi descrito um polimorfismo na região promotora do gene codificante do CD14, caracterizado pela mudança de um nucleotídeo citosina por uma timina na posição -159 , nesta posição encontra-se o sítio de iniciação da transcrição. Este polimorfismo foi associado a diversas doenças inclusive com o desenvolvimento de asma (BERNSTEIN et al., 2006). Além disso, estudos demonstram que esse polimorfismo está associado à diminuição de CD14 solúvel (BALDINI et al., 1999) e ao aumento dos níveis plasmáticos de IgE em pacientes atópicos (BUCKOVA et al., 2006).

Há mais de um século aceita-se que a genética tenha uma participação importante na determinação da sibilância e da asma. A asma tem vários padrões de manifestações clínicas, possivelmente secundários à interferência não de um gene em especial, mas de vários genes, em diferentes intensidades, associada a fatores ambientais. Vários foram os polimorfismos genéticos estudados até o momento associados à asma e a sibilância, além daqueles descritos nos genes de CD14 (SACKESEN et al., 2010) e TLR4 (FAGERAS BOTTCHER et al., 2004). Mais genes podem estar envolvidos, como nos genes de TLR7 e 8, TNF- $\alpha$ (GUPTA et al., 2005), IFN- $\gamma$, IL-10, TGF- $\beta 1$, IL-6 e outros (MOVAHEDI et al., 2008). 


\subsection{Exposição à endotoxina ambiental}

O LPS é uma estrutura comum a todas as bactérias gram-negativas e como tal é um PAMP. É constituído por três regiões distintas, a hidrofóbica - componente lipídico A (endotoxina, a molécula bioativa), um núcleo pequeno de oligossacarídeos e um antígeno-O polissacarídeo (cuja presença ou ausência determina a morfologia da colônia) (BEUTLER; RIETSCHEL, 2003). As endotoxinas são moléculas amfipáticas, apresentando moléculas de polissacarídeo e moléculas lipídicas. Em humanos, infecções sistêmicas com bactérias gram-negativas podem resultar em choque endotóxico, com falência de múltiplos órgãos, uma resposta extrema a exposição à endotoxina (BEUTLER; RIETSCHEL, 2003).

Em 1964 foi descrito pela primeira vez a presença de endotoxina na poeira doméstica, sendo seus efeitos sobre o sistema respiratório documentados, em trabalhadores de algodão, que relataram aperto no peito e febre, juntamente com alterações na função pulmonar, incluindo uma redução na transferência de gás, que levou a sugestões de que as exposições foram importantes no desenvolvimento dos sintomas (BEUTLER; RIETSCHEL, 2003). Exposição à endotoxina é comum em ambientes de trabalho e de casas, tendo como suas principais fontes animais de estimação, umidificadores, dentre outros. Estudos na década de 90 caracterizaram respostas pulmonares, incluindo a inflamação do pulmão e aumento na produção de citocinas, após inalação de endotoxina e poeiras orgânicas contendo endotoxina por humanos (MICHEL et al., 1991) Além desses, outros estudos mostraram que endotoxinas inaladas provocam ativação celular e liberação de citocinas por macrófagos e outras células mielóides através do contexto CD14/TLR4/MD2 (BEUTLER; RIETSCHEL, 2003). Esta resposta a inalação de endotoxina pode variar entre os indivíduos, pela genética ou pelo grau desenvolvido de tolerância ao LPS.

Uma série de estudos epidemiológicos tem chamado atenção para exposição de endotoxina e seu papel na asma. (MICHEL, 2001) investigaram a presenca de endotoxina na poeira de casas de pacientes com rinite crônica estável ou asma e observaram uma associação significativa entre a concentração da endotoxina na poeira de pisos e colchões, mas não de alérgenos, com a gravidade da asma e uso de medicação para asma. Estudos da Baviera, Canadá e Suécia demonstraram que famílias que moram em zonas rurais desenvolvem menos alergia e asma alérgica (SIMPSON et al., 2006). 
Este efeito protetor (a hipótese da higiene) é suportado pelos estudos que demonstram uma mudança de um fenótipo alérgico com a exposição precoce a endotoxina (SIMPSON et al., 2006). Entretanto, estudos da Austrália, Europa, Nova Zelândia e Estados Unidos da América demonstram ter as mesmas ou maiores taxas de asma (ou seja, sem efeito protetor), entre crianças que moram em áreas rurais quando comparadas àquelas que moram em zonas urbanas (SIMPSON et al., 2006). Diferentemente, o papel da endotoxina como um fator de risco para asma e sibilância tem sido demonstrado em estudos de coorte urbana, que constataram que a maior exposição à endotoxina ambiental esteve associada com a maior prevalência de sibilância (SIMPSON; MARTINEZ, 2010).

Mesmo com o constante avanço no esclarecimento dos aspectos dessas patogenias, existem inúmeras controvérsias no conhecimento sobre exposição à endotoxina, background genético, ativação celular, liberação de mediadores, quando relacionados ao desenvolvimento da sibilância e da asma. Tais divergências são ainda maiores em nosso país, com características demográficas, sócio-econômicas e climáticas muito variadas e peculiares.

Levando em consideração essas controvérsias e o que está bem estabelecido sobre o LPS e suas vias de reconhecimento e sinalização, buscamos nesse trabalho investigar a exposição à endotoxina ambiental, o papel do LPS na ativação de leucócitos do sangue periférico, polimorfismos genéticos e o desenvolvimento dos fenótipos de sibilância e asma na infância. 


\section{PARTE I}

\section{OBJETIVOS}

Investigar as relações entre exposição à endotoxina ambiental, o papel do LPS em ativar leucócitos do sangue periférico, prevalência de polimorfismos genéticos e o desenvolvimento dos fenótipos de sibilância e asma na infância.

\subsection{Objetivos específicos}

A) Avaliar a concentração de endotoxina na poeira de pisos das casas das crianças em estudo durante os primeiros seis meses de vida;

B) Realizar o acompanhamento clínico do grupo desde o nascimento até os cinco anos de idade, avaliando a incidência de infecções de repetição, sibilância e sinais e sintomas relacionados com diátese atópica;

C) Avaliar a sensibilização atópica das crianças estudadas por meio do teste cutâneo de hipersensibilidade imediata (prick test);

D) Avaliar a produção de citocinas (TNF- $\alpha$, IL-10, IL-12, IFN- $\gamma$, IL-4, IL-5 e IL17) liberadas por PBMC de crianças sibilantes e não sibilantes mediante a estimulação com LPS;

E) Investigar a prevalência dos polimorfismos nos genes de CD14 (T-159C) e TLR4 (Asp299Gly) em crianças sibilantes e não sibilantes;

F) Analisar as possíveis associações entre esses parâmetros. 


\section{MATERIAIS E MÉTODOS}

\subsection{Casuística}

Oitenta e seis crianças com alto risco para o desenvolvimento de doenças alérgicas (pais atópicos), residentes na comunidade de Paraisópolis (área de baixa renda), São Paulo, SP, Brasil, foram selecionadas e seguidas desde o nascimento até sessenta meses de idade. Nos primeiros seis meses de vida, foi coletada a poeira domiciliar do piso para determinar a concentração de endotoxina. Aos doze meses de vida, foi aplicado um questionário sobre a saúde das crianças (ANEXO D) e após trinta meses estas foram clinicamente avaliadas e classificadas como crianças sibilantes ou não sibilantes. Crianças sibilantes foram definidas como aqueles que apresentaram três ou mais episódios de chiado, necessitando de tratamento com antagonista $\beta_{2}$. Neste mesmo período foi realizado o teste cutâneo de hipersensibilidade (prick test) e coletado o sangue periférico para exames laboratoriais no Laboratório de Imunologia Humana do Instituto de Ciências Biomédicas da Universidade de São Paulo. Aos sessenta meses de vida dessas crianças foi realizada uma nova avaliação clínica e estas foram classificadas como asmáticas e não asmáticas. Foram utilizados os critérios do Global Initiative for Asthma (GINA) para o diagnóstico clínico de asma (www.ginasthma.com). Para melhor entendimento dos procedimentos realizados fizemos o desenho experimental da casuística (Figura 1).

Os pais ou responsáveis legais das crianças deram seu consentimento informado, e todos os procedimentos aqui descritos não ultrapassaram os limites de risco mínimo de acordo com a regulamentação da Convenção de Helsinki para pesquisa com seres humanos e do Conselho Nacional de Saúde. As cópias da aprovação do projeto de pesquisa pelas Comissões de Ética em Pesquisa do ICB-USP e da UNIFESP encontram-se nos ANEXOS A, B e C. 


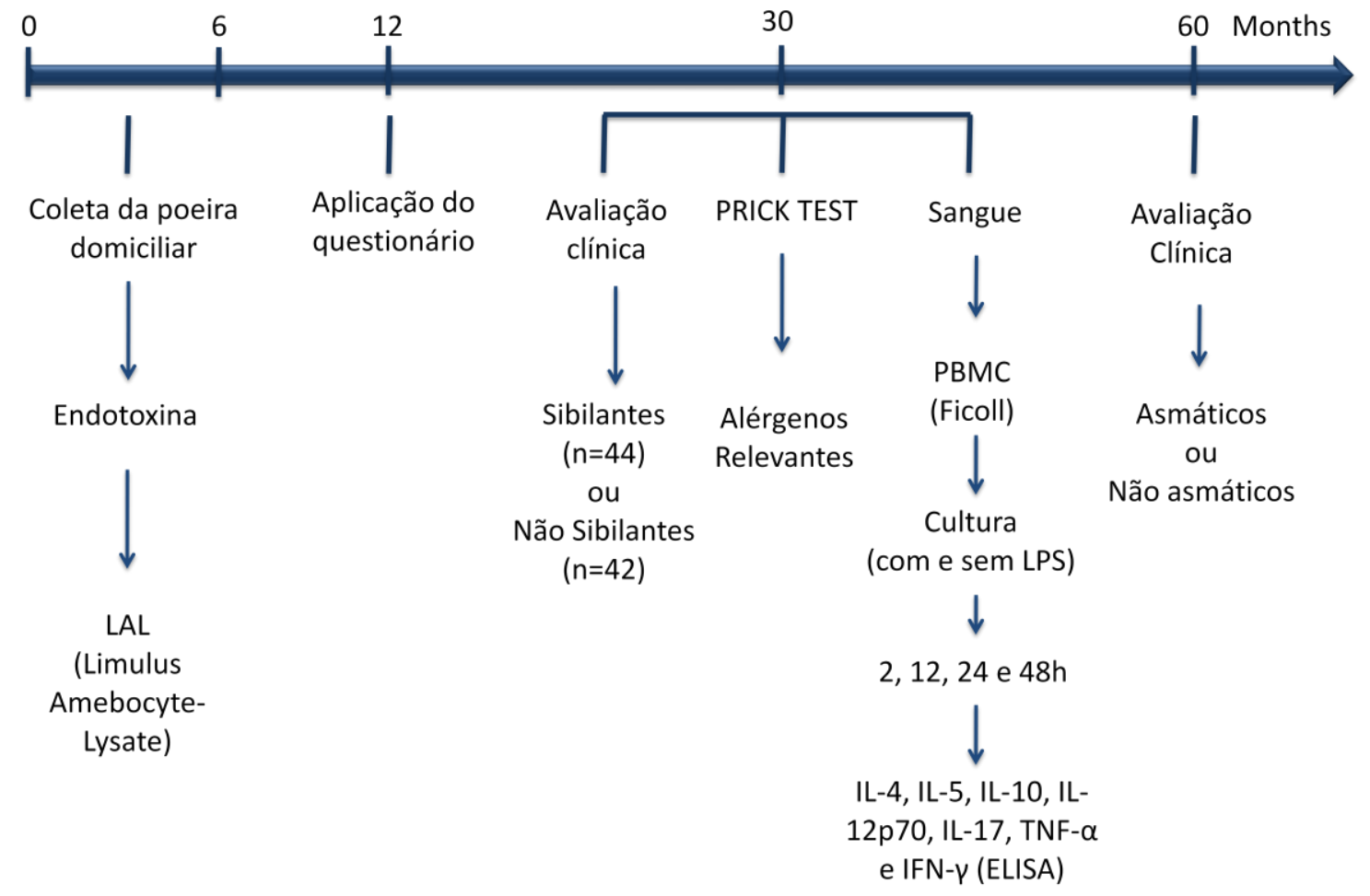

Figura 1. Desenho experimental da casuística de crianças sibilantes e não sibilantes.

\subsection{Teste cutâneo de hipersensibilidade}

Foi avaliada a sensibilização atópica por meio do teste de hipersensibilidade imediata (prick test), realizada com antígenos de Dermatophagoides pteronyssinus, $D$. farinae, Blomia tropicalis, Blatella germanica, Periplaneta americana, Canis familiaris (antígenos de cães), Felix domesticus (antígenos de gato), Mus musculus (antígenos de camundongos), Rattus norvegicus (antígenos de ratos), fungos (mistura de antígenos), pólen (mistura de antígenos), leite de vaca, ovo, e soja. Para controle negativo foi utilizado solução salina tamponada, e como controle positivo histamina. Todas as aplicações foram feitas na região do antebraço, e após 15 minutos, realizada a leitura com auxílio de régua ou paquímetro, sendo considerada positiva a reação cuja pápula apresentou tamanho igual ou superior a três $3 \mathrm{~mm}$ de diâmetro.

\subsection{Coleta, filtragem e homogeneização da poeira domiciliar}

As amostras de poeira foram coletadas da superfície do piso dos domicílios. Para tanto foi utilizado um aspirador em pó manual (Electrolux, Brasil) equipado com 
um coletor de algodão e poliéster adaptado na extremidade do tubo aspirador e um filtro de papel. Cada $1 \mathrm{~m}^{2}$ de superfície foi aspirado durante 2 minutos. Em seguida, o filtro de papel contendo as amostras foi colocado em saco plástico esterilizado. No final de cada coleta, a ponta do aspirador foi limpa, com água e álcool. O armazenamento das amostras foi realizado em freezer a $-80^{\circ} \mathrm{C}$. As partículas de poeira foram separadas do filtro de papel no interior do fluxo laminar, utilizando cureta estéril. Em seguida, foram passadas por uma peneira estéril com poros de 300 a 355 micrômetros de diâmetro (Endecotts Ltd, London, UK), com a finalidade de remover fibras e partículas maiores, obter um pó homogêneo e pesá-lo. Pretendíamos dessa maneira, obter partículas de seis a $300 \mu \mathrm{m}$ de tamanho. Os extratos da poeira foram armazenados em tubos cônicos de polipropileno estéreis (BD System Franklin Lakes, NJ, USA) para posterior quantificação de endotoxina.

\subsection{Determinação da concentração de endotoxina}

Para análises da endotoxina foi utilizada a técnica do Limulus Amebocyte Lysate (LAL), um método cinético turbidimétrico, que utiliza um extrato aquoso derivado de Limulus amebocytes. As amostras foram preparadas misturando-se $10 \mathrm{mg}$ de poeira com $400 \mu \mathrm{l}$ de água destilada estéril apirogênica, em tubo cônico de polipropileno estéril (BD System Franklin Lakes, NJ, USA), agitando a mistura no vórtex durante cinco minutos, à temperatura ambiente (T.A.), com subsequente decantação por uma hora. Cada amostra em suspensão, foi diluída nas proporções de 1:40.000 a 1:160.000 vezes para realização da leitura. As análises foram realizadas em duplicata e quando o rendimento na recuperação da amostra foi menor que $45 \%$, a análise foi repetida com a suspensão mais concentrada. No rendimento superior a $200 \%$, a análise foi repetida com a diluição maior. Os resultados da concentração de endotoxina foram expressos como Endotoxina/miligrama (EU/mg) (SIMPSON et al., 2006).

\subsection{Obtenção e cultura de PBMC}

Um volume de 10-15 ml de sangue periférico das crianças foi coletado em heparina e diluído em PBS (Solução Salina Fosfatada) estéril na proporção de 1:1 e adicionado ao gradiente de densidade Ficoll-Hipaque 1077 (SIGMA, CA, EUA) no 
mesmo volume de sangue coletado. Após a centrifugação a 900 g por vinte minutos, a fase contendo as PBMC foi coletada e transferida para um tubo cônico de polipropileno, estéril (BD System Franklin Lakes, NJ, USA), sendo lavadas em PBS estéril. As PBMC foram cultivadas em meio RPMI 1640 (SIGMA, CA, EUA) suplementado com 10\% de soro fetal bovino (SFB; SIGMA, CA, EUA) inativado pelo calor, $2 \mathrm{mM}$ L-glutamina (SIGMA, CA, EUA), $100 \mathrm{U} / \mathrm{ml}$ penicilina (SIGMA, CA, EUA), 10mg/ml estreptomicina (SIGMA, CA, EUA) e 50 mM 2-Mercapto-Etanol (SIGMA, CA, EUA) e incubadas à $37^{\circ} \mathrm{C}$ em atmosfera saturada com $5 \% \mathrm{CO}_{2}$, com ou sem a estimulação de LPS (10 $\mu \mathrm{g} / \mathrm{ml}$; SIGMA, CA, EUA). O sobrenadante destas culturas foi colhido em duas, doze, 24 e 48 horas e o controle sem estímulo após as 48 horas. Os sobrenadantes foram congelados à $-80{ }^{\circ} \mathrm{C}$ para posterior dosagem de citocinas.

\subsection{Extração de DNA e Análise de polimorfismo do CD14 (C-159T) e do}

\section{TLR4 (Asp299Gly)}

A extração de DNA foi realizada utilizando o Kit Genomic DNA Purification (Promega). Após sua extração foi determinada a concentração e grau de pureza da cada amostra pelo aparelho NanoDrop 1000 (Thermo Scientific, DE, EUA). As amplificações foram realizadas no termociclador GeneAmp PCR Sytem 9700 (PE Applied Biosystems, Foster City, CA, EUA) num volume de $25 \mu \mathrm{l}$ em tubos contendo 20 ng de DNA genômico, 1,5 U Taq polymerase (Invitrogen Life Technologies, Carlsbad, CA, EUA), tampão da enzima $[10$ mM Tris- $\mathrm{HCl}(\mathrm{pH} 8,3)$ e 50 mM KCl; Invitrogen]; 1,5 mM MgCl2; 0,2 mmol de cada unidade de dNTP (Invitrogen); 30 pmol de cada oligonucleotídeo e 12,5 pmol de primers forward e reverse (Tabela 1). As condições de amplificação estão descritas na Tabela 2. Dez microlitros do produto da reação em cadeia da polimerase (PCR) foram incubados overnight com 0,5 $\mathrm{U}$ da enzima de restrição AVA II endonuclease (New England Biolabs, Beverly, MA, EUA) para a análise do polimorfismo de CD14 e Nco I (New England Biolabs, Beverly, MA, EUA) para a análise do polimorfismo de TLR4 num volume final de $20 \mu \mathrm{L}$ a $37^{\circ} \mathrm{C}$. As amostras foram submetidas à eletroforese em gel de agarose (Invitrogen) a 4\%, $70 \mathrm{~V}$, a T.A., durante $1 \mathrm{~h}$ e $30 \mathrm{~min}$. As bandas foram visualizadas após coloração com brometo de etídeo (Invitrogen) e as imagens obtidas por fotodocumentador (GE). 
Tabela 1 - Primers utilizados na reação de PCR.

\begin{tabular}{ll}
\hline & \multicolumn{1}{c}{ PRIMERS } \\
\hline TLR4 Forward & GATTAGCATACTTAGACTACTACCTCGATG \\
TLR4 Reverse & GTGGGAATGCTTTTCAGAAGTTGATC \\
CD14 Forward & GTGCCAACAGATGAGGTTCAC \\
CD14 Reverse & GCCTCTGACAGTTTAGTAATC \\
\hline
\end{tabular}

Tabela 2 - Condições de amplificação.

\begin{tabular}{ccc}
\hline & CD14 & TLR4 \\
\hline T. Inicial & $95^{\circ} \mathrm{C} / 5 \mathrm{~min}$ & $95^{\circ} \mathrm{C} / 5 \mathrm{~min}$ \\
30 Ciclos & $95^{\circ} \mathrm{C} / 1 \mathrm{~min}$ & $95^{\circ} \mathrm{C} / 1 \mathrm{~min}$ \\
& $58^{\circ} \mathrm{C} / 1 \mathrm{~min}$ & $62{ }^{\circ} \mathrm{C} / 1 \mathrm{~min}$ \\
& $72^{\circ} \mathrm{C} / 1 \mathrm{~min}$ & $72{ }^{\circ} \mathrm{C} / 1 \mathrm{~min}$ \\
T. Final & $72^{\circ} \mathrm{C} / 7 \mathrm{~min}$ & $72^{\circ} \mathrm{C} / 7 \mathrm{~min}$ \\
\hline
\end{tabular}

\subsection{Dosagem de citocinas}

A liberação de citocinas (IFN- $\gamma$, IL-12, IL-4, IL-5, IL-10, TNF- $\alpha$ e IL-17) foi quantificada por meio de ELISA (do inglês, Enzyme-linked immunosorbent assay), conforme protocolo do fabricante (BD Biosiences, NJ, EUA). Foram utilizados para a captura de antígenos $100 \mu \mathrm{L}$ de anticorpos monoclonais específicos para as citocinas: anti-IFN- $\gamma$, anti-IL-12, anti-IL-4, anti-IL-5, anti-IL-10, anti-TNF- $\alpha$ e anti-IL-17, em concentrações específicas $(1 \mathrm{ng} / \mathrm{ml})$ para cada citocina e incubadas durante a noite em câmara úmida refrigerada $\left(4{ }^{\circ} \mathrm{C}\right)$. Após a incubação, as placas foram lavadas com PBS/Tween $0,05 \%$ e bloqueadas por duas horas com $200 \mu$ de uma solução de BSA (do inglês, bovine serum albumine) a $1 \%$ e sacarose $5 \%$ em PBS. Após este período, as placas foram lavadas novamente, e $50 \mu \mathrm{l}$ de amostras ou da curva padrão de citocinas foram colocadas para incubação por mais duas horas a T.A. Após nova lavagem, foram adicionados $100 \mu \mathrm{l}$ de um segundo anticorpo policlonal biotinilado e incubados durante duas horas a T.A. As placas foram então novamente lavadas e incubadas com uma solução de Horseradish Peroxidase conjugada à avidina (Genzyme Diagnostics, Cambridge, MA) $1,25 \mathrm{ng} / \mathrm{ml}$ diluída em $1 \%$ BSA/PBS, durante vinte minutos a $37{ }^{\circ} \mathrm{C}$. Após três lavagens com PBS, foram adicionados $100 \mu \mathrm{l}$ de reagente tetrametilbenzidina 
(TMB; Sigma) para revelar a reação. Após cerca de trinta minutos a reação foi interrompida com ácido sulfúrico a 30\% e a absorbância foi lida num comprimento de onda de $450 \mathrm{~nm}$ no leitor de ELISA (SpectraMaxPlus Molecular devices).

\subsection{Análise estatística}

A análise estatística foi realizada utilizando o programa GraphPadPrism 5.0 (GraphPad Software, CA, EUA). Para análises dos dados clínicos, caracterização da população e estudos de associação com marcadores polimórficos, foram utilizadas tabelas de contingência do tipo 2x2, qui-quadrado, e teste de Fisher com correção de Yates, com intervalo de confiança de $95 \%$. Aos demais dados que não possuíam distribuição Gaussiana, a análise da comparação entre os grupos foi feita por testes não paramétricos de Mann-Whitney. As análises de correlação foram determinadas utilizando o teste não paramétrico de Spearman-s. O nível de significância adotado foi de $5 \%, 1 \%$ ou $0,1 \%$, ou seja, a probabilidade de $\mathrm{p}<0,05, \mathrm{p}<0,01$ ou $\mathrm{p}<0,001$ foram capazes de revelar a existência de diferenças estatisticamente significantes entre os dados dos diferentes grupos. 


\section{RESULTADOS}

\subsection{Dados clínicos}

O estudo incluiu 86 crianças que foram acompanhadas desde o nascimento até sessenta meses de idade. Aos trinta meses, após os testes clínicos, definimos 44 crianças como sibilantes (Sib) (25 meninos e 19 meninas), e 42 como não sibilantes (Não-Sib) (27 meninos e 15 meninas) (Tabela 3). A incidência das infecções respiratórias recorrentes foi maior entre as crianças sibilantes (84\%) quando comparada com as crianças não sibilantes (54\%), mostrando uma associação entre essas infecções e o quadro de sibilância (Fischer, **p=0,006; Tabela 3). O teste de hipersensibilidade mostrou que não houve diferença entre os grupos quanto ao grau de sensibilização. Ambos os grupos foram sensibilizados principalmente por Dermatophagoides pteronyssinus, Blatella germanica e Periplaneta americana (Fischer, p>0,05; Tabela 3). 
Tabela 3 - Dados clínicos de 86 crianças com alto risco de desenvolvimento de alergia, seguidas durante trinta meses.

\begin{tabular}{|c|c|c|c|c|}
\hline & Sibilantes & Não sibilantes & OR CI 95\% & p Value \\
\hline Individuos & 44 & 42 & & \\
\hline Raça & Miscigenados & Miscigenados & & \\
\hline \multicolumn{5}{|l|}{ Sexo } \\
\hline Meninos & 25 & 27 & 0.5739 a 3.261 & $\mathrm{p}=0.63$ \\
\hline Meninas & 19 & 15 & 0.3067 a 1.742 & $\mathrm{p}=0.62$ \\
\hline Infecções Respiratórias & 37 & 23 & 0.08332 a 0.6295 & $* * \mathrm{p}=0.06$ \\
\hline Eczema & 12 & 7 & 0.1656 a 1.351 & $\mathrm{p}=0,24$ \\
\hline Obstrução Nasal & 11 & 11 & 0.3564 a 2.476 & $\mathrm{p}=0,90$ \\
\hline Fumantes passivos & 12 & 12 & 0.3652 a 2.407 & $\mathrm{p}=0,91$ \\
\hline Animais dométicos & 13 & 13 & 0.3725 a 2.349 & $\mathrm{p}=0,92$ \\
\hline $\begin{array}{c}\text { Sensibilização } \\
\text { (pelo menos } 1 \text { antígeno) }\end{array}$ & 29 & 32 & 0.2067 a 1.431 & $\mathrm{p}=0,3167$ \\
\hline D. pteronyssinus & 21 & 24 & 0.6237 a 3.419 & $\mathrm{p}=0.51$ \\
\hline D. farinae & 13 & 9 & 0.2437 a 1.735 & $\mathrm{p}=0.53$ \\
\hline B. tropicalis & 7 & 7 & 0.3363 a 3.323 & $\mathrm{p}=0.84$ \\
\hline B. germanica & 15 & 12 & 0.3097 a 1.931 & $\mathrm{p}=0.74$ \\
\hline P. americana & 15 & 16 & 0.4928 a 2.872 & $\mathrm{p}=0.87$ \\
\hline Antígenos Cachorro & 6 & 4 & 0.1740 a 2.554 & $\mathrm{p}=0.79$ \\
\hline Antígenos de Gato & 5 & 3 & 0.1340 a 2.686 & $\mathrm{p}=0.76$ \\
\hline Fungos (mix) & 8 & 10 & 0.4947 a 3.998 & $\mathrm{p}=0.70$ \\
\hline Polén (mix) & 4 & 5 & 0.3369 a 5.420 & $\mathrm{p}=0.94$ \\
\hline Antígenos de Ratos & 11 & 13 & 0.5224 a 3.462 & $\mathrm{p}=0.70$ \\
\hline Antígenos de Camundongos & 12 & 9 & 0.2697 a 1.961 & $\mathrm{p}=0.70$ \\
\hline Leite de Vaca & 3 & 4 & 0.3020 a 6.853 & $\mathrm{p}=0.94$ \\
\hline Ovo & 3 & 4 & 0.3020 a 6.853 & $\mathrm{p}=0.94$ \\
\hline Soja & 1 & 5 & 0.6490 a 52.03 & $\mathrm{p}=0.18$ \\
\hline
\end{tabular}


4.2 Exposição precoce à endotoxina ambiental entre crianças sibilantes e não sibilantes

Nos primeiros seis meses de vida foi coletada a poeira domiciliar presente nos pisos das casas das crianças, e realizada a dosagem de endotoxina. A média total da concentração de endotoxina encontrada nas amostras de poeira foi de 33,89 EU/mg. As crianças foram classificadas em dois grupos: um grupo exposto a níveis de endotoxina inferior a $50 \mathrm{EU} / \mathrm{mg}$ (64 crianças, com média de 17,38EU/mg) e outro grupo exposto a níveis de endotoxina acima de 50EU/mg (20 crianças, com média de 86,72EU/mg). Dentro destes grupos, as crianças foram ainda sub-classificadas como sibilantes e não sibilantes. Os resultados mostram que a exposição à endotoxina no início da vida não tem relação com o desenvolvimento de sibilância (Mann-Whitney, p >0,05; Figura 2). 


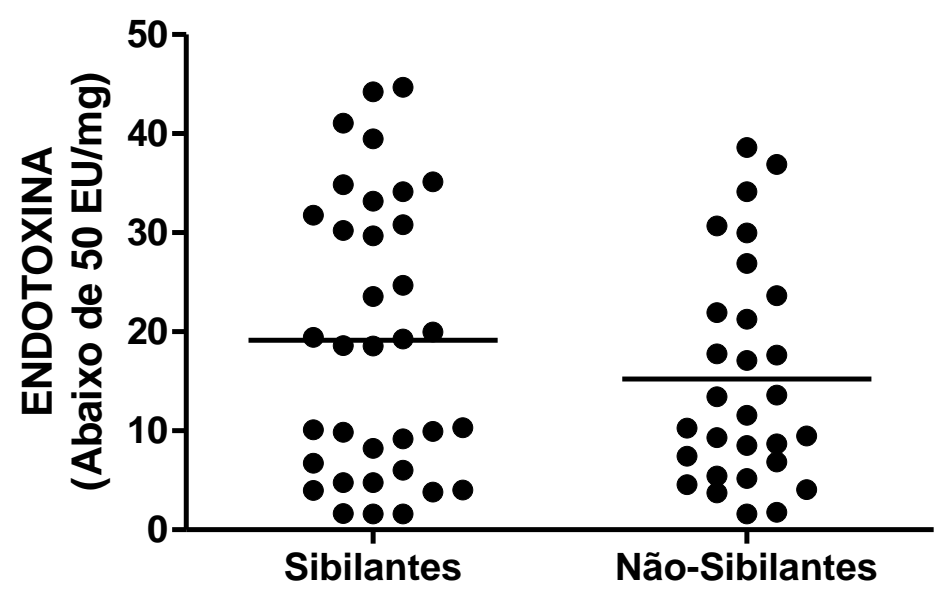

B)

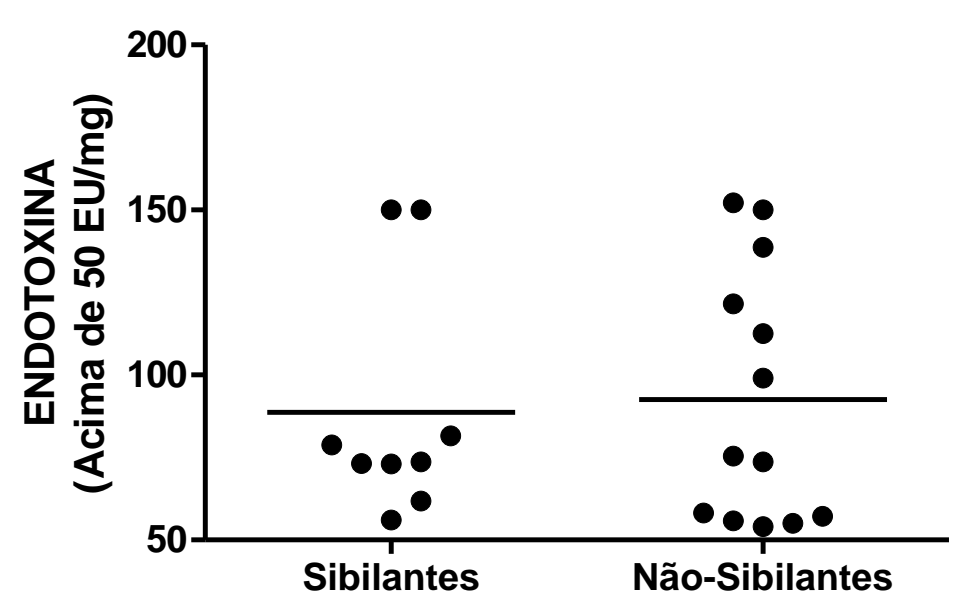

Figura 2. Distribuição de crianças sibilantes e não sibilantes de acordo com a exposição precoce à endotoxina ambiental. Crianças Sib e Não Sib seguiram uma distribuição similar de acordo com os níveis de exposição à endotoxina (A) abaixo 50EU/mg (Não-Sib n=29 e Sib n=35; Mann-Whitney, p>0,05) ou (B) acima de 50EU/mg (Não-Sib n=13; Sib n=9; Mann-Whitney, p>0.05). 


\subsection{Exposição precoce à endotoxina ambiental e a produção de IL-12p70 e}

IFN- $\gamma$ por PBMC de crianças sibilantes e não sibilantes, estimuladas com LPS

Aos trinta meses de idade foi colhido o sangue das crianças e as PBMC foram cultivadas com e sem LPS e o sobrenadante foi coletado em duas, 12, 24 e 48 horas, para análise de liberação de citocinas entre os grupos de sibilantes e não sibilantes, de classificados de acordo com a exposição precoce à endotoxina ambiental. Observamos que PBMC de crianças sibilantes expostas à endoxina acima de 50 EU/mg produziram quantidades menores de IL-12p70 e IFN- $\gamma$ comparado com o grupo de crianças não sibilantes (Mann-Whitney, ${ }^{*} \mathrm{p}<0,05$; Figuras 3A,B e 4A,B). Para confirmar este resultado realizamos uma correlação entre a produção de IL-12p70 e IFN- $\gamma$ por PBMC estimuladas com LPS e o grau de exposição à endotoxina ambiental e notamos que no grupo de crianças não sibilantes existe uma correlação positiva (Spearman, $r=0,57$, ${ }^{*} \mathrm{p}<0,01$; Figura 3D; Spearman, $r=0,61,{ }^{* *} \mathrm{p}=0,003$; Figura 4D), o que não foi verificado no grupo de crianças sibilantes (Spearman, r=0,29, p=0,54; Figura 3C; Spearman $r=0,13, p>0,05$; Figura 4C). 
A)

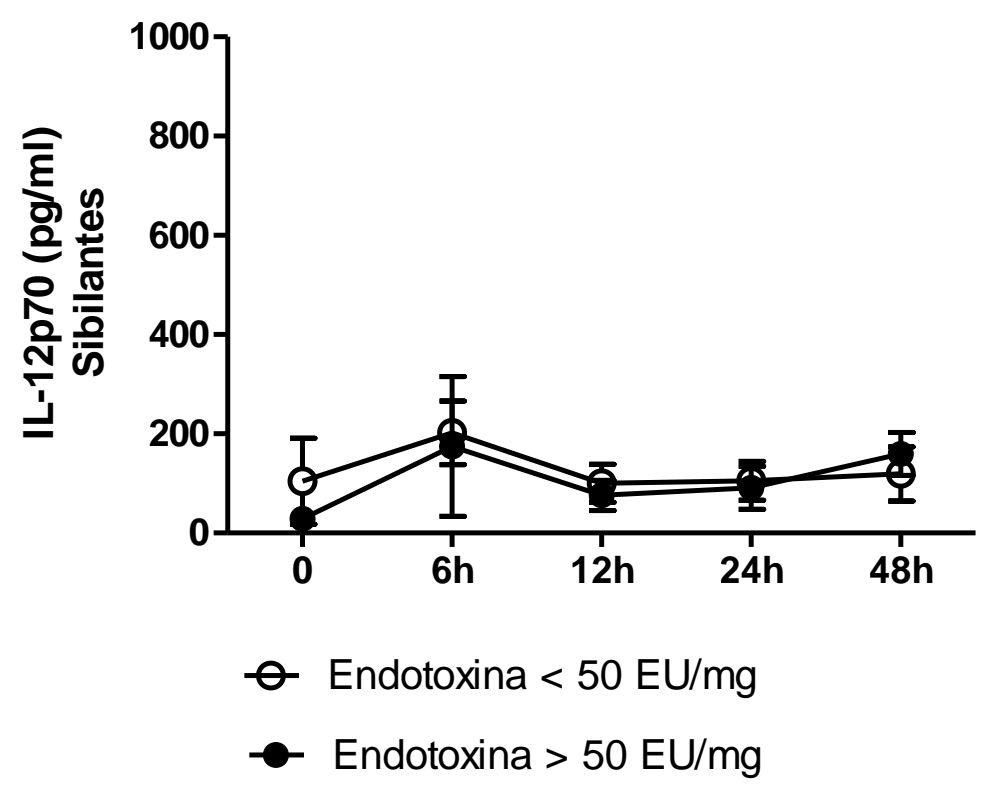

B)

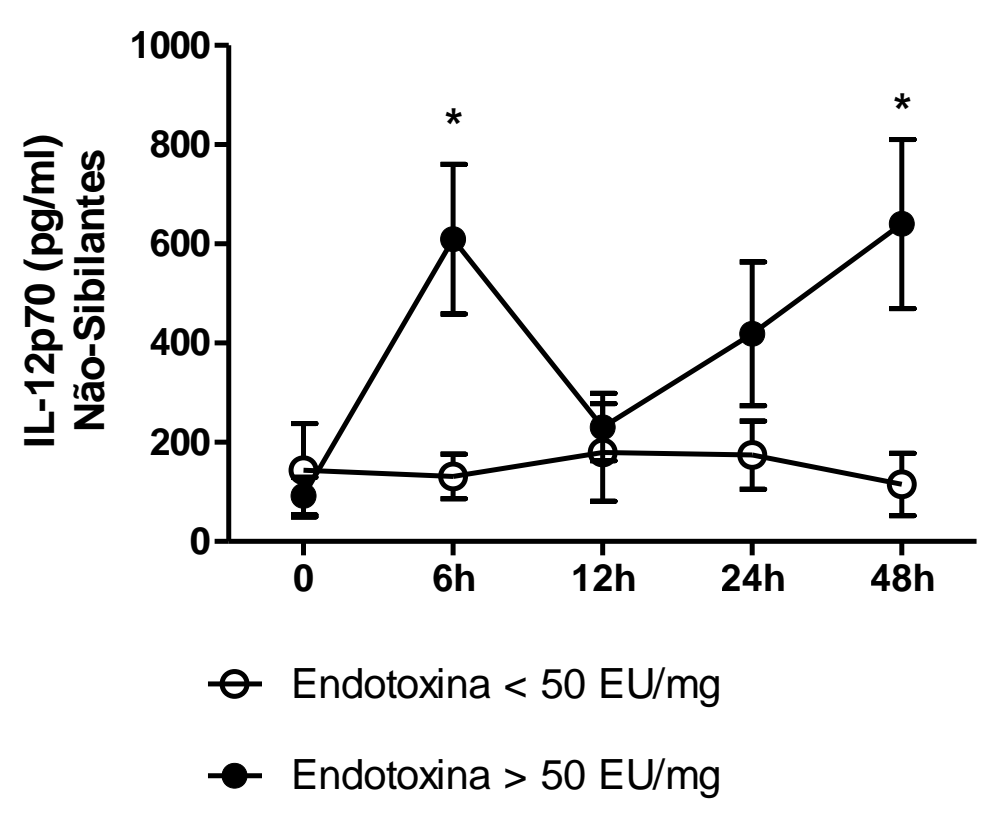


C)

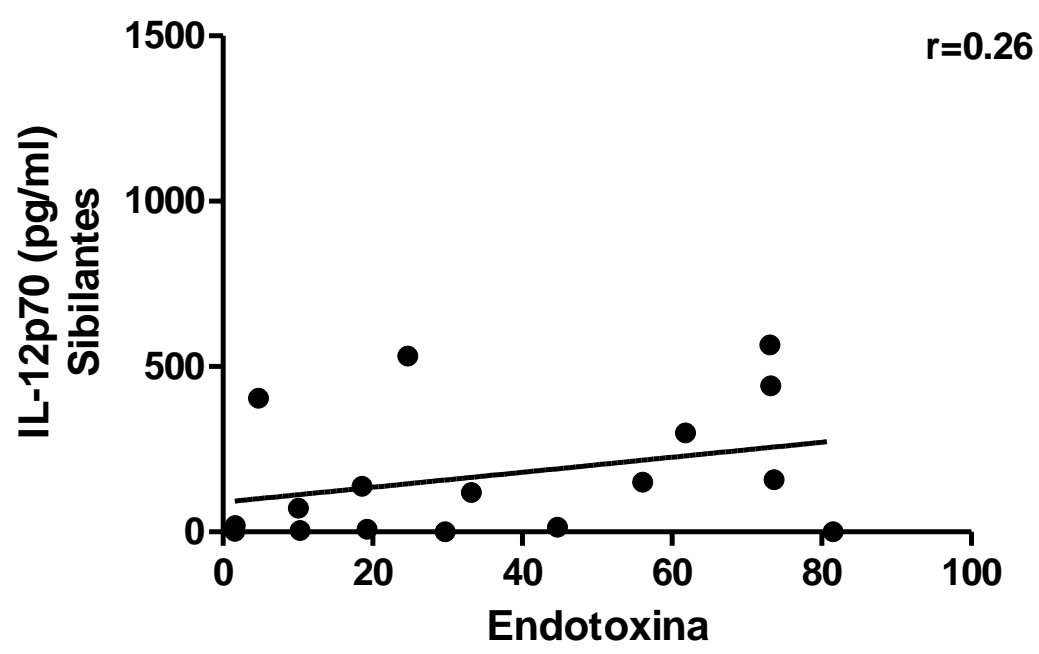

D)

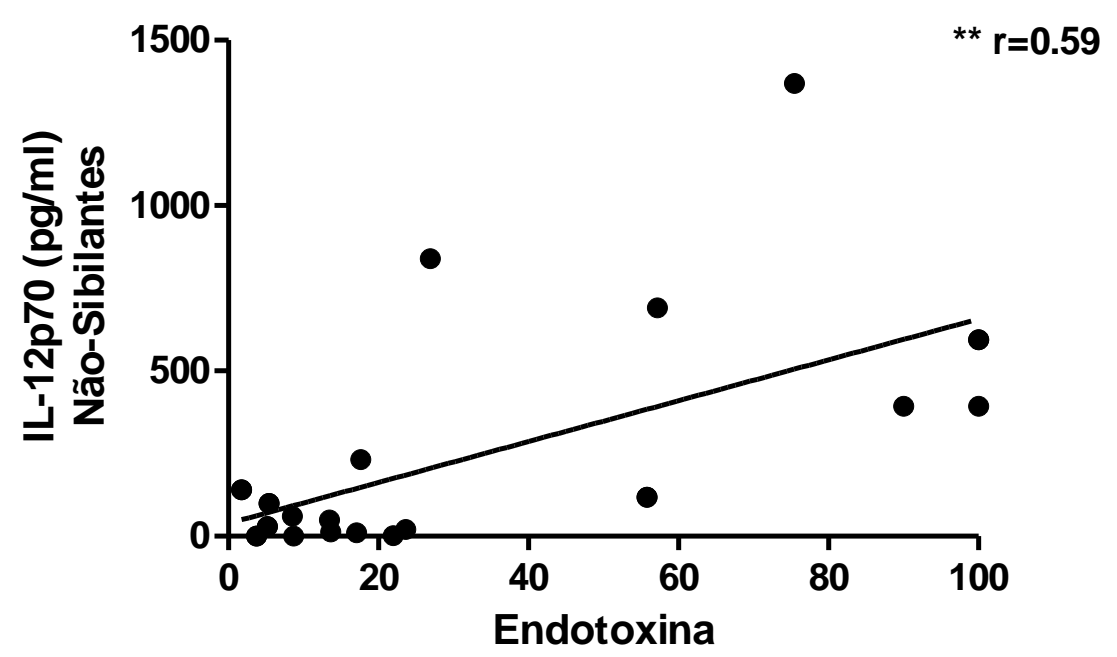

Figura 3. Produção de IL-12 por PBMC de crianças sibilantes e não sibilantes. (A) PBMC estimuladas com LPS de crianças Sib expostas a níveis de endotoxina abaixo ou acima de 50EU/mg produziram quantidades equivalentes de IL-12p70 (Mann Whitney, p>0,05). (B) PBMC estimuladas com LPS de crianças Não-Sib expostas a níveis de endotoxina acima de 50EU/mg produziram quantidades maiores de IL-12p70 comparadas com PBMC de crianças expostas a níveis de endotoxina acima de $50 E U / m g$ e de crianças Sib (Mann Whitney, ${ }^{*} p<0,05$ ). (C) Não existe uma correlação significativa entre a os níveis de exposição à endotoxina e a produção de IL-12p70 por PBMC de crianças Sib (Spearman, $r=0,29, p=0,54$ ). (D) Existe uma correlação significativa entre os níveis de exposição à endotoxina e a produção de IL-12p70 por PBMC de crianças Não-Sib (Spearman, $r=0,57,{ }^{*} p<0,01$ ). 
A)

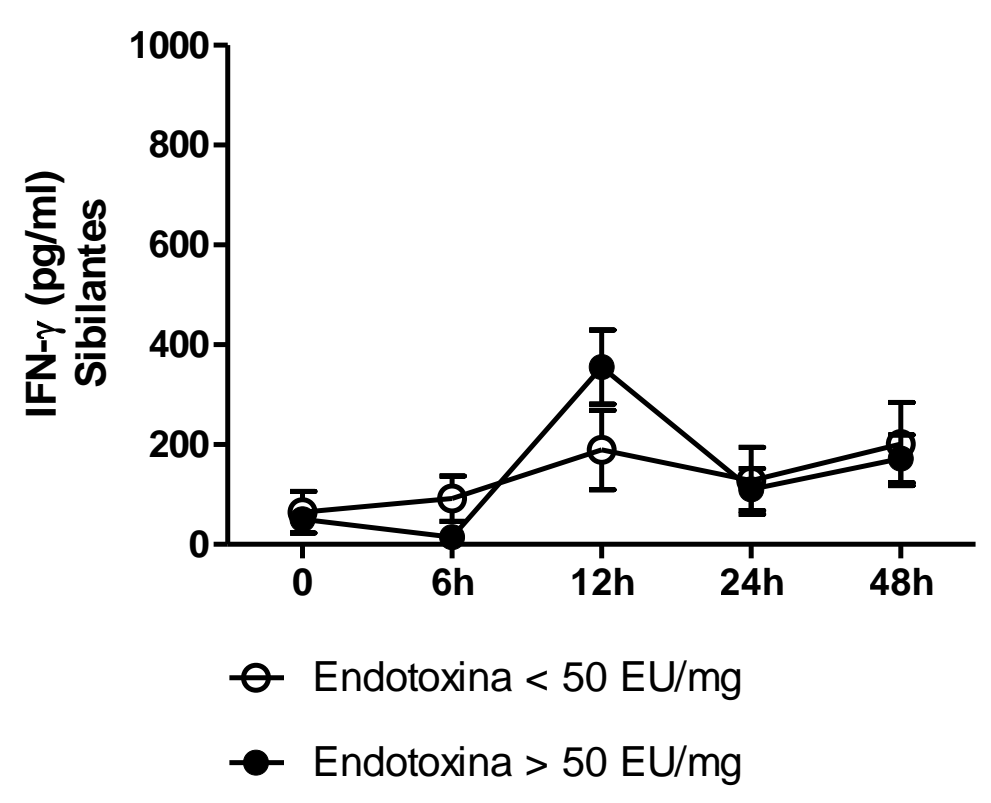

B)

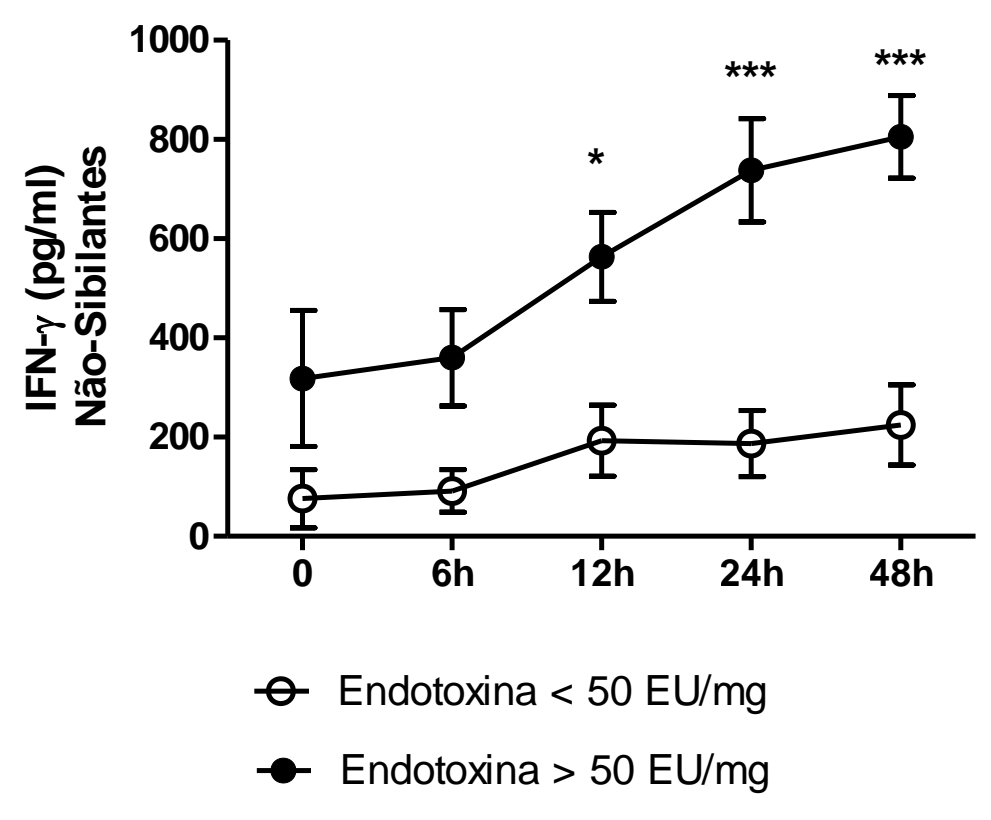


C)

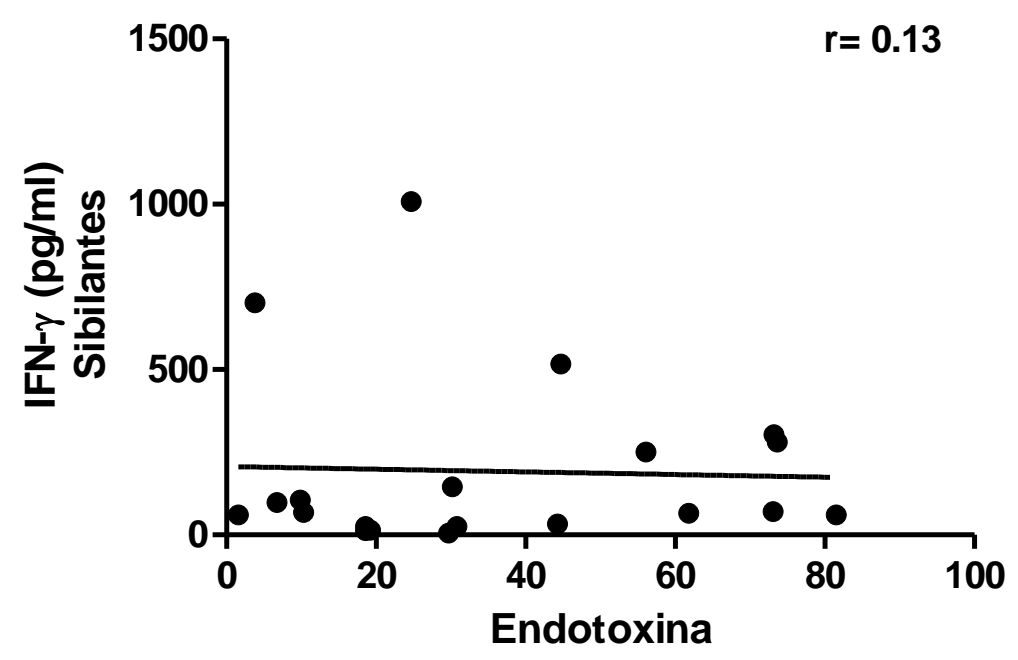

D)

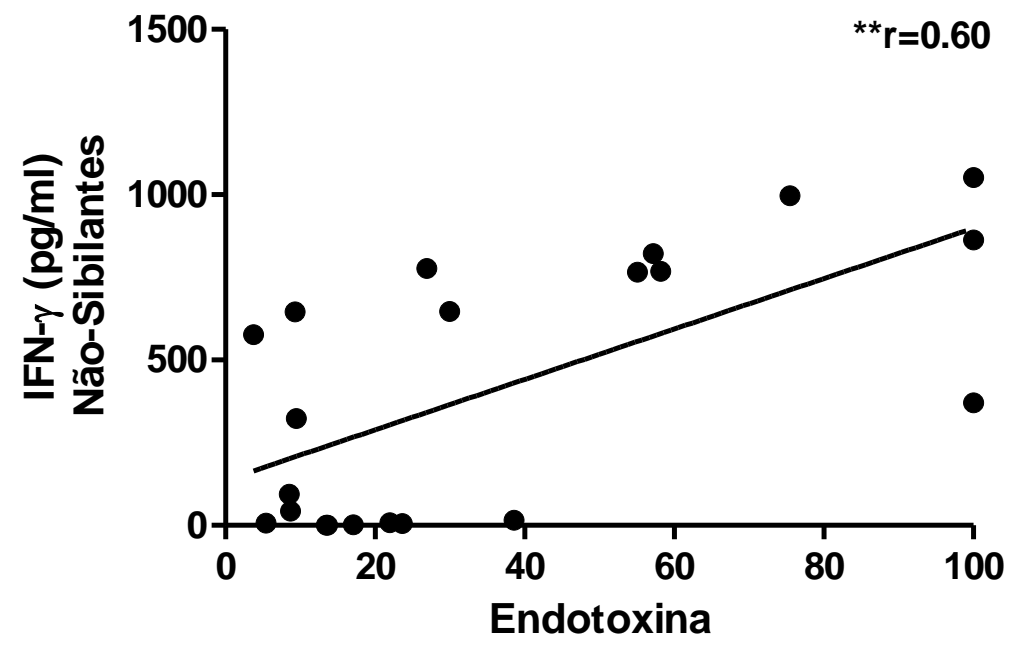

Figura 4. Produção de IFN- $\gamma$ por PBMC de crianças sibilantes e não sibilantes. (A) PBMC estimuladas com LPS de crianças Sib expostas a níveis de endotoxina abaixo ou acima de 50EU/mg produziram quantidades equivalentes de IFN- $\gamma$ (Mann Whitney, p>0,05) (B) PBMC estimuladas com LPS de crianças Não-Sib expostas a níveis de endotoxina acima de 50EU/mg produziram quantidades maiores de IFN- $\gamma$ comparadas com PBMC de crianças expostas a níveis de endotoxina acima de $50 \mathrm{EU} / \mathrm{mg}$ e de crianças Sib (Mann-Whitney, ${ }^{*} \mathrm{p}<0,05$; ***p=0,0001). (C) Não existe uma correlação significativa entre a os níveis de exposição à endotoxina e a produção de IFN- $\gamma$ por PBMC de crianças Sib (Spearman, $r=0.13, p>0,05$ ). (D) Existe uma correlação significativa entre os níveis de exposição à endotoxina e a produção de IFN- $\gamma$ por PBMC de crianças Não-Sib (Spearman, $r=0,61$, ** $p<0,003$ ). 
4.4 Exposição precoce à endotoxina ambiental e a produção de TNF- $\alpha$, IL10, IL-4, IL-5 e IL-17 por PBMC de crianças sibilantes e não sibilantes, estimuladas com LPS

A produção de TNF- $\alpha$, IL-10, IL-4, IL-5 e IL-17 por PBMC estimulada com LPS de crianças sibilantes e não sibilantes foi semelhante nos dois grupos de exposição à endotoxina ambiental, abaixo e acima de 50EU/mg (Mann-Whitney, p>0,05; Figuras 5 a 8). 


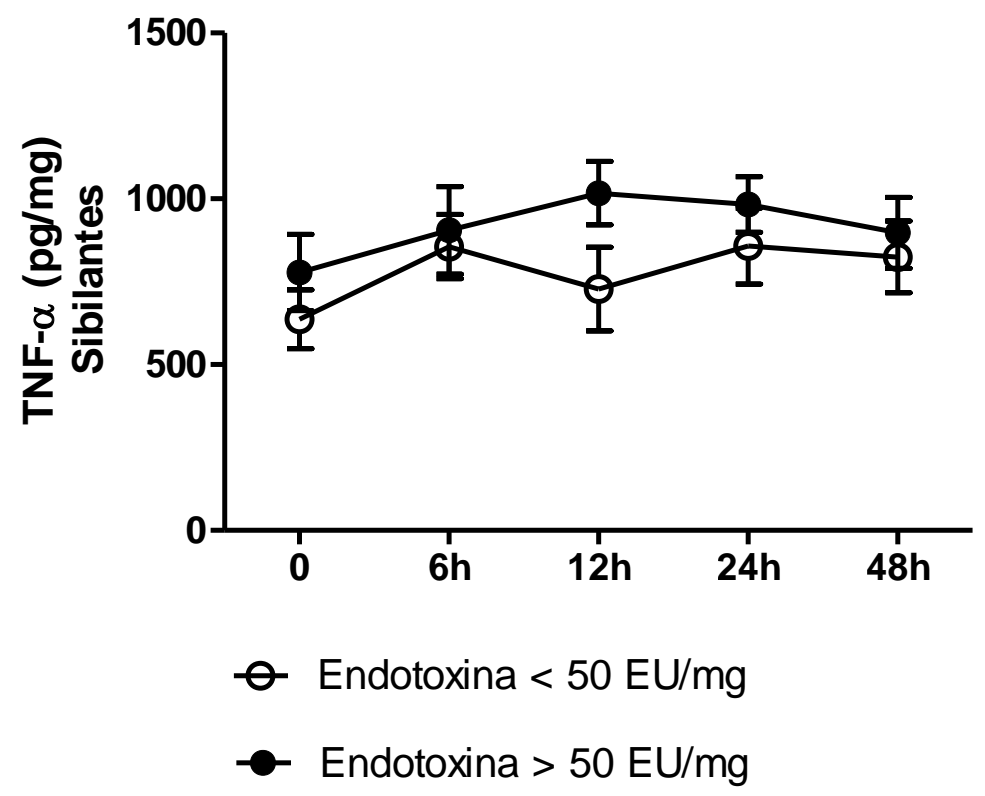

B)

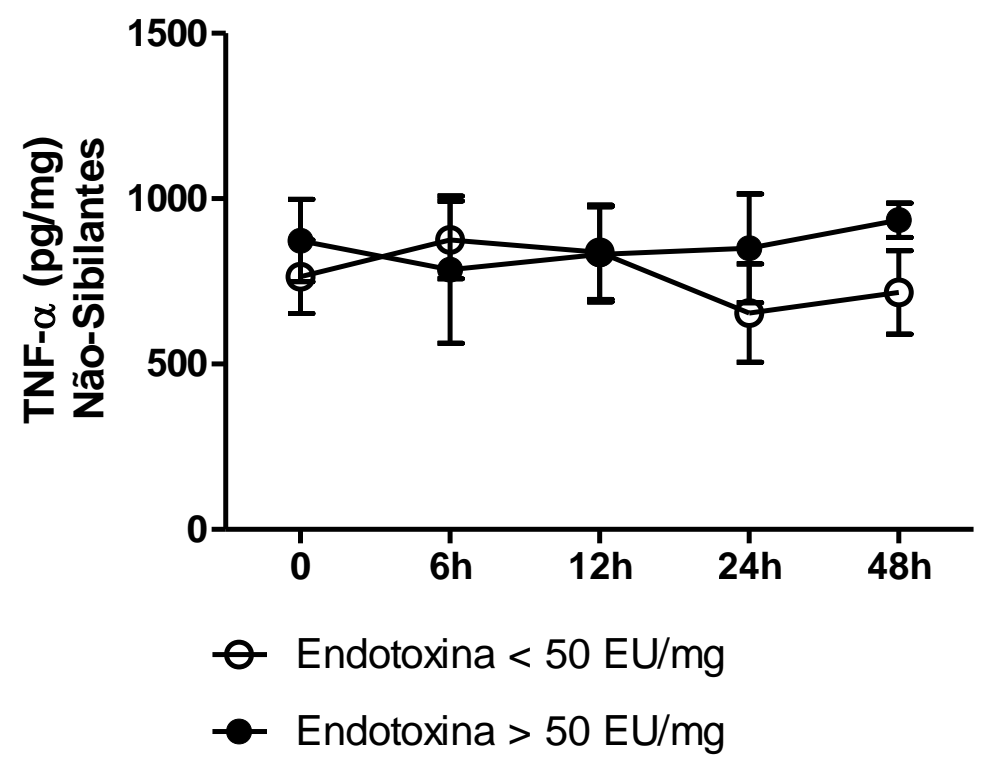

Figura 5. Produção de TNF- $\alpha$ por PBMC de crianças sibilantes e não sibilantes. PBMC estimuladas com LPS de crianças Sib e Não-Sib produziram quantidades similares de TNF- $\alpha$ independente da exposição ambiental à endotoxina, abaixo e acima de 50EU/mg. (A) Sib (Mann Whitney, p>0,05) e (B) Não-Sib (Mann Whitney, p>0,05). 


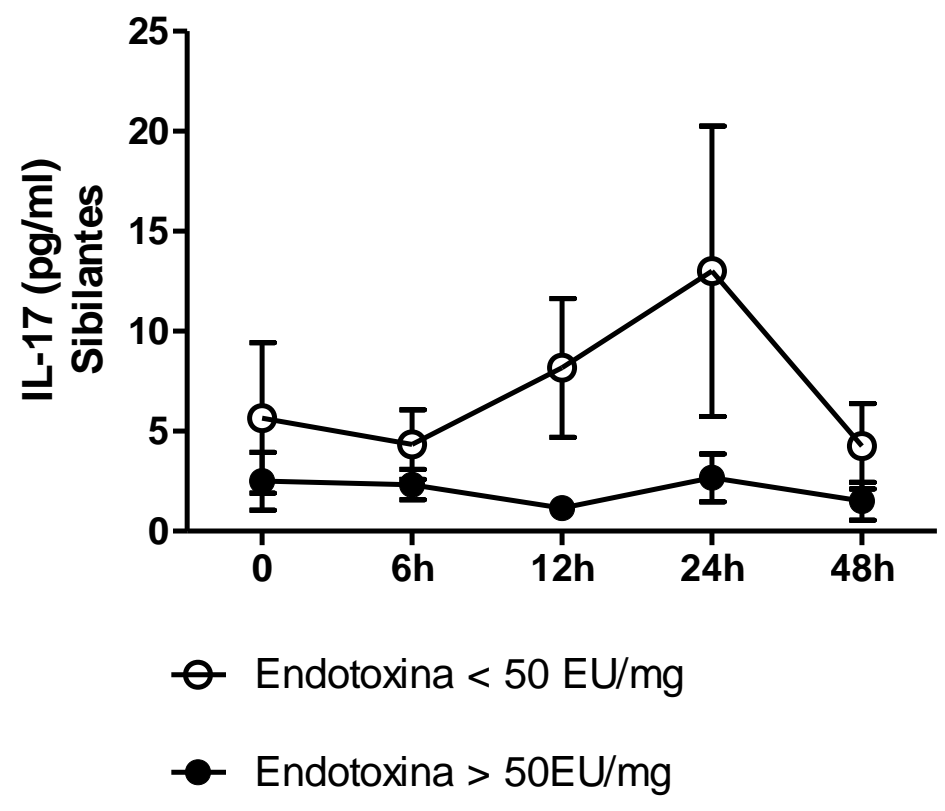

B)

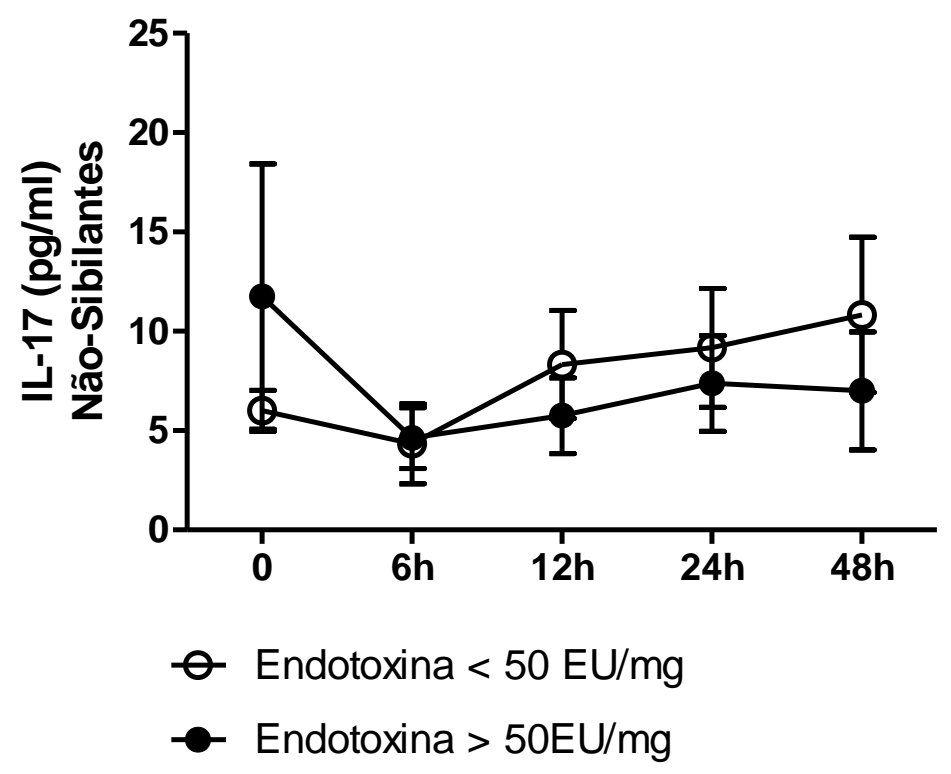

Figura 6. Produção de IL-17 por PBMC de crianças sibilantes e não sibilantes. PBMC estimuladas com LPS de crianças Sib e Não-Sib produziram quantidades similares de IL-17 independente da exposição ambiental à endotoxina, abaixo e acima de 50EU/mg. (A) Sib (Mann Whitney, p>0,05) e (B) Não-Sib (Mann Whitney, p>0,05). 


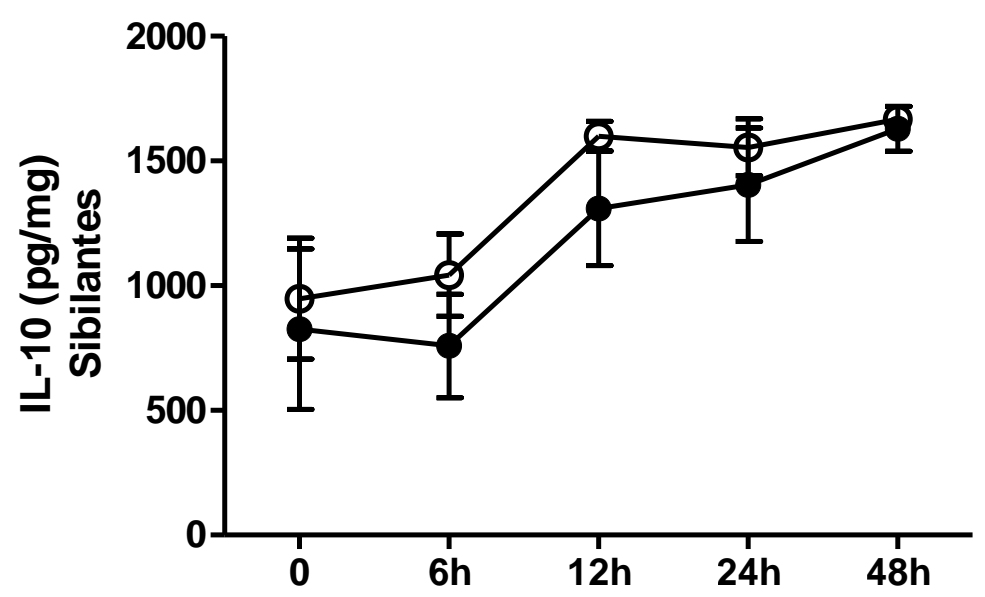

Endotoxina $<50 \mathrm{EU} / \mathrm{mg}$

- Endotoxina > $50 \mathrm{EU} / \mathrm{mg}$

B)

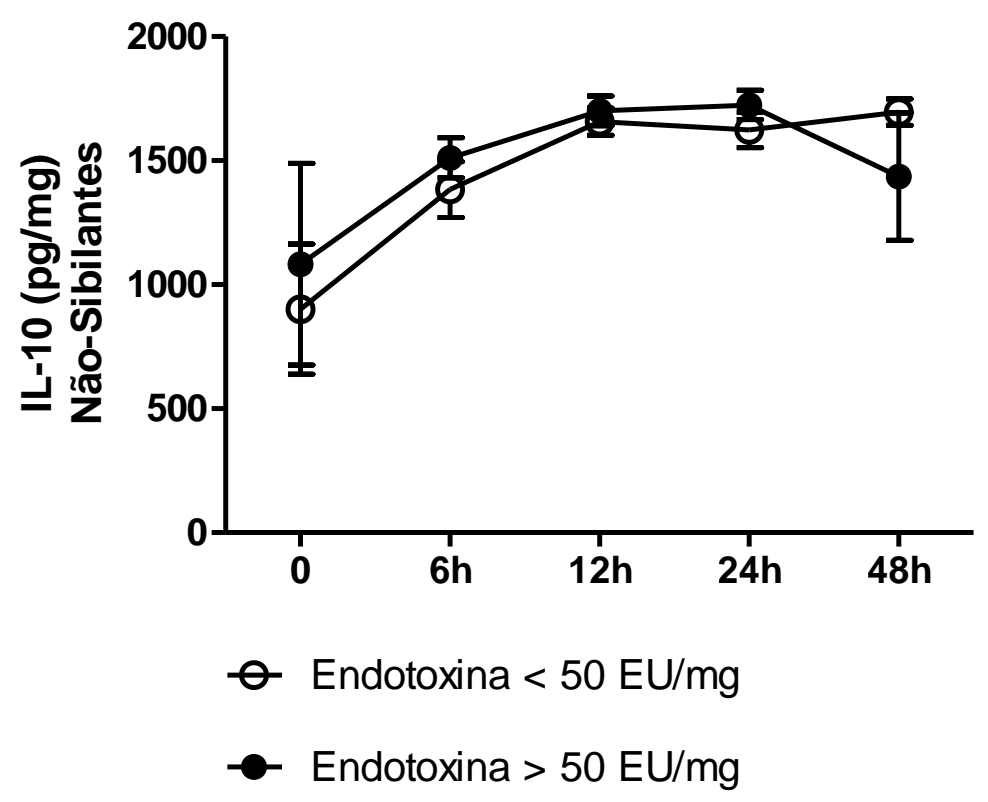

Figura 7. Produção de IL-10 por PBMC de crianças sibilantes e não sibilantes. PBMC estimuladas com LPS de crianças Sib e Não-Sib produziram quantidades similares de IL-10 independente da exposição ambiental à endotoxina, abaixo e acima de 50EU/mg. (A) Sib (Mann Whitney, p>0,05) e (B) Não-Sib (Mann Whitney, p>0,05). 


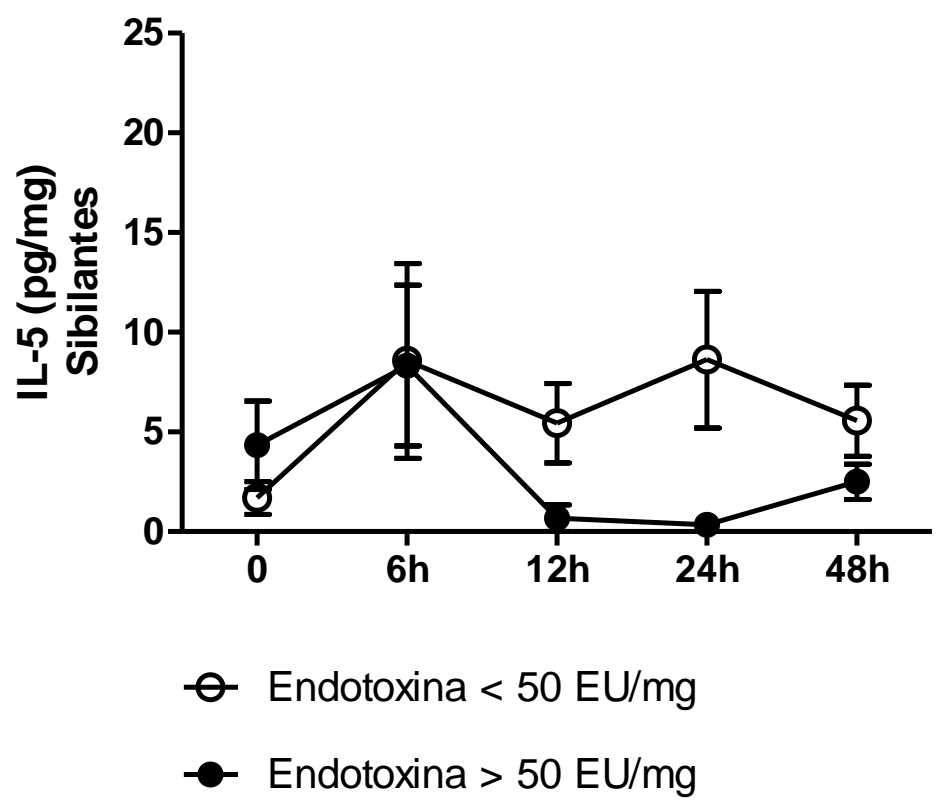

B)

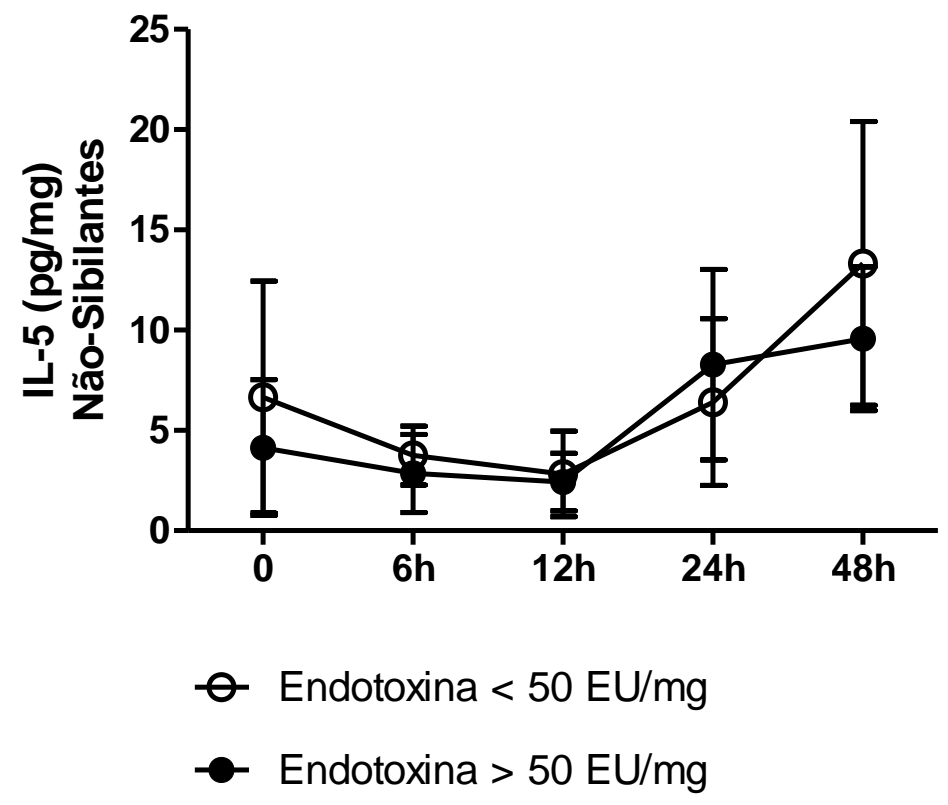

Figura 8. Produção de IL-5 por PBMC de crianças sibilantes e não sibilantes. PBMC estimuladas com LPS de crianças Sib e Não-Sib produziram quantidades similares de IL-5 independente da exposição ambiental à endotoxina, abaixo e acima de 50EU/mg. (A) Sib (Mann Whitney, p>0,05) e (B) Não-Sib (Mann Whitney, p>0,05). 


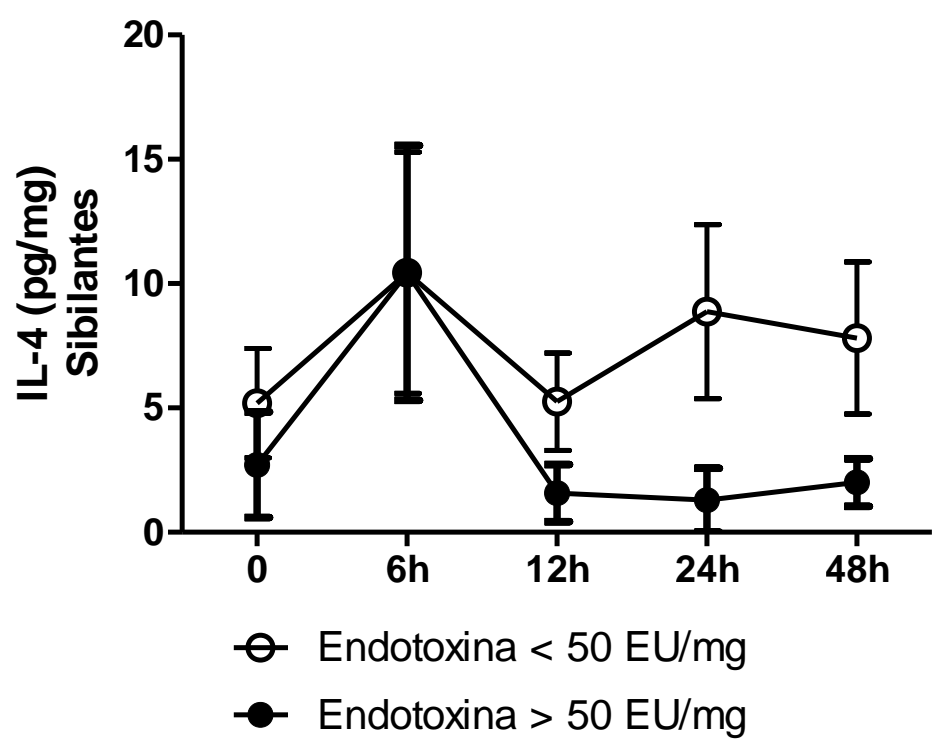

B)

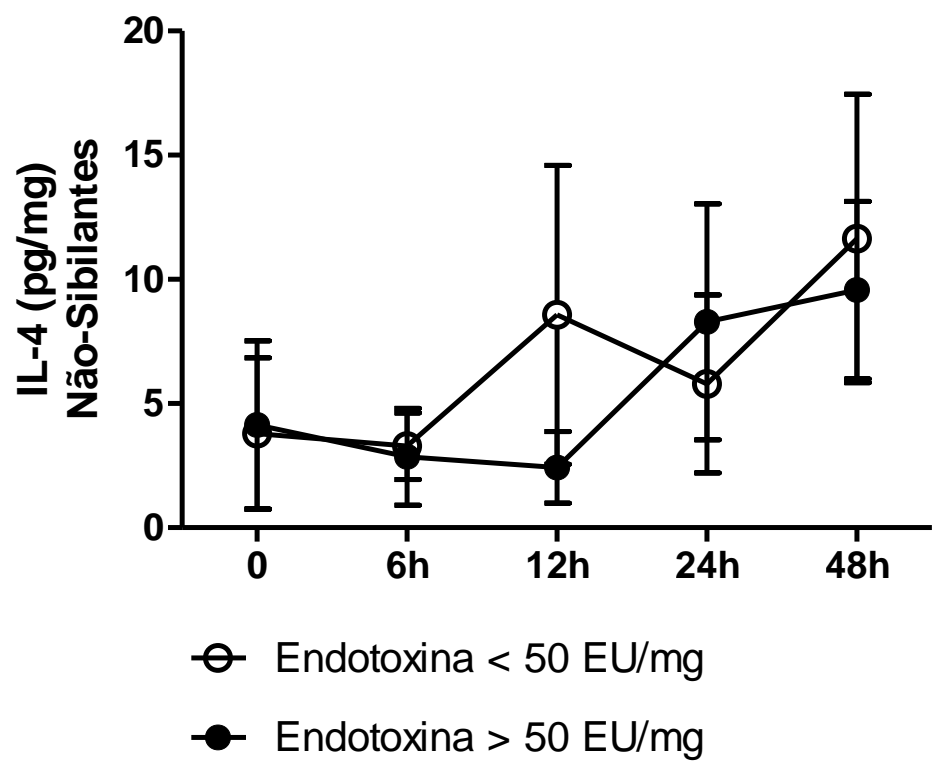

Figura 9. Produção de IL-4 por PBMC de crianças sibilantes e não sibilantes. PBMC estimuladas com LPS de crianças Sib e Não-Sib produziram quantidades similares de IL-4 independente da exposição ambiental à endotoxina, abaixo e acima de 50EU/mg. (A) Sib (Mann Whitney, p>0,05) e (B) Não-Sib (Mann Whitney, p>0,05). 


\subsection{Prevalência de polimorfismos nos genes de TLR4 e CD14, receptores}

envolvidos no reconhecimento de LPS

O polimorfismo Asp299Gly no gene de TLR 4 é detectado por meio de digestão do produto de amplificação com a enzima Nco I. O alelo mais frequente na população apresenta uma banda de 249pb, denominado alelo 299D. Quando o produto de amplificação é digerido, o alelo 299G é revelado. Indivíduos com uma banda de 249pb são definidos como homozigotos com genótipo D299D. Quando são visualizadas três bandas (249pb, 172pb e $77 \mathrm{pb}$ ), apenas um alelo foi clivado, revelando indivíduo heterozigoto com genótipo D299G. Indivíduos com duas bandas de 172pb e 77pb são considerados homozigotos com genótipo G299G (Figura 10).

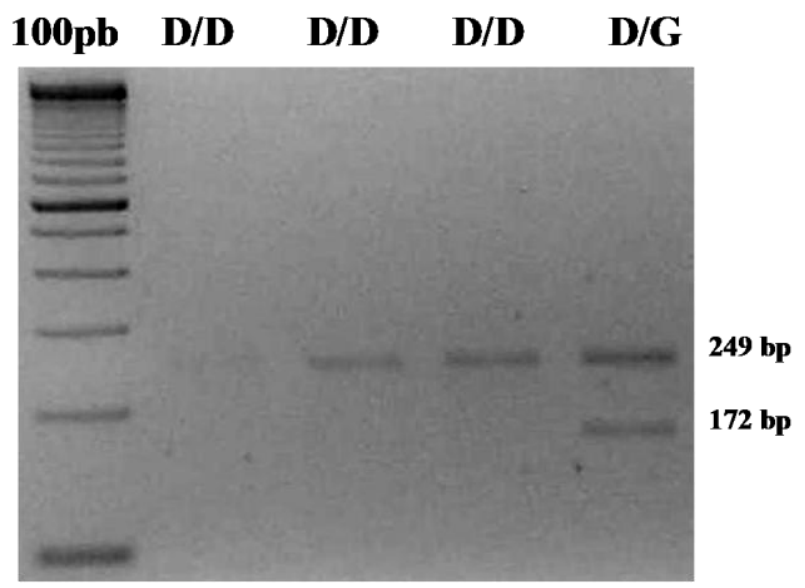

Figura 10. Polimorfismo no gene TLR4 (Asp299Gly): Produtos da amplificação do gene do TLR4 digeridos com enzima Nco I. A figura ilustra três homozigotos com genótipo D299D, e um heterozigoto com genótipo D299G, apresentando duas bandas, de $249 \mathrm{pb}$ e $172 \mathrm{pb}$ (a banda de $77 \mathrm{pb}$ não é mostrada, por estar "fora do gel"). Os fragmentos foram observados em gel de agarose $4 \%$ corados com brometo de etídeo. Para este experimento foi utilizado o marcador de 100pb de DNA (Invitrogen).

Portanto, foi possível avaliar a frequência dos genótipos e alelos em 41 crianças, sendo 19 Sibilantes e 22 Não sibilantes. Observamos que $95 \%$ das crianças sibilantes e 100\% das crianças não sibilantes apresentaram o genótipo D299D. Apenas $3 \%$ das crianças sibilantes e nenhuma das crianças Não sibilantes apresentaram o alelo polimórfico 299G. A porcentagem entre os genótipos e alelos entre os grupos não variou de maneira significativa (Fischer, p>0,05; Tabela 4). 
Tabela 4 - Frequência dos genótipos e alelos TLR4 (Asp299Gly) na coorte.

\begin{tabular}{ccc}
\hline & Não Sibilantes & Sibilantes \\
\hline Genótipos & n/porcentagem & n/porcentagem \\
\hline G299G & $0(0,00)$ & $0(0,00)$ \\
D299G & $0(0,00)$ & $1(0,05)$ \\
D299D & $22(1,00)$ & $18(0,95)$ \\
Total & 22 & 19 \\
$\underline{\text { Alelos }}$ & & \\
D & $44(1,00)$ & $37(0,97)$ \\
G & $0(0,00)$ & $1(0,03)$ \\
Total & 44 & 38 \\
\hline
\end{tabular}

O polimorfismo $C$ - $159 T$ no promotor do gene que codifica CD14 é detectado por meio de digestão do produto de amplificação com a enzima AVAII. O alelo mais frequente na população apresenta uma banda de 497 pb e é denominado de alelo -159C. Quando o produto de amplificação é digerido, o alelo -159T é revelado. Indivíduos com uma banda de 497pb são definidos como homozigotos com genótipo C-159C. Quando são visualizadas três bandas (497pb, 353pb e 144pb), apenas um alelo foi clivado, revelando indivíduo heterozigoto com genótipo C-159T. Indivíduos com duas bandas de $353 \mathrm{pb}$ e 144pb são definidos como homozigotos com genótipo T-159T (Figura 11). 


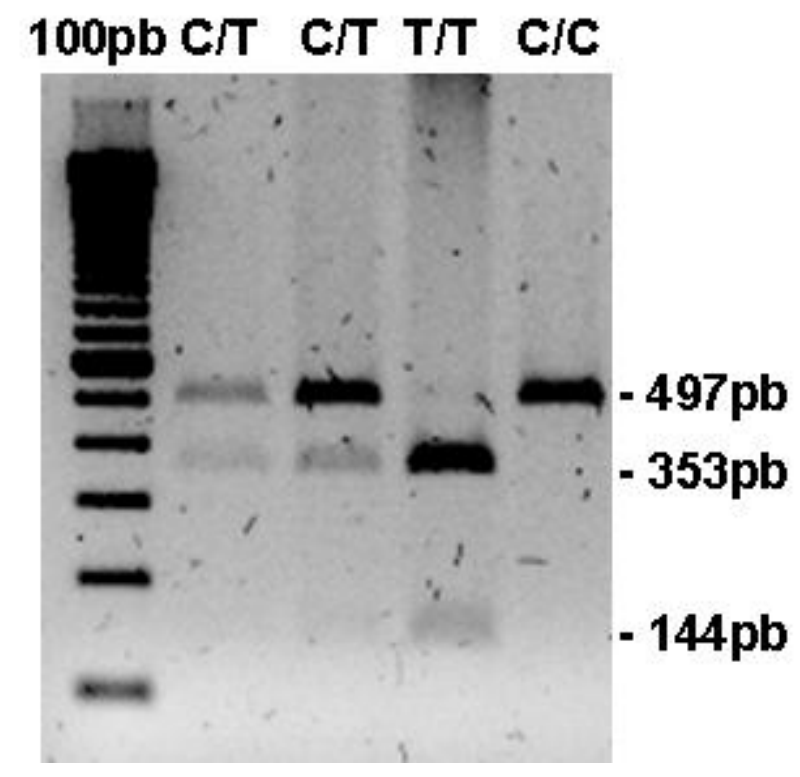

Figura 11 Polimorfismo no gene CD14 (C-159T): Produtos de amplificação digeridos com Ava II ilustrando quatro indivíduos, sendo dois heterozigotos para o polimorfismo C159T, apresentando três bandas $(497 \mathrm{pb}, 353 \mathrm{pb}$ e $144 \mathrm{pb})$, um homozigoto com genótipo T-159T, apresentando duas bandas (353pb e $144 \mathrm{pb})$ e um homozigoto com genótipo C-159C, apresentando uma banda de 497pb. Os fragmentos foram observados em gel de agarose 4\% marcado com brometo de etídeo. Para este experimento foi utilizado o marcador de 100pb DNA.

Foi possível avaliar 53 crianças, sendo 27 sibilantes e 26 não sibilantes. Observamos que 38,46\% das crianças sibilantes apresentaram o genótipo T-159T, 46,15\% o genótipo C-159T e 15,38\% o genótipo C-159C. Além de que 25,92\% das crianças não sibilantes apresentaram o genótipo T-159T, 59,25\% o genótipo C-159C e 14,81\% o genótipo C-159C. No grupo de crianças sibilantes, $61,53 \%$ apresentaram o alelo $159 \mathrm{C}$ e $38,46 \%$ o alelo $159 \mathrm{~T}$. Dentre os Não sibilantes, 55,55\% apresentaram o alelo $159 \mathrm{C}$ e $44 \%$ o alelo $159 \mathrm{~T}$. A porcentagem entre os genótipos e alelos entre os grupos não variou de maneira significativa (Fischer, $p>0,05$; Tabela 5). 
Tabela 5 - Frequência dos genótipos e alelos CD14 na população estudada.

\begin{tabular}{ccc}
\hline & Não sibilantes & Sibilantes \\
\hline Genótipos & n/porcentagem & n/porcentagem \\
\hline T-159T & $7(25,92)$ & $10(38,46)$ \\
C-159T & $16(59,25)$ & $12(46,15)$ \\
C-159C & $4(14,81)$ & $4(15,38)$ \\
Total & 27 & 26 \\
Alelos & & \\
\hline $\mathbf{C}$ & $30(55,55)$ & $32(61,53)$ \\
$\mathbf{T}$ & $24(44,44)$ & $20(38,46)$ \\
Total & 54 & 52 \\
\hline
\end{tabular}

Além da sua relação com o desenvolvimento de sibilância, avaliamos se o polimorfismo de CD14 está associado com a sensibilização aos alérgenos e com a produção de citocinas por PBMC, estimuladas ou não com LPS de crianças sibilantes e não sibilantes. Podemos observar que o polimorfismo no gene de CD14 está associado com a sensibilização ao alérgeno Periplaneta americana (alérgeno de barata) (Fischer, ${ }^{*} \mathrm{p}<0,05$; Tabela 6) e a alérgenos de fungos (Fischer, ${ }^{*} \mathrm{p}<0,05$; Tabela 7).

Quanto à produção de citocinas, podemos observar que crianças não sibilantes com genótipo polimórfico C-159C produziram altas quantidades de IFN- $\gamma$ e IL-10 sem estímulo com LPS quando comparado com crianças não sibilantes que apresentaram o genótipo não polimórfico T-159T. Em crianças Sibilantes não houve diferença na produção de citocinas (Mann-Whitney, ${ }^{*} \mathrm{p}<0,05$; Figuras 12 e 13). 
Tabela 6 - Polimorfismo C-159T no gene de CD14 associado com sensibilização ao $P$. americana.

\begin{tabular}{ccc}
\hline Per a1 & Não sensível & Sensível \\
\hline Genótipos & n/porcentagem & n/porcentagem \\
T-159T & $11(55)$ & $6(21)$ \\
C-159T & $6(3)$ & $18(64)$ \\
C-159C & $3(15)$ & $4(14)$ \\
Total & 20 & 28 \\
*Fischer, ${ }^{*} \mathrm{p}<0,05$ & &
\end{tabular}

Tabela 7 - Polimorfismo C-159T no gene de CD14 associado com sensibilização a alérgenos de fungos.

\begin{tabular}{ccc}
\hline Fungos & Não sensível & Sensível \\
\hline Genótipos & n/porcentagem & n/porcentagem \\
\hline T-159T & $16(40)$ & $1(8)$ \\
C-159T & $22(55)$ & $6(50)$ \\
C-159C & $2(5)$ & $5(41)$ \\
Total & 40 & 12 \\
\hline
\end{tabular}

*Fischer, ${ }^{*} \mathrm{p}<0,05$

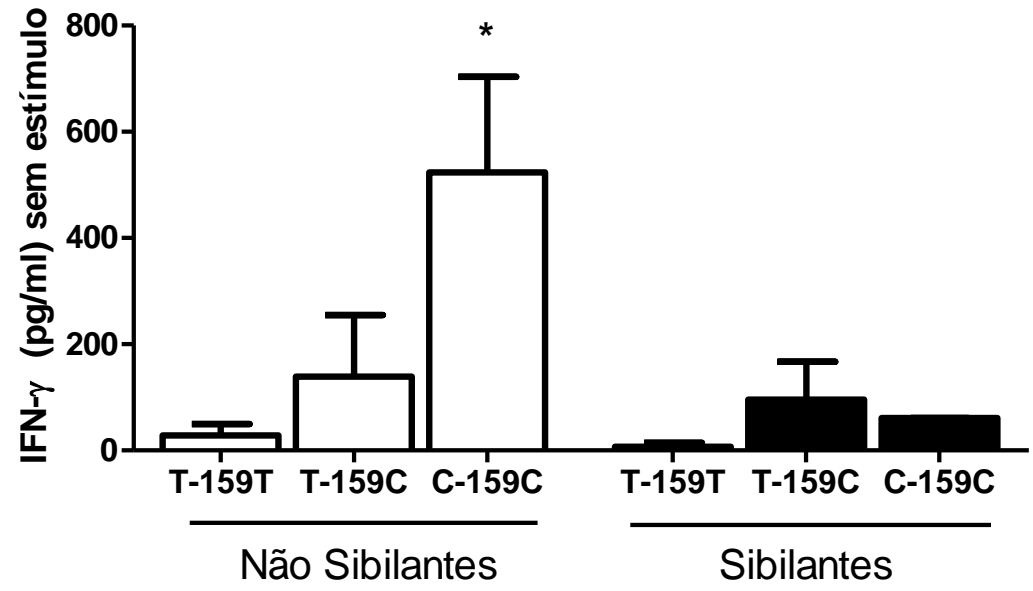

Figura 12. Polimorfismo C159C de CD14 associado com maior produção de IFN- $\gamma$ basal. Dosagem de citocinas por ELISA. Mann-Whitney, *p<0,05. 


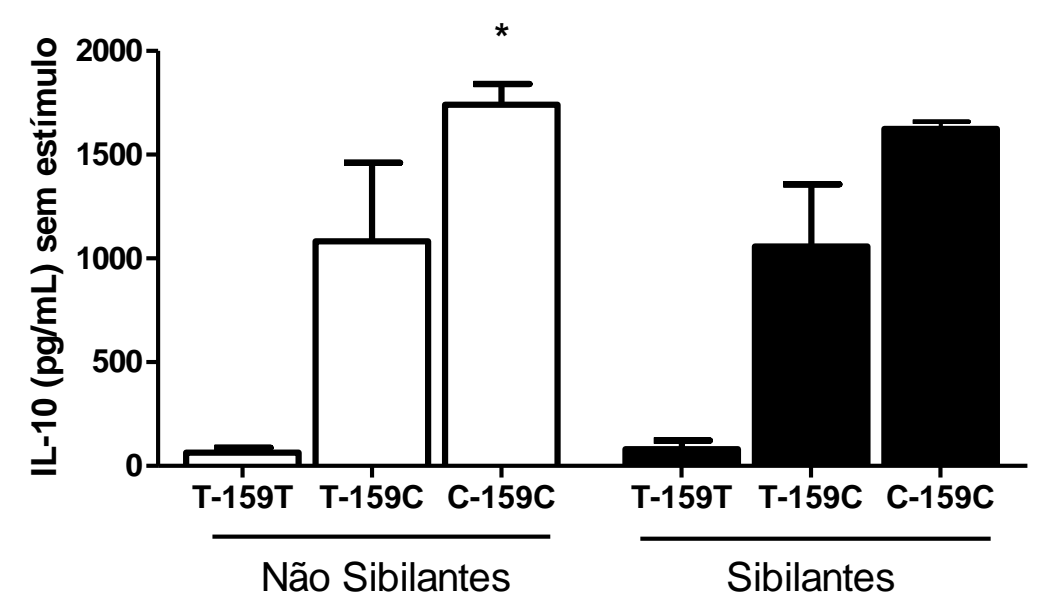

Figura 13. Polimorfismo C159C de CD14 associado com a produção basal de IL-10. Dosagem de citocinas por ELISA. Teste de Fischer, ${ }^{*} \mathrm{p}<0,05$.

\subsection{Desenvolvimento da asma em crianças sibilantes.}

Ao completar cinco anos de seguimento, fizemos a avaliação clínica para determinação do quadro de asma. Observamos que oito crianças não sibilantes e 27 crianças sibilantes desenvolveram o quadro de asma (Fischer, $* * * p=0,0002$; Tabela 8), havendo portanto, maior incidência de asma entre as crianças sibilantes ao final de cinco anos de seguimento.

Tabela 8 - Incidência de asma em crianças Sibilantes e Não sibilantes ao final de cinco anos de seguimento clínico.

\begin{tabular}{cccc}
\hline & Não Sibilantes & Sibilantes & Total \\
\hline Não Asmáticos & 34 & 17 & 51 \\
Asmáticos & 8 & $* * * 27$ & 35 \\
Total & 42 & 44 & 86 \\
\hline
\end{tabular}

Fischer, $* * * \mathrm{p}=0,0002$; OR CI $95 \%=2.531$ to 18.00 


\section{DISCUSSÃO}

A hipótese da higiene defende que a exposição precoce a determinados tipos de infecções, vacinas ou endotoxinas pode influenciar a resposta imunológica e, numa fase mais tardia da vida, diminuir os riscos de desenvolvimento de doenças alérgicas por mecanismos ainda não conhecidos (EDER; VON MUTIUS, 2004). Neste trabalho, seguimos uma coorte de lactentes considerados de alto risco para desenvolver doenças alérgicas, pois são filhos de pais atópicos, que foram classificados de acordo com a intensidade da exposição a endotoxina ambiental nos primeiros seis meses de vida. Nós ainda estudamos a liberação de citocinas por PBMC em resposta a uma estimulação de LPS in vitro, e analisamos eventuais associações entre dados clínicos e laboratoriais.

Vários estudos mostraram que infecções respiratórias recorrentes no inicío da vida são fatores de risco para o desenvolvimento de sibilância (WILSON, 2003). Em nosso trabalho também observamos que infecções respiratórias estão associadas à sibilância (Tabela 3; Fischer, ${ }^{*} \mathrm{p}<0,05$ ), e a maioria dessas crianças sibilantes foram diagnosticadas como asmáticas aos cinco anos de idade (Tabela 8; Fischer, *p<0,05). Esses resultados já eram esperados de acordo com a literatura, que mostra que infecções por vírus respiratórios, principalmente por vírus respiratório sincicial, constituem um fator de risco para sibilância aguda entre crianças com menos de dois anos de idade, sendo a sibilância um fator de risco para asma (RULLO et al., 2009). No entanto, não observamos associação entre a sibilância com eczema, obstrução nasal, tabagismo passivo, exposição a animais domésticos (Tabela 3; Fischer, $\left.{ }^{*} \mathrm{p}<0,05\right)$. Muitos estudos demonstraram que a sibilância na infância é comum, e usualmente associada a características funcionais e anatômicas do pulmão de crianças, eczema, tabaco e exposição a animais domésticos (CHONG NETO et al., 2010).

Outro fator de risco que deve ser levado em consideração para o desenvolvimento de doenças alérgicas é a sensibilização a aeroalérgenos de ambientes internos e externos (PASTORINO et al., 2008). Nossos dados mostram que a resposta aos diferentes tipos de alérgenos é semelhante entre as crianças sibilantes e não sibilantes, sendo que a maioria delas respondeu aos alérgenos de Dermatophagoides pteronyssinus, Blomia tropicalis e Periplaneta americana (Tabela 3; Fischer, *p<0,05). Estudos anteriores realizados no Brasil também demonstraram que crianças sibilantes são mais sensíveis aos alérgenos de D. pteronyssinus, D. farinae e Blomia tropicalis, 
não tendo diferença com relação à distribuição por faixa etária, entre crianças abaixo de 2 anos até 12 anos (PASTORINO et al., 2008).

A sensibilização aos alérgenos também está relacionada com o grau de exposição ambiental do mesmo e um fator agravante para sensibilização e para o desenvolvimento da sibilância e das doenças alérgicas, a exposição à endotoxina. Vários estudos investigam a importância da exposição à endotoxina no desenvolvimento da sibilância (BAYARDELLE, 2003). Alguns autores demonstram que a exposição à alta concentração de endotoxina durante o primeiro ano de vida diminui o risco de desenvolvimento de asma e alergias (MICHEL et al., 1991; DOUWES et al., 2002; CELEDON et al., 2007), ao passo que outros autores relatam aumentar o risco de desenvolvimento dessas doenças (BERTELSEN et al., 2010). Entretanto, alguns estudos demonstraram que a concentração de endotoxina no ambiente não se associou com a sensibilização alérgica (YILMAZ et al., 2009). Dentro desse contexto avaliamos os efeitos da exposição ambiental à endotoxina no desenvolvimento do fenótipo de sibilância e no padrão de citocinas produzidas por PBMCs frente ao estímulo in vitro com LPS. Nossos dados mostram que a exposição à endotoxina no início da vida não influenciou na sibilância desenvolvida aos 30 meses de idade (Tabela 3 e Figura 2; Fischer, $\left.{ }^{*} \mathrm{p}<0,05\right)$. Estes resultados contradizem os da literatura que mostram que a exposição às altas concentrações de endotoxina diminui o risco de desenvolvimento de sibilância em crianças lactentes (GILLESPIE et al., 2006).

A exposição à endotoxina, apesar de não ter apresentado correlação com o desenvolvimento do fenótipo da sibilância, pode alterar outros mecanismos imunológicos importantes envolvidos com a sibilância, tais como a produção de citocinas. Sabemos que o LPS é reconhecido pelo complexo CD14, TLR4 e MD2, que ativa vias de sinalização, fatores de transcrição que promovem a transcrição de diversos genes, inclusive os genes que codificam essas citocinas (SIMPSON; MARTINEZ, 2010). O balanço na produção de citocinas constitui um ponto importante no desenvolvimento e estabelecimento de doenças alérgicas (YAO et al., 2010). Para tanto, separamos os PBMC, estimulamos com LPS e dosamos TNF- $\alpha$, IL-17, IL-10, IL-4, IL5, IL-12p70 e IFN- $\gamma$.

A produção de TNF- $\alpha$, IL-10, IL-17, IL-4 e IL-5 por PBMC de crianças sibilantes e não sibilantes estimuladas in vitro com LPS foram similares em ambos os grupos independentemente dos níveis de exposição a endotoxina ambiental durante os primeiros seis meses de vida (Figuras 5 a 8; Mann-Whitney, p>0,05). Nós também 
observamos que a exposição precoce a níveis de endotoxina acima de 50 EU/mg está associada à produção de quantidades maiores de IL-12 e IFN- $\gamma$ por PBMC de crianças não sibilantes, o que não foi observada no grupo de exposto à níveis de endotoxina abaixo de 50 EU/mg (Figuras 3 e 4; Mann Whitney, *p<0,05). Estes resultados sugerem uma perspectiva de efeito protetor da exposição precoce à endotoxina, uma vez que o aumento da resposta Th1 tem sido apontada como ponto-chave para evitar o desenvolvimento de sintomas alérgicos e sibilância.

Por outro lado, observamos que PBMC de crianças sibilantes produzem quantidades menores de IL-12p70 e IFN- $\gamma$, de uma forma independente da exposição à endotoxina ambiental (Figuras 3 e 4; Mann Whitney, ${ }^{*} \mathrm{p}<0,05$ ). Um estudo envolvendo o balanço entre IL-4 e IFN- $\gamma$ em síndrome de IgE (PAGANELLI et al., 1991) sugere que uma causa possível do desenvolvimento de doenças alérgicas decorre de um defeito na resposta IL-12/IFN- $\gamma$ e não de uma resposta excessiva de IL-4/IL-5. Outro estudo mostrou uma resposta polarizada para um padrão Th2, com menores níveis de IL-12 e uma proporção maior de IL-10/IL-12 no soro de crianças que desenvolveram chiado no primeiro ano de vida (KOOPMAN et al., 2003). Mais uma evidência de que a diminuição do padrão Th1 de citocinas é o fato de que recém-nascidos que posteriormente desenvolveram bronquiolite apresentaram baixos níveis de IL-12 no sangue de cordão umbilical quando comparado com crianças que não desenvolveram a doença (BLANCO-QUIROS et al., 1999).

Interessantemente, observamos que crianças não sibilantes liberam maior quantidade de IL-12 e IFN- $\gamma$ em resposta ao LPS quando comparados com crianças sibilantes. Esta maior produção pode justificar a baixa incidência de infecções respiratórias em crianças não sibilantes. Uma vez que o eixo IL-12/IFN- $\gamma$ parece apresentar uma "falha" na sua ativação nas crianças sibilantes, há um maior risco de respostas inadequadas e ineficazes de linfócitos e fagócitos a patógenos (TRINCHIERI, 2003). A importância dessa baixa produção de IL-12 e IFN- $\gamma$ associada às infecções fica mais evidente no contexto da sibilância, quando levamos em consideração o fato de não observarmos associação dessa patogenia com atopia.

Juntamente com essas respostas funcionais, a análise de genes chave, como dos receptores TLR4 e CD14, é importante para investigar detalhes do desenvolvimento de sibilância, principalmente em relação à exposição a endotoxina. Em nosso trabalho, analisando polimorfismos nos genes codificantes de CD14 e TLR4, os resultados sugerem que estes polimorfismos não estão associados ao fenótipo de sibilância 
(Tabelas 4 e 5; Fischer, p>0,05). A associação de polimorfismos desses receptores com a sibilância e doenças alérgicas é controversa, tendo autores demonstrado que estes polimorfismos estão associados ao desenvolvimento de sibilância (LEVAN et al., 2005; NUOLIVIRTA et al., 2009), enquanto outros demonstraram que não existe essa associação (NUOLIVIRTA et al., 2009).

Além da associação entre fenótipo e genótipo, avaliamos se o polimorfismo no gene codificante de CD14 (C-159T) está associado à sensibilização aos diferentes alérgenos. Observamos que as crianças com genótipo polimórfico T-159T foram mais sensíveis aos alérgenos de barata e fungos (Tabelas 6 e 7; Fischer, ${ }^{*} p<0,05$ ). Vale ressaltar que as baratas são importantes agentes de sensibilização especialmente em pacientes de áreas urbanas e com baixo nível socioeconômico, característica da nossa população de estudo. Estudos anteriores demonstraram que 20 a $60 \%$ da população em geral está sensibilizada a este alérgeno e que no Brasil 20 a 32,6\% da população é sensibilizada ao alérgeno de barata (CAMELO-NUNES; SOLE, 2006; PERZANOWSKI; PLATTS-MILLS, 2009). Pode ser que esta alta positividade deva-se a associação encontrada com o polimorfismo do gene de CD14. A positividade aos alérgenos de fungos é relativamente baixa quando comparada com outros alérgenos. Portanto, este resultado sugere que o CD14 é importante para a resposta imune a fungos, uma vez que muitas espécies de fungos são potencialmente implicadas no desencadeamento de doenças alérgicas (AGARWAL; GUPTA, 2010). A associação entre o polimorfismo de CD14 e os outros alérgenos não foi encontrada em nosso estudo.

Também investigamos a possível associação entre o polimorfismo no gene de CD14 e produção de citocinas por PBMC estimuladas ou não com LPS, em ambos os grupos de sibilantes e não sibilantes. Pudemos observar que a baixa produção de IL-12 não está relacionada com os polimorfismos nos genes de CD14 (C-159T) e TLR4 (Asp299Gly) (Tabelas 4 e 5; Fischer, p>0,05). No entanto, observamos que PBMC de crianças não sibilantes que apresentaram o genótipo polimórfico produziram quantidades elevadas de IFN- $\gamma$ e IL-10 sem estímulo de LPS (Figuras 12 e 13; Fischer, *p<0,05). Uma possível explicação para esses dados está no fato de indivíduos que possuem esse polimorfismo apresentarem baixas quantidades de CD14 solúvel no soro (MUNTHE-KAAS et al., 2010). O CD14 solúvel regula negativamente a ativação e função de linfócitos $\mathrm{T}$, interagindo diretamente com as células T ativadas (REY NORES et al., 1999). Essa falta de regulação dos linfócitos T pelo CD14 solúvel pode ser a 
causa de encontramos essa alta produção de IFN- $\gamma$ e IL-10, citocinas liberadas por linfócitos Th1 e Treg. A associação entre esse polimorfismo e a produção de IL-4, IL-5, IL-17, IL-12 e TNF- $\alpha$ não foi encontrada em nosso estudo.

Após as evidências encontradas em relação aos polimorfismos e produção de citocinas cabe perguntar: seria a liberação de IL-12 e IFN- $\gamma$ um fator de proteção contra a sibilância no início da infância? A resposta a esta questão vai determinar, no futuro, a continuação do nosso e de outros estudos. Nesse ponto pretendemos investigar a presença de distúrbio permanente ou transitório molecular nas células de crianças sibilantes. Para tanto é necessário estudar polimorfismos de IL-12 e IFN- $\gamma$ e seus receptores, além do padrão de expressão desses receptores e suas vias de sinalização intracelulares. Esse conjunto de dados pretende contribuir para o avanço do conhecimento sobre a regulação da resposta imune e desenvolvimento da sibilância e asma na infância. 


\section{CONCLUSÕES PARCIAIS}

1. Infecções respiratórias estão associadas ao desenvolvimento de sibilância.

2. Crianças sibilantes e não sibilantes sensibilizaram-se com frequiência similar e principalmente por Dermatophagoides pteronyssinus, Blomia tropicalis e Periplaneta americana.

3. A exposição à endotoxina ambiental no início da vida não teve um papel essencial no desenvolvimento do quadro de sibilância.

4. As PBMC de crianças sibilantes apresentam menor produção de citocinas Th1, IFN- $\gamma /$ IL-12 comparadas a crianças não sibilantes, independente do nível de exposição precoce a endotoxina e independente do tratamento in vitro dessas células com LPS.

5. Os polimorfismos nos genes de TLR4 (Asp299Gly) e CD14 (C-159T) não estão associados ao fenótipo da sibilância.

6. O polimorfismo no gene de CD14 (C-159T) está associado com a sensibilização ao alérgenos de Periplaneta americana e de fungos.

7. O polimorfismo no gene de CD14 (C-159T) está associado a uma maior produção espontânea de IFN- $\gamma$ e IL-10 por PBMC de crianças não sibilantes. 


\section{PARTE II}

\section{OBJETIVOS}

Avaliar a ativação celular de PBMC de crianças asmáticas leves, moderadas e graves, em resposta à estimulação in vitro com LPS

\subsection{Objetivos específicos}

A) Analisar os dados clínicos de crianças com idade entre 5 e 18 anos definidas como não asmáticas (controle), asmáticas leves, moderadas e graves;

B) Avaliar a sensibilização atópica no grupo por meio de teste cutâneo de hipersensibilidade imediata (prick test);

C) Avaliar a produção de citocinas (TNF- $\alpha$, IL-10, IL-12, IFN- $\gamma$, IL-4, IL-5 e IL17) liberadas por PBMC de crianças asmáticas e não asmáticas mediante estimulação com LPS;

D) Investigar a prevalência dos polimorfismos CD14 (T-159C) e TLR4 (Asp299Gly) em crianças asmáticas e não asmáticas;

E) Analisar as possíveis associações entre esses parâmetros. 


\section{MATERIAIS E MÉTODOS}

\subsection{Casuística}

Para o estudo de crianças com asma definida, foram selecionadas 86 crianças com idade entre 5 e 18 anos. O quadro clínico de asma foi diagnosticado segundo as normas descritas pelo GINA (Global Initiative for Asthma). Estes critérios levam em consideração um ou mais sintomas como: dispnéia, tosse crônica, sibilância, aperto no peito ou desconforto torácico, particularmente à noite ou nas primeiras horas da manhã; melhora espontânea ou pelo uso de medicações específicas para asma (broncodilatadores, antiinflamatórios esteróides); três ou mais episódios de sibilância no último ano; variabilidade sazonal dos sintomas e história familiar positiva para asma ou atopia; e diagnósticos alternativos excluídos. Para descrição desses parâmetros foi aplicado um questionário aos pais ou responsáveis legais (ANEXO E). O diagnóstico funcional foi fundamentado pela presença de sintomas característicos, sendo confirmado pela demonstração de limitação variável ao fluxo de ar. As medidas da função pulmonar fornecem uma avaliação da gravidade da limitação ao fluxo aéreo, sua reversibilidade e variabilidade, além de confirmar o diagnóstico de asma.

Os pais ou responsáveis legais das crianças envolvidas no estudo deram seu consentimento informado, e todos os procedimentos aqui descritos não ultrapassam os limites de risco mínimo de acordo com a regulamentação da Convenção de Helsinki para pesquisa com seres humanos e do Conselho Nacional de Saúde. As cópias da aprovação do projeto de pesquisa pelas Comissões de Ética em Pesquisa do ICB-USP e da UNIFESP encontram-se nos ANEXOS A, B e C.

\subsection{Teste cutâneo de hipersensibilidade}

Vide item materiais e métodos parte I

\subsection{Obtenção e cultura de PBMC}

Vide item materiais e métodos parte I 
8.4 Extração de DNA e Análise de Polimorfismos nos genes de CD14 (-159)

e TLR4 (299)

Vide item materiais e métodos parte I

\subsection{Dosagem de citocinas}

Vide item materiais e métodos parte I

\subsection{Análises Estatísticas}

Vide item materiais e métodos parte I 


\section{RESULTADOS}

\subsection{Dados clínicos}

O estudo incluiu 86 crianças com idade de 5 e 18 anos, sendo 17 crianças não asmáticas, 27 asmáticas leves, 26 moderadas e 16 graves, dentre eles 48 meninos e 38 meninas. O teste de hipersensibilidade mostrou que as crianças asmáticas foram sensibilizadas principalmente por Dermatophagoides pteronyssinus, Blatella germanica e D. fariane (Fischer, $\mathrm{p}>0,05$; Tabela 9).

Tabela 9 - Dados clínicos de 86 crianças asmáticas e não asmáticas.

\begin{tabular}{ccccc}
\hline Não Asmáticos & $\begin{array}{c}\text { Asmáticos } \\
\text { Leves }\end{array}$ & $\begin{array}{c}\text { Asmáticos } \\
\text { Moderados }\end{array}$ & $\begin{array}{c}\text { Asmáticos } \\
\text { Graves }\end{array}$ \\
\hline $\begin{array}{c}\text { Número de } \\
\text { Indivíduos }\end{array}$ & 17 & 27 & 26 & 16 \\
Raça & Miscigenados & Miscigenados & Miscigenados & Miscigenados \\
Sexo & & & & \\
Meninos & 8 & 18 & 14 & 8 \\
Meninas & 9 & 9 & 12 & 8 \\
Sensibilização & & & 20 & 8 \\
D. pteronyssinus & ND & 17 & 9 & 5 \\
D. farinae & ND & 10 & 11 & 4 \\
B. tropicalis & ND & 11 & 2 & 1 \\
Fungos (mix) & ND & 3 & 4 & 0 \\
\hline Antígenos de Cão & ND & 4 & 2 & 0 \\
\hline Antígenos de Gato & ND & 6 & 0 & \\
\hline Alimentos & ND & 2 & & \\
\hline
\end{tabular}

ND: Não detectado (Prick test não foi realizado nesse grupo).

\subsection{Produção de citocinas por PBMC estimuladas com LPS de crianças} asmáticas leves, moderadas e graves e não asmáticas

A ativação celular de PBMC em resposta à estimulação in vitro com LPS em crianças não asmáticas (controle), asmáticas leves, moderadas e graves foi avaliada 
através da produção de citocinas de padrão Th1 (IL-12p70 e IFN- $\gamma$ ), inflamatório (TNF$\alpha$ e IL-17), regulatório (IL-10) e Th2 (IL-4 e IL-5).

\subsubsection{Produção de IL-12p70 e IFN-y por PBMC estimuladas com LPS} de crianças asmáticas e não asmáticas

PBMC estimuladas com e sem LPS de crianças asmáticas graves produziram baixas quantidades de IL-12p70 quando comparado com PBMC de crianças não asmáticas (Mann-Whitney, ${ }^{*} p<0,05, * * p<0,005$; Figura 14). PBMC de crianças asmáticas leves produziram baixas quantidades de IFN- $\gamma$ sem estímulo quando comparado com PBMC de crianças não asmáticas (Mann-Whitney, ${ }^{*} \mathrm{p}<0,05$; Figura 15).

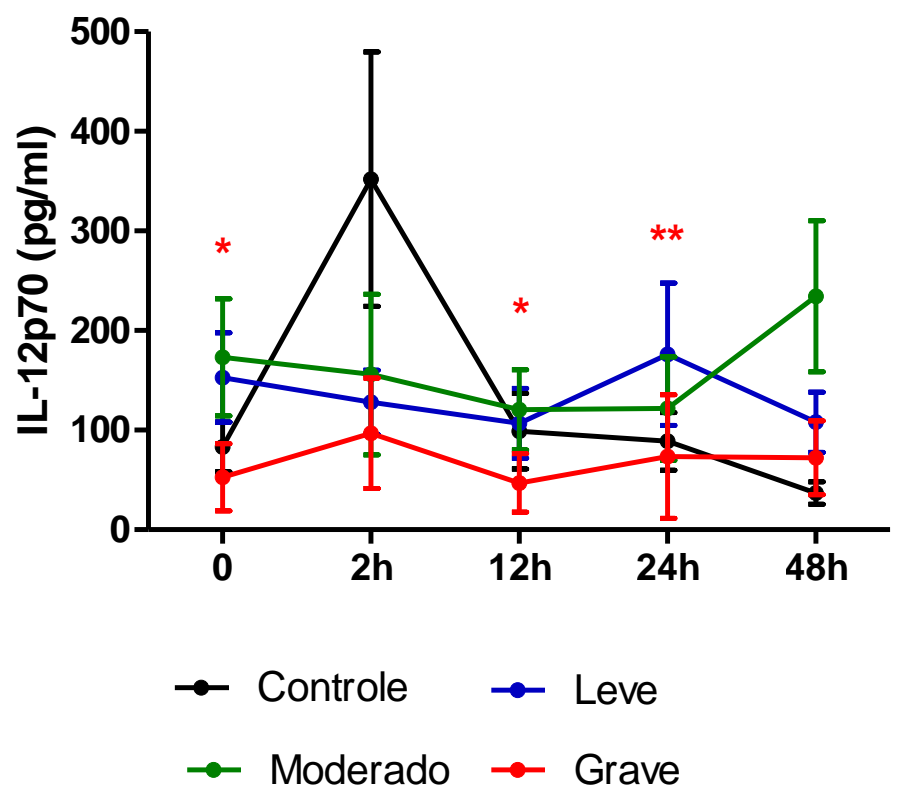

Figura 14. Produção de IL-12p70 por PBMC de crianças asmáticas e não asmáticas. PBMC de crianças asmáticas graves produziram baixos níveis de IL-12p70 com e sem estímulo de LPS quando comparadas com o grupo controle. (Controle $n=13$; Leve $n=19$; Moderado $n=16$ e Grave $n=13$ ). Mann-Whitney, ${ }^{*} p<0,05$ e $* * p<0.005$. 


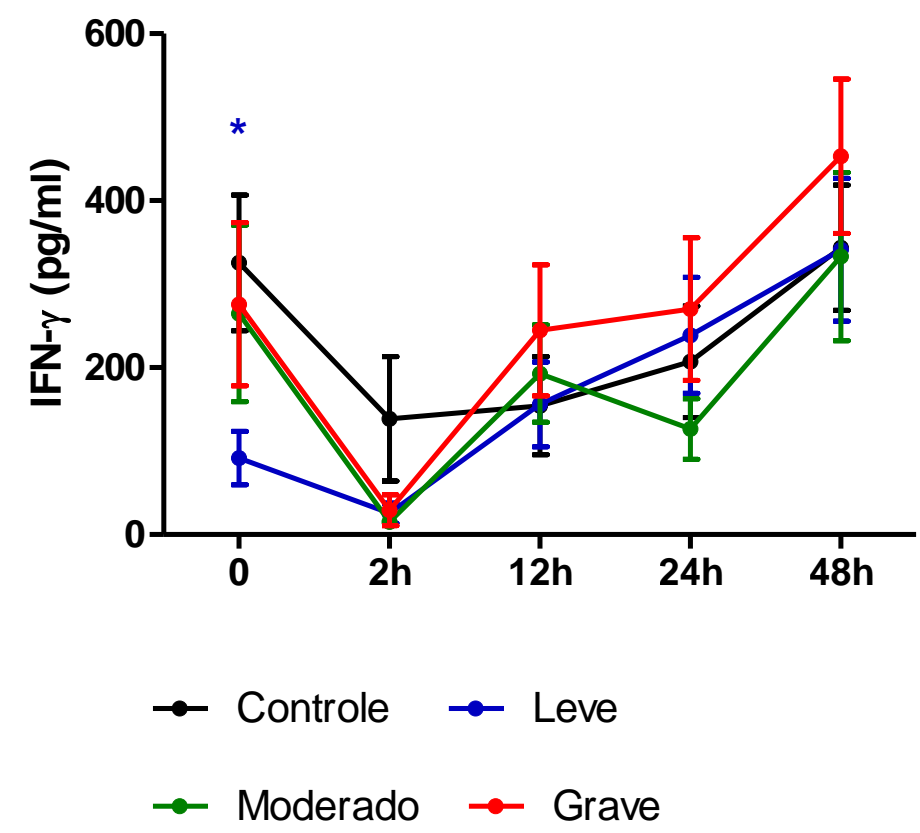

Figura 15. Produção de IFN- $\gamma$ por PBMC de crianças asmáticas e não asmáticas. PBMC de crianças asmáticas leves produziram baixos níveis de IFN- $\gamma$ sem estímulo de LPS quando comparadas com o grupo controle (Controle $n=15$; Leve $n=16$; Moderado $\mathrm{n}=14$ e Grave $\mathrm{n}=10)$.Mann-Whitney, * $\mathrm{p}<0,05$.

9.2.2 Produção de TNF- $\alpha$, IL-17 e IL-10 por PBMC estimuladas com LPS de crianças asmáticas e não asmáticas

PBMC de crianças asmáticas e não asmáticas produziram quantidades semelhantes de TNF- $\alpha$, mesmo após estímulo com LPS (Mann-Whitney, p>0,05; Figura 16). PBMC de crianças asmáticas moderadas produziram baixas quantidades de IL-17 e IL-10 sem estímulo com LPS quando comparado com PBMC de crianças não asmáticas (Mann-Whitney, *p<0,05; Figuras 17 e 18). 


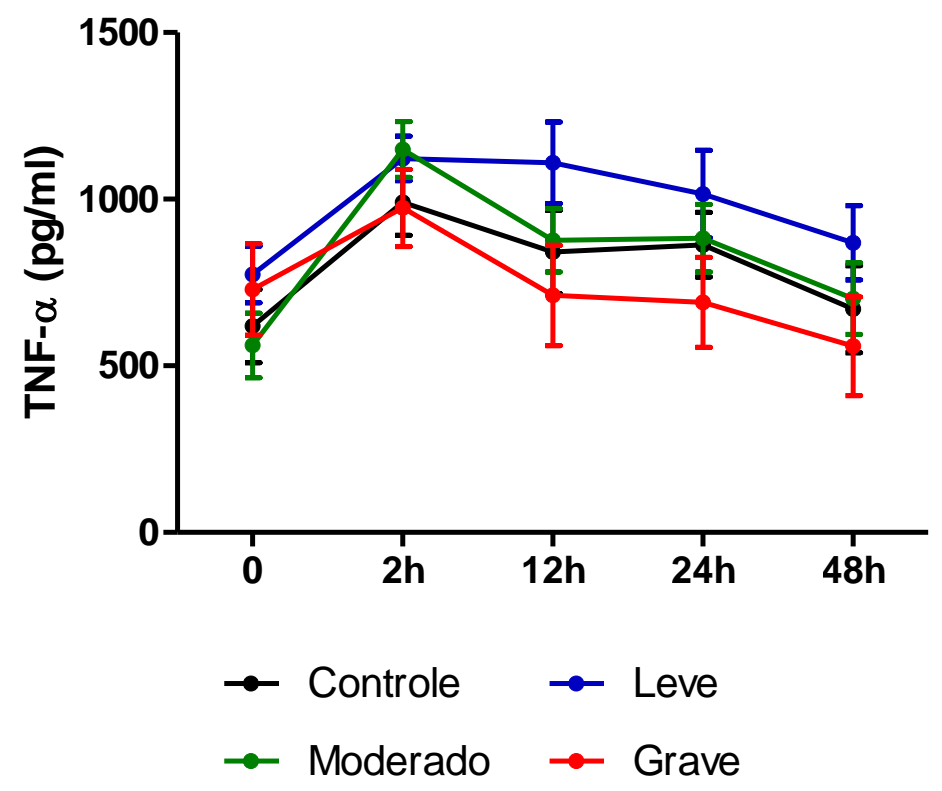

Figura 16. Produção de TNF- $\alpha$ por PBMC de crianças asmáticas e não asmáticas. PBMC de crianças asmáticas e não asmáticas produziram quantidades similares de TNF- $\alpha$, mesmo após estímulo de LPS (Controle $n=15$; Leve $n=15$; Moderado $n=14$ e Grave $\mathrm{n}=10$ ). Mann-Whitney, ${ }^{*} \mathrm{p}<0,05$.

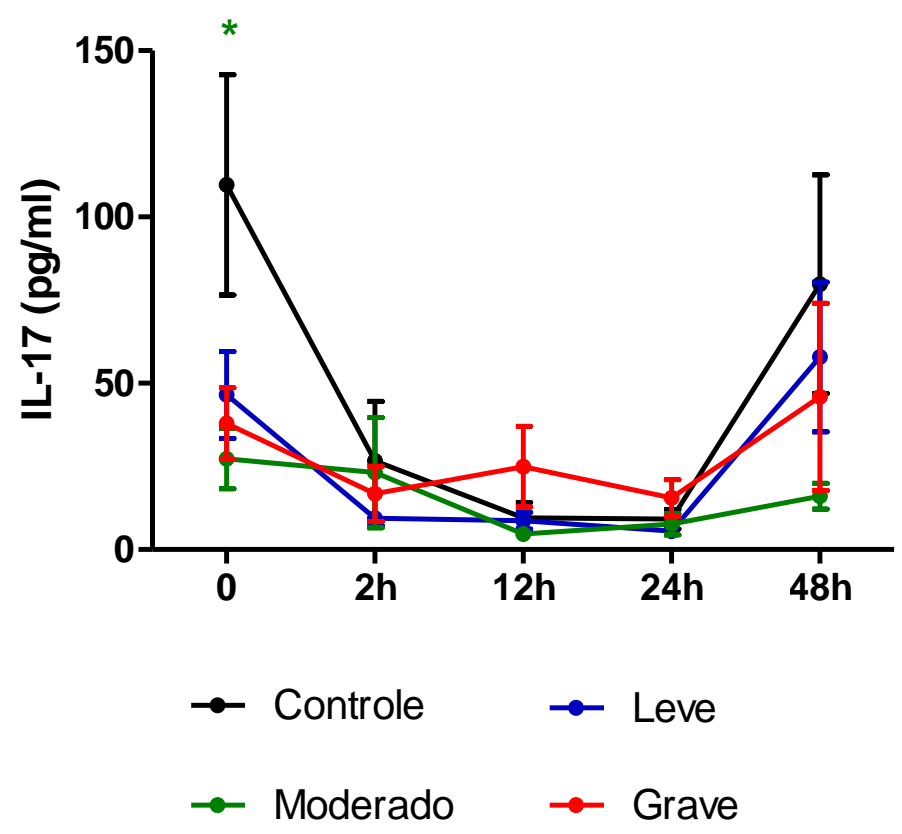

Figura 17. Produção de IL-17 por PBMC de crianças asmáticas e não asmáticas. PBMC de crianças asmáticas moderadas produziram baixos níveis de IL-17 sem estímulo de LPS quando comparadas com o grupo controle (Controle $\mathrm{n}=16$; Leve $n=16$; Moderado $n=15$ e Grave $n=14)$. Mann-Whitney, *p<0,05. 


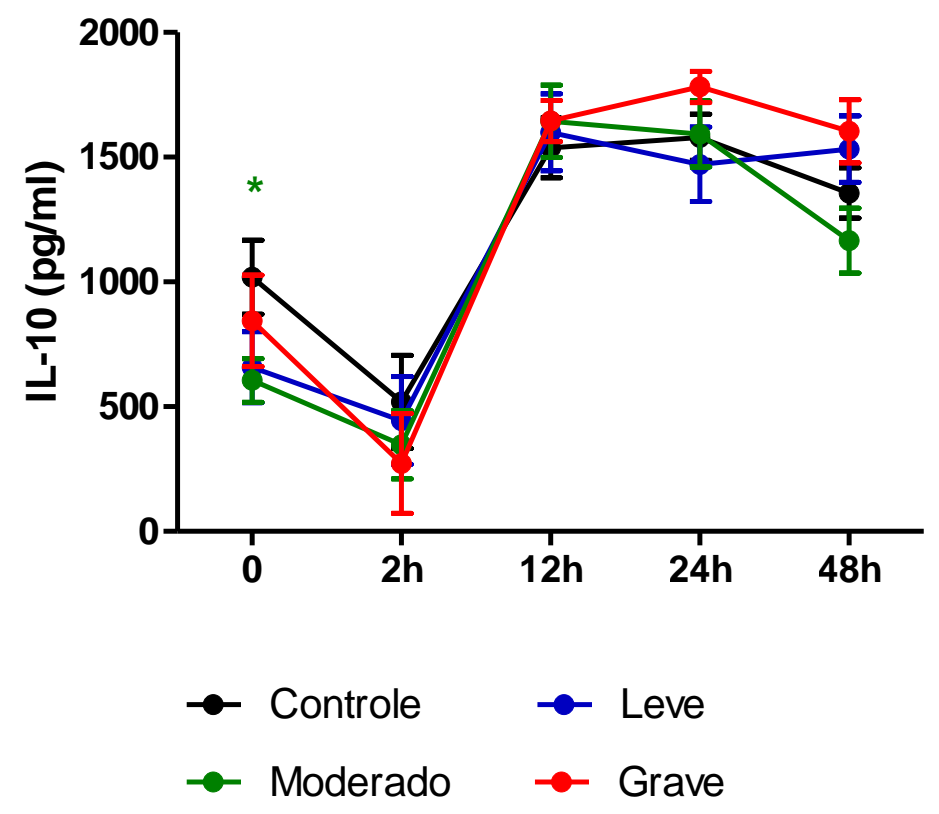

Figura 18. Produção de IL-10 por PBMC de crianças asmáticas e não asmáticas. PBMC de crianças asmáticas moderadas produziram baixos níveis de IL-10 sem estímulo de LPS quando comparadas com o grupo controle (Controle $n=16$; Leve $n=17$; Moderado $n=14$ e Grave $n=10)$. Mann-Whitney, ${ }^{*} p<0,05$.

9.2.3 Produção de IL-4 e IL-5 por PBMC estimuladas com LPS de crianças asmáticas e não asmáticas

PBMC de crianças asmáticas leves, moderadas e graves produziram baixas quantidades de IL-4 após estímulo com LPS quando comparado com PBMC de crianças não asmáticas (Mann-Whitney, $* p<0,05$; Figura 19). PBMC de crianças asmáticas leves produziram altas quantidades de IL-5 sem estímulo de LPS quando comparado com PBMC de crianças não asmáticas (Mann-Whitney, ${ }^{*} \mathrm{p}<0,05$; Figura 20). 


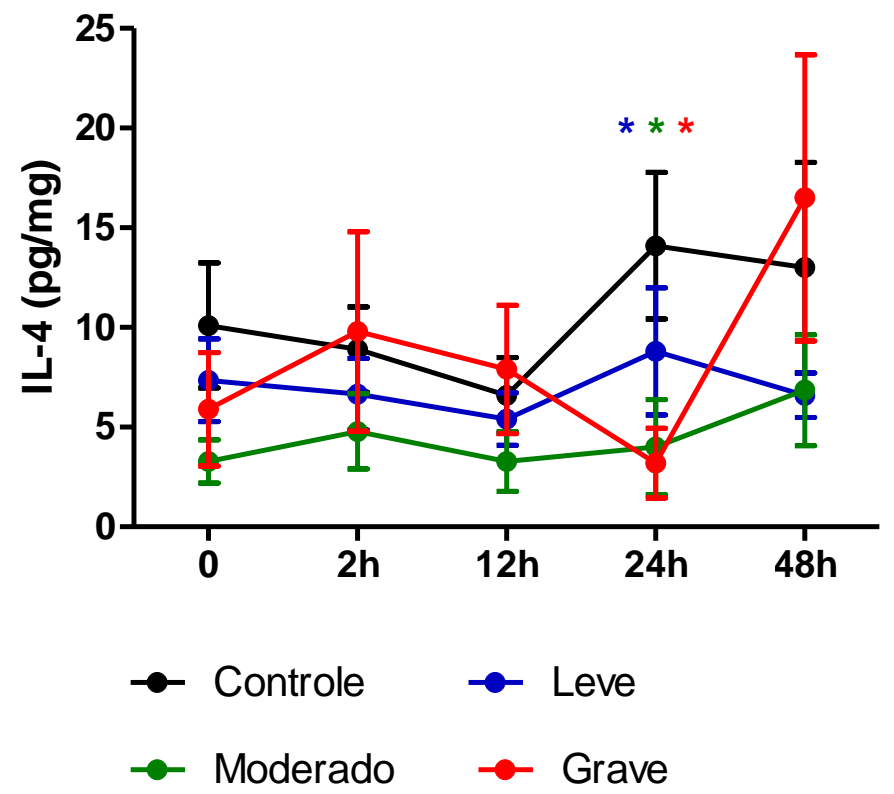

Figura 19. Produção de IL-4 por PBMC de crianças asmáticas e não asmáticas. PBMC de crianças asmáticas leves, moderadas e graves produziram baixos níveis de IL-4 após estímulo com LPS quando comparadas com o grupo controle (Controle $n=10$; Leve $n=20$; Moderado $n=14$ e Grave $n=10$ ). MannWhitney, ${ }^{*} \mathrm{p}<0,05$.

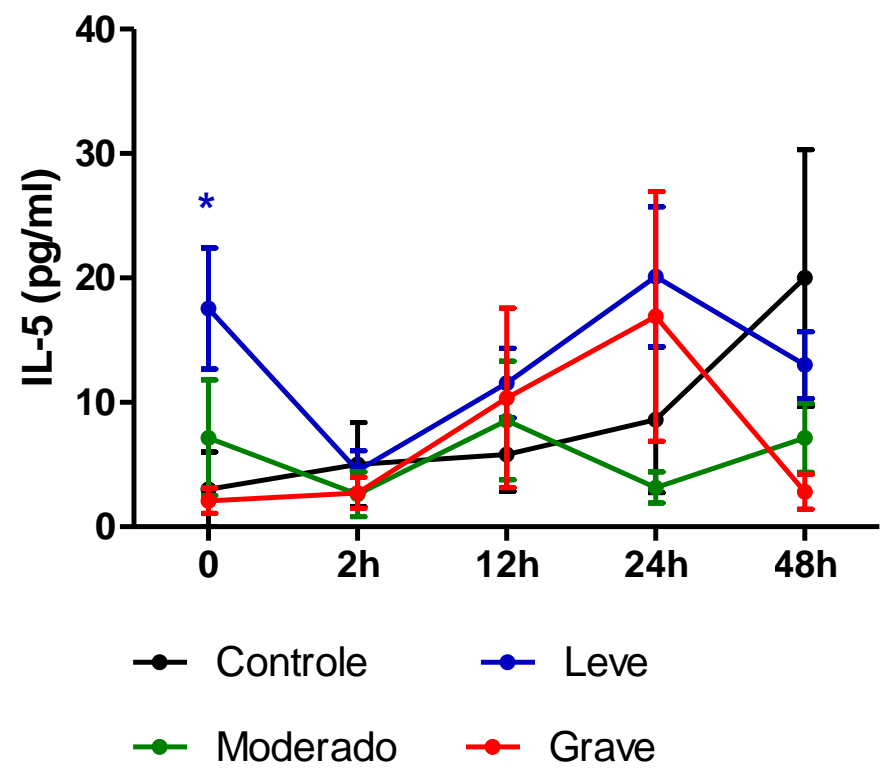

Figura 20. Produção de IL-5 por PBMC de crianças asmáticas e não asmáticas. PBMC de crianças asmáticas leves produziram altos níveis de IL-5 sem estímulo de LPS quando comparadas com o grupo controle (Controle $n=10$; Leve $n=20$; Moderado $n=13$ e Grave $n=11$ ). Mann-Whitney, ${ }^{*} \mathrm{p}<0,05$. 
9.3 Polimorfismos nos genes de TLR4 e CD14, receptores envolvidos no reconhecimento de LPS

Para análises do polimorfismo de CD14 foram avaliados 120 indivíduos, sendo 61 não asmáticos, 24 indivíduos asmáticos leves, 22 indivíduos asmáticos moderados e 13 indivíduos asmáticos graves. Além das 17 crianças não asmáticas do início dos experimentos, foram adicionados 44 indivíduos não asmáticos, para aumentarmos o número de indivíduos controle. Observamos que 100\% das crianças não asmáticas e asmáticas apresentaram o genótipo não polimórfico D299D (Fischer, p>0,05; Tabela 10). Portanto $100 \%$ das crianças apresentaram o alelo 299D. A porcentagem dos genótipos e alelos entre os grupos não variou de forma estatisticamente significativa (Fischer, $\mathrm{p}>0,05$; Tabela 10).

Tabela 10 - Polimorfismo de TLR4 em crianças asmáticas leves, moderadas e graves.

\begin{tabular}{ccccc}
\hline Genótipos & $\begin{array}{c}\text { Não } \\
\text { Asmáticos }\end{array}$ & $\begin{array}{c}\text { Asmáticos } \\
\text { Leves }\end{array}$ & $\begin{array}{c}\text { Asmáticos } \\
\text { Moderados }\end{array}$ & $\begin{array}{c}\text { Asmáticos } \\
\text { Graves }\end{array}$ \\
\hline D299D & $61(100)$ & $24(100)$ & $22(100)$ & $13(100)$ \\
D299G & $0(0,0)$ & $0(0,0)$ & $0(0,0)$ & $0(0,0)$ \\
G299G & $0(0,0)$ & $0(0,0)$ & $0(0,0)$ & $0(0,0)$ \\
Total & 61 & 24 & 22 & 13 \\
Alelos & & & & $26(100)$ \\
D & $122(100)$ & $48(100)$ & $44(100)$ & $0(0,0)$ \\
G & $0(0,0)$ & $0(0,0)$ & $0(0,0)$ & 26 \\
\hline Total & 122 & 48 & 44 & \\
\hline
\end{tabular}

Para análises do polimorfismo de CD14 foram avaliada 123 indivíduos, sendo 63 não asmáticos, 25 asmáticos leves, 22 asmáticos moderados e 13 asmáticos graves. Além das 17 crianças não asmáticas do início dos experimentos, foram adicionados 46 indivíduos adultos não asmáticos, para aumentarmos o número de indivíduos controle. Nos grupos não asmáticos, asmáticos leves, moderados e graves, respectivamente, 
observamos que 48,28\%,10,14\%, 13,79\% e 13,79\% dos indivíduos apresentaram o genótipo C-159C, que 53,62\%, 18,84\%, 18,84\% e 8,70\% dos indivíduos apresentaram o genótipo C-159T, e que 48\%, 20\%, 20\% e 12\% dos indivíduos apresentaram o genótipo T-159T (Fischer, p>0,05; Tabela 10). Portanto, nos grupos não asmáticos, asmáticos leves, moderados e graves respectivamente, observamos que 51,59\%, 54\%, 47,73\% e $53,85 \%$ dos indivíduos apresentaram o alelo $-159 \mathrm{C}$ e que $48,41 \%, 46 \%, 52,27 \%$ e 46,15\% dos indivíduos apresentaram o alelo -159T. A porcentagem dos genótipos e alelos entre os grupos não variou de maneira estatisticamente significativa (Fischer, $\mathrm{p}=0,93$; Tabela 11).

Tabela 11 - Polimorfismo de CD14 em crianças asmáticas leves, moderadas e graves.

\begin{tabular}{ccccc}
\hline & $\begin{array}{c}\text { Não } \\
\text { Asmáticos }\end{array}$ & $\begin{array}{c}\text { Asmáticos } \\
\text { Leves }\end{array}$ & $\begin{array}{c}\text { Asmáticos } \\
\text { Moderados }\end{array}$ & $\begin{array}{c}\text { Asmáticos } \\
\text { Graves }\end{array}$ \\
\hline Genótipos & & & & \\
C-159C & $14(48,28)$ & $7(10,14)$ & $4(13,79)$ & $4(13,79)$ \\
C-159T & $37(53,62)$ & $13(18,84)$ & $13(18,84)$ & $6(8,70)$ \\
T-159T & $12(48)$ & $5(20)$ & $5(20)$ & $3(12)$ \\
Total & 63 & 25 & 22 & 13 \\
$\underline{\text { Alelos }}$ & & $27(54)$ & $21(47,73)$ & $14(53,85)$ \\
C & $65(51,59)$ & $23(46)$ & $23(52,27)$ & $12(46,15)$ \\
T & $61(48,41)$ & 50 & 44 & 26 \\
\hline Total & 126 & 5 & & \\
\hline
\end{tabular}

Como realizado nas crianças sibilantes, também avaliamos se o polimorfismo de CD14 está associado com a sensibilização aos alérgenos e com a produção de citocinas por PBMC, estimuladas ou não com LPS de crianças asmáticas. Pudemos observar que o polimorfismo de CD14 está associado com sensibilização aos alérgenos de fungos (Fischer, **p<0.001; Tabela 12). Não foi possível realizar a associação com o alérgeno Per a1, uma vez que não foi feito o teste cutâneo para este antígeno. Quanto 
à produção de citocinas, o número de indivíduos foi insuficiente em cada grupo para se fazer a análise estatística.

Tabela 12 - Polimorfismo C-159T no gene de CD14 associado com sensibilização a alergenos de fungos.

\begin{tabular}{ccc}
\hline Fungos & Não sensível & Sensível \\
\hline Genótipos & n/porcentagem & n/porcentagem \\
\hline T-159T & $8(23)$ & $0(0)$ \\
C-159T & $22(64)$ & $1(25)$ \\
C-159C & $4(11)$ & $3(75)$ \\
Total & 34 & 4 \\
\hline
\end{tabular}




\section{DISCUSSÃO}

A asma é uma doença complexa e multifatorial e para dar continuidade aos nossos estudos analisamos um dos principais aspectos relacionado a funções celulares, a produção de citocinas (HARGREAVE; NAIR, 2009). Todo processo inflamatório, agudo ou crônico, é modulado positiva ou negativamente por citocinas, portanto, caracterizamos o padrão de produção de citocinas após estímulo com LPS, o qual é importante para a regulação e/ou desenvolvimento da resposta inflamatória no contexto da asma.

O teste cutâneo de hipersensibilidade realizado nas crianças asmáticas leves, moderadas e graves confirma os resultados vistos em crianças sibilantes e não sibilantes, uma sensibilidade maior aos alérgeno de Dermatophagoides pteronyssinus e Blomia tropicalis (Tabela 9; Fischer, p>0,05). Esse resultado mostra uma contínua exposição dos pacientes ao ácaro, o que contribui para a manutenção da sensibilização e padrão de resposta desenvolvida. Isso é muito importante, pois a maturação do sistema imune é caracterizada pelo desenvolvimento balanceado entre uma resposta Th1 e Th2, cuja eficiência e a cinética deste processo são determinadas hereditariamente e sob influência do ambiente (ERB; LE GROS, 1996; MATRICARDI; BONINI, 2000; MATRICARDI et al., 2000). Uma vez que há contínua exposição a esses alérgenos, aumenta a possibilidade da manutenção de uma resposta Th2 alérgeno-específica e desenvolvimento de asma.

Como descrito anteriormente os monócitos/macrófagos possuem receptores TLR4/CD14, que são estimulados eficientemente por LPS, constituindo uma importante fonte de citocinas pró-inflamatórias, como TNF- $\alpha$ (TAMANDL et al., 2003). De acordo com a literatura o papel das citocinas pró-inflamatórias em doenças alérgicas se correlaciona com a gravidade da doença (IYODA et al., 2010), sendo o TNF- $\alpha$ uma das mais importantes. Estudos anteriores com crianças asmáticas mostram uma alta concentração dessa citocina em lavados broncoalveolares (PUTHOTHU et al., 2009). Assim como para as crianças sibilantes e não sibilantes, observamos que PBMC de crianças asmáticas e não asmáticas produziram quantidades semelhantes de TNF- $\alpha$ com e sem estímulo de LPS (Figura 16; Mann Whitney<p<0,05). In vivo esses monócitos ou macrófagos alveolares podem liberar TNF- $\alpha$, não só pelo estímulo por LPS, mas também pela exposição aos alérgenos via receptores $\operatorname{IgE}$ de baixa afinidade (FceRII) (VECCHIARELLI et al., 1994). Esta citocina pode atuar sequencialmente sobre as 
células epiteliais que passam a liberar outras citocinas, como IL-5, IL-8 e RANTES, as quais por sua vez amplificam a resposta inflamatória, conduzindo ao influxo de outras células como os eosinófilos, os quais também passam a liberar múltiplas citocinas, constituindo o quadro inflamatório alérgico (LAMPINEN et al., 2001).

A IL-17, como uma citocina pró-inflamatória, também possui um papel importante na patogênese da asma, pois ela é fundamental no recrutamento de neutrófilos em diferentes focos inflamatórios, incluindo espécies obtidas a partir de amostras de tecido bronquial (KOLLS; LINDEN, 2004), lavado broncoalveolar e muco de pacientes asmáticos (SUN et al., 2005). Nossos resultados mostram que PBMC de crianças asmáticas moderadas produziram espontaneamente baixas quantidades de IL17, quando comparados com crianças não asmáticas (Figura 17; Mann Whitney< $<<0,05)$. Estes dados contradizem aqueles encontrados na literatura, que mostram que indivíduos asmáticos apresentaram altas quantidades de RNA mensageiro de IL-17 quando comparados com indivíduos não asmáticos (BULLENS et al., 2006). Além disso, crianças asmáticas graves apresentam maiores concentrações de IL-17 no soro do que crianças asmáticas leves e moderadas (AGACHE et al., 2010).

A regulação desse quadro inflamatório é essencial para o funcionamento adequado das respostas imunes e controle das repostas alérgicas exarcebadas. Dentro desse contexto a IL-10 atua regulando negativamente a produção de citocinas por fagócitos mononucleares, células natural killer e linfócitos Th2 (D'ANDREA et al., 1993). Nossos resultados mostram uma baixa produção espontânea de IL-10 por PBMC de crianças asmáticas moderadas (Figura 18; Mann Whitney<p<0,05). Esses dados sugerem que essa baixa produção observada permite uma maior liberação de citocinas pró-inflamatórias, contribuindo desta forma para a inflamação das vias aéreas destes pacientes (XYSTRAKIS et al., 2006).

Sabe-se que a resposta imune adaptativa inicia-se com a ativação dos linfócitos T após a apresentação do antígeno. O direcionamento da resposta imune para o padrão Th1 ou Th2 é influenciado por fatores, como a natureza do antígeno, sinais coestimuladores e o ambiente de citocinas em que essas células se encontram (DE MELLO et al., 2009). Assim, enquanto a IL-4 produzida por basófilos induz uma diferenciação para Th2, a IL-12 induz uma diferenciação para Th1 (SOKOL; MEDZHITOV, 2010). Na imunopatogenia da asma é bem conhecido o papel das células Th2, sendo indivíduos asmáticos possuidores de maior número de células $\mathrm{T}$ alérgeno-específicas secretoras de IL-4 e IL-5 (KAY, 1996). Nossos resultados mostram 
uma baixa produção de IL-4 por PBMC de crianças asmáticas leves, moderadas e graves após estímulo com LPS (Figura 19; Mann Whitney, $\mathrm{p}<0,05$ ). Mais uma vez a baixa produção dessa citocina pode estar relacionada com o estímulo utilizado no experimento, no caso, o LPS, que inibe a produção de citocinas do tipo Th2 (KOCH et al., 2007).

No entanto, observamos uma alta produção espontânea de IL-5 por PBMC de crianças asmáticas leves (Figura 20; Mann Whitney, p<0,05). Este resultado é esperado de acordo com a literatura, pois crianças asmáticas produzem altas quantidades dessa citocina no soro (KOTSIMBOS; HAMID, 1997), o que não é observado em relação à produção de IL-4 (Figura 19; Mann Whitney, p<0,05). Estes resultados podem sugerir que a IL-4 e a IL-5, apesar de possuírem uma via comum de ativação, podem possuir vias de regulação distintas no contexto da asma.

Quanto à produção de citocinas Th1, nossos resultados mostram que PBMC de crianças asmáticas graves produziram baixas quantidades de IL-12p70, com ou sem estímulo de LPS (Figura 14; Mann Whitney, p<0,05), e PBMC de crianças asmáticas leves produziram espontaneamente baixas quantidades de IFN- $\gamma$ (Figura 15; Mann Whitney, p<0,05). Essa observação reforçam nossas suspeitas de que a baixa produção espontânea de citocinas Th1 poderia ser um defeito permanente e não transitório dos PBMC de pacientes com sibilância e asma. Ainda, essa "falha" se mostra independente da exposição à endotoxina, como um defeito genético em alguma molécula envolvida na ativação do eixo IL-12/IFN- $\gamma$, conforme discutido anteriormente

Podemos observar um consenso nos resultados obtidos entre os grupos de sibilantes e asmáticos. Essa baixa produção de IL-12 e IFN- $\gamma$ também encontrada nos asmáticos não está correlacionada com os polimorfismos nos genes de CD14 (C-159T) e TLR4 (Asp299Gly) (Tabelas 10 e 11; Fischer, p<0,05). Além disso, nossos resultados (Tabela 10; Fischer $<\mathrm{p}<0,05$ ) estão em consenso com os estudos que demonstram que o polimorfismo Asp299Gly no gene de TLR4 não está associado com o desenvolvimento do fenótipo de asma (NOGUCHI et al., 2004; SMIT et al., 2007). Estudos de associações de polimorfismos em populações humanas continuam controversos, outros autores demonstram que o polimorfismo Asp299Gly no gene de TLR4 está associado com a alta prevalência da asma em crianças escolares (FAGERAS; BOTTCHER et al., 2004; SENTHILSELVAN et al., 2008) e em crianças da Turquia (SACKESEN et al., 2005). Além disso, demonstram associação entre o polimorfismo de TLR4 Asp299Gly com o aumento da gravidade da asma (YANG et al., 2004). Provavelmente essas 
controvérsias se devem ao fato dos genes codificantes de TLR apresentarem alta variabilidade em populações humanas, não permitindo uma associação adequada e esclarecida entre polimorfismos e a ocorrência de doenças alérgicas (YANG et al., 2004; PHIPPS et al., 2007).

Esta literatura conflitante também é observada em relação ao polimorfismo de CD14. Após o artigo inicial do polimorfismo na região promotora do gene que codifica o CD14, demonstrando associação com os níveis de IgE e de CD14 solúvel no soro (BALDINI et al., 1999), um grande número de estudos foi realizado correlacionando este polimorfismo nos diferentes grupos éticos. Os nossos dados concordaram com vários estudos, demonstrando que o polimorfismo no gene de CD14 não está associado com o desenvolvimento do fenótipo da asma (Tabela 11; Fischer, $p<0,05$ ). Esses estudos foram realizados em crianças caucasianas (HEINZMANN et al., 2003), em crianças chinesas (LEUNG et al., 2003), nas crianças alemãs (KABESCH, 2004), nas crianças japonesas (NISHIMURA et al., 2006) e na população de jovens fazendeiros da Dinamarca (SMIT et al., 2007). Entretanto há trabalhos mostrando que indivíduos que possuem os dois alelos polimórficos -159C apresentaram altos níveis de CD14 solúvel no soro e baixos níveis de $\operatorname{IgE}$ total, fenômeno observado principalmente em crianças atópicas (BALDINI et al., 1999; YANG et al., 2006). Além disso, há trabalhos que demonstram associação entre o polimorfismo de CD14 com o desenvolvimento do fenótipo da asma em crianças do nordeste dos Estados Unidos (LITONJUA et al., 2005).

Como realizado nas crianças sibilantes, também avaliamos se o polimorfismo de CD14 está associado com a sensibilização aos alérgenos e com a produção de citocinas por PBMC de crianças asmáticas, estimuladas ou não com LPS. Nossos resultados demonstraram que o polimorfismo de CD14 está associado com sensibilização aos alérgenos de fungos (Tabela 12; Fischer, ${ }^{*} \mathrm{p}<0.05$ ). Estes resultados confirmam mais uma vez a importância do CD14 para a resposta imune a fungos. Não foi possível realizar a associação com o alérgeno Per a1, uma vez que não foi feito o teste cutâneo para este antígeno nas crianças asmáticas. Quanto à produção de citocinas, o número de indivíduos foi insuficiente em cada grupo para realizar as análises estatísticas.

A diversidade na composição étnica da população brasileira é um desafio a mais para definição da relação desse polimorfismo com as características da asma. Como podemos observar, os dados relacionados aos polimorfismos de TLR4 e CD14 
são muito conflitantes, mostrando que a informação sobre o papel de alguns fatores genéticos no desenvolvimento da asma permanece incompleta.

Em suma, observamos que PBMC de crianças asmáticas estimuladas ou não com LPS produziram baixas quantidades de IL-12p70, IFN- $\gamma$, IL-17, IL-10 e IL-4, e altas quantidades de IL-5 basal. A produção de TNF- $\alpha$ foi equivalente entre os grupos estudados e os polimorfismos nos genes de CD14 e TLR não estão associados ao fenótipo da asma. Os estudos com as crianças asmáticas reforçam os achados em crianças sibilantes, tornando ainda maior a necessidade de avaliar a hipótese de que essas patologias são geradas por uma "falha", diminuição da reposta de perfil Th1 e que consequentemente leva a exacerbação da resposta de perfil Th2. 


\section{CONCLUSÕES PARCIAIS}

1. As crianças asmáticas foram sensibilizadas principalmente por Dermatophagoides pteronyssinus, D. farinae e Blomia tropicalis;

2. Não há diferença na produção de TNF- $\alpha$ por PBMC de crianças asmáticas e não asmáticas;

3. PBMC de crianças asmáticas graves produziram baixas quantidades de IL-12p70 espontaneamente e mesmo estimuladas com LPS quando comparados com crianças não asmáticas;

4. Há uma produção espontânea reduzida de IFN- $\gamma$ por PBMC de crianças asmáticas leves quando comparada com crianças não asmáticas;

5. PBMC de crianças asmáticas moderadas produziram espontaneamente baixas quantidades de IL-17 e IL-10 quando comparados com crianças não asmáticas;

6. Há uma produção espontânea aumentada de IL-5 por PBMC de crianças asmáticas leves quando comparada com crianças não asmáticas;

7. PBMC de crianças asmáticas leves, moderadas e graves produziram baixas quantidades de IL-4 após estímulo com LPS quando comparados com crianças não asmáticas;

8. Não observamos uma associação entre os polimorfismos nos genes de TLR4 e CD14 ao fenótipo da asma. 


\section{CONSIDERAÇAÇÕES FINAIS E PERSPECTIVAS FUTURAS}

Em conjunto, nossos dados demonstraram que PBMC estimuladas ou não com LPS de crianças sibilantes e asmáticas produziram baixas quantidades de IL-12 e IFN- $\gamma$ quando comparado com crianças não sibilantes e não asmáticas. A produção reduzida dessas citocinas pode influenciar na alta incidência de infecções respiratórias em crianças sibilantes. Além disso, pode estar correlacionado com o direcionamento da produção de citocinas para um padrão Th2.

Além dos estudos envolvendo a produção de citocinas, observamos que os polimorfismos de CD14 e TLR4 não estão correlacionados com os fenótipos da sibilância e da asma nas crianças brasileiras. Observamos ainda que as crianças com genótipo polimórfico T-159T de CD14 foram mais sensíveis aos alérgenos de barata e fungos, e PBMC de crianças não sibilantes que apresentaram este genótipo produzem altas quantidades de IFN- $\gamma$ e IL-10 espontaneamente. Apesar de não mostrarem uma influência direta do polimorfismo no CD14 com o desenvolvimento dos fenótipos de sibilância e asma, estes resultados mostram que essa molécula desempenha um papel importante na regulação da ativação e função das repostas imunes analisadas.

Essas respostas relacionadas com a ativação do eixo IL-12/IFN- $\gamma$ e polimorfismos de CD14 necessitam de uma análise mais aprofundada para serem esclarecidas no contexto do desenvolvimento da sibilância e da asma. Para melhor caracterizarmos essa diminuição de IL-12 e IFN- $\gamma$, pretendemos futuramente avaliar a presença de defeitos transitórios e/ou permanentes de moléculas envolvidas na ativação do eixo IL-12/IFN- $\gamma$, em células de pacientes com sibilância recorrente, e a participação desses no estabelecimento dessa desordem. Além disso, pretendemos aumentar o número de indivíduos estudados para uma avaliação definitiva sobre estes polimorfismos e sua associação com as respostas imunes na sibilância e asma. De uma forma geral, esses duas observações do nosso trabalho trazem novas perspectivas e alternativas para o estudo de duas patologias marcadas pelo estabelecimento de dogmas científicos e permanentes dúvidas sobre seus estabelecimento e desenvolvimento. 


\section{REFERÊNCIAS}

ADACHI, M., et al. IL-10 induces a Th2 cell tolerance in allergic asthma. Int. Arch. Allergy Immunol., v. 118, n. 2-4, p. 391-394, Feb-Apr, 1999.

AGACHE, I., et al. Increased serum IL-17 is an independent risk factor for severe asthma. Respir. Med., v., n., p., Mar 23, 2010.

AGARWAL, R; GUPTA, D. Severe asthma and fungi: current evidence. Med. Myco.l, v., n., p., Jul 22, 2010.

AKIRA, S; HEMMI, H. Recognition of pathogen-associated molecular patterns by TLR family. Immunol. Lett., v. 85, n. 2, p. 85-95, Jan 22, 2003.

BABU, K. S., et al. Role of tumor necrosis factor alpha in asthma. Immunol. Allergy Clin. North. Am., v. 24, n. 4, p. 583-597, v-vi, Nov, 2004.

BACHARIER, L. B., et al. Diagnosis and treatment of asthma in childhood: a PRACTALL consensus report. Allergy, v. 63, n. 1, p. 5-34, Jan, 2008.

Bacharier, L. B. Severe intermittent wheezing in preschool children: a distinct phenotype. J. Allergy Clin. Immunol., v. 119, n. 3, p. 604-610, Mar, 2007.

BALDINI, M., et al. A Polymorphism in the 5' flanking region of the CD14 gene is associated with circulating soluble CD14 levels and with total serum immunoglobulin E. Am. J. Respir. Cell Mol. Biol., v. 20, n. 5, p. 976-983, May, 1999.

BARTON, G. M; MEDZHITOV, R. Toll-like receptor signaling pathways. $\underline{\text { Science, }}$. 300, n. 5625, p. 1524-1525, Jun 6, 2003.

BAYARDELLE, P. Environmental endotoxin and asthma. Am. J. Respir. Crit. Care Med., v. 168, n. 2, p. 257-258; author reply 258, Jul 15, 2003.

BERNSTEIN, D. I., et al. Diisocyanate asthma and gene-environment interactions with IL4RA, CD-14, and IL-13 genes. Ann. Allergy Asthma Immunol., v. 97, n. 6, p. 800806, Dec, 2006.

BERRY, M., et al. TNF-alpha in asthma. Curr. Opin. Pharmacol., v. 7, n. 3, p. 279-282, Jun, 2007.

BERTELSEN, R. J., et al. Childhood asthma and early life exposure to indoor allergens, endotoxin and beta(1,3)-glucans. Clin. Exp. Allergy, v. 40, n. 2, p. 307-316, Feb, 2010.

BEUTLER, B; RIETSCHEL, E. T. Innate immune sensing and its roots: the story of endotoxin. Nat. Rev. Immunol., v. 3, n. 2, p. 169-176, Feb, 2003.

BLANCO-QUIROS, A., et al. Decreased interleukin-12 levels in umbilical cord blood in children who developed acute bronchiolitis. Pediatr. Pulmonol., v. 28, n. 3, p. 175180, Sep, 1999. 
BOEHM, U., et al. Cellular responses to interferon-gamma. Annu. Rev. Immunol., v. 15, n., p. 749-795, 1997.

BUCKOVA, D., et al. Polymorphisms of the CD14 gene and atopic phenotypes in Czech patients with IgE-mediated allergy. J. Hum. Genet., v. 51, n. 11, p. 977-983, 2006.

BULLENS, D. M., et al. IL-17 mRNA in sputum of asthmatic patients: linking T cell driven inflammation and granulocytic influx? Respir. Res., v. 7, n., p. 135, 2006.

BUNNAG, C., et al. Epidemiology and current status of allergic rhinitis and asthma in Thailand -- ARIA Asia-Pacific Workshop report. Asian Pac. J. Allergy Immunol., v. 27, n. 1, p. 79-86, Mar, 2009.

CAMELO-NUNES, I. C. e SOLE, D. Cockroach allergy: risk factor for asthma severity. J. Pediatr. (Rio J), v. 82, n. 5, p. 398-399; author reply 399-400, Sep-Oct, 2006.

CELEDON, J. C., et al. Exposure to dust mite allergen and endotoxin in early life and asthma and atopy in childhood. J. Allergy Clin. Immunol., v. 120, n. 1, p. 144-149, Jul, 2007.

CEMBRZYNSKA-NOWAK, M., et al. Elevated release of tumor necrosis factor-alpha and interferon-gamma by bronchoalveolar leukocytes from patients with bronchial asthma. Am. Rev. Respir. Dis., v. 147, n. 2, p. 291-295, Feb, 1993.

CHONG NETO, H. J., et al. Associated factors for recurrent wheezing in infancy. Allergy, v. 65, n. 3, p. 406-407, Mar, 2010.

D'ANDREA, A., et al. Interleukin 10 (IL-10) inhibits human lymphocyte interferon gamma-production by suppressing natural killer cell stimulatory factor/IL-12 synthesis in accessory cells. J. Exp. Med., v. 178, n. 3, p. 1041-1048, Sep 1, 1993.

DE MARCO, R., et al. Influence of early life exposures on incidence and remission of asthma throughout life. J. Allergy Clin. Immunol., v. 113, n. 5, p. 845-852, May, 2004.

DE MELLO, L. M., et al. TH1/TH2 balance in concomitant immediate and delayedtype hypersensitivity diseases. Immunol. Lett., v. 124, n. 2, p. 88-94, Jun 4, 2009.

DEVULAPALLI, C. S., et al. Severity of obstructive airways disease by age 2 years predicts asthma at 10 years of age. Thorax, v. 63, n. 1, p. 8-13, Jan, 2008.

DOUCET, C., et al. Interleukin (IL) 4 and IL-13 act on human lung fibroblasts. Implication in asthma. J. Clin. Invest., v. 101, n. 110, p. 2129-39, May 15, 1998.

DOUWES, J., et al. Does environmental endotoxin exposure prevent asthma? Thorax, v. 57, n. 1, p. 86-90, Jan, 2002. 
DUFF, A. L., et al. Risk factors for acute wheezing in infants and children: viruses, passive smoke, and IgE antibodies to inhalant allergens. Pediatrics, v. 92, n. 4, p. 535540, Oct, 1993.

EDER, W; VON MUTIUS, E. Hygiene hypothesis and endotoxin: what is the evidence? Curr. Opin. Allergy Clin. Immunol., v. 4, n. 2, p. 113-117, Apr, 2004.

ENK, A. H., et al. Inhibition of Langerhans cell antigen-presenting function by IL-10. A role for IL-10 in induction of tolerance. J. Immunol., v. 151, n. 5, p. 2390-2398, Sep 1, 1993.

ERB, K. J; LE GROS, G. The role of Th2 type CD4+ T cells and Th2 type CD8+ T cells in asthma. Immunol. Cell. Biol., v. 74, n. 2, p. 206-208, Apr, 1996.

ERRIDGE, C., et al. Oxidized phospholipid inhibition of toll-like receptor (TLR) signaling is restricted to TLR2 and TLR4: roles for CD14, LPS-binding protein, and MD2 as targets for specificity of inhibition. J. Biol. Chem., v. 283, n. 36, p. 2474824759, Sep 5, 2008.

FAGERAS BOTTCHER, M., et al. A TLR4 polymorphism is associated with asthma and reduced lipopolysaccharide-induced interleukin-12(p70) responses in Swedish children. J. Allergy Clin. Immunol., v. 114, n. 3, p. 561-567, Sep, 2004.

FINBERG, R. W., et al. Cell activation by Toll-like receptors: role of LBP and CD14. $\underline{J}$ Endotoxin Res., v. 10, n. 6, p. 413-418, 2004.

FOSTER, S. L; MEDZHITOV, R. Gene-specific control of the TLR-induced inflammatory response. Clin. Immunol., v. 130, n. 1, p. 7-15, Jan, 2009.

GERN, J. E. The ABCs of Rhinoviruses, Wheezing, and Asthma. J. Virol., v., n., p., Apr 7, 2010.

GILLESPIE, J., et al. Endotoxin exposure, wheezing, and rash in infancy in a New Zealand birth cohort. J. Allergy Clin. Immunol., v. 118, n. 6, p. 1265-1270, Dec, 2006.

GUPTA, V., et al. Association of G-308A TNF-alpha polymorphism with bronchial asthma in a North Indian population. J. Asthma, v. 42, n. 10, p. 839-841, Dec, 2005.

HARGREAVE, F. E; NAIR, P. The definition and diagnosis of asthma. Clin. Exp. Allergy, v. 39, n. 11, p. 1652-1658, Nov, 2009.

HEIDEMANN, J., et al. Expression of IL-12-related molecules in human intestinal microvascular endothelial cells is regulated by TLR3. Am. J. Physiol. Gastrointest. Liver Physiol., v. 293, n. 6, p. G1315-1324, Dec, 2007.

HEINZMANN, A., et al. Promoter polymorphisms of the CD14 gene are not associated with bronchial asthma in Caucasian children. Eur. J. Immunogenet., v. 30, n. 5, p. 345348, Oct, 2003. 
HOLT, P. G. The role of airway dendritic cell populations in regulation of T-cell responses to inhaled antigens: atopic asthma as a paradigm. J. Aerosol. Med., v. 15, n. 2, p. 161-168, Summer, 2002.

ILLI, S., et al. Perennial allergen sensitisation early in life and chronic asthma in children: a birth cohort study. Lancet, v. 368, n. 9537, p. 763-770, Aug 26, 2006.

IWASAKI, A; MEDZHITOV, R. Regulation of adaptive immunity by the innate immune system. Science, v. 327, n. 5963, p. 291-295, Jan 15, 2010

IYODA, M., et al. IL-17A and IL-17F stimulate chemokines via MAPK pathways (ERK1/2 and p38 but not JNK) in mouse cultured mesangial cells: synergy with TNFalpha and IL-1beta. Am. J. Physiol. Renal Physiol., v. 298, n. 3, p. F779-787, Mar, 2010.

KABESCH, M. Candidate genes and the genetic epidemiology of asthma. Paediatr.Respir. Rev., v. 5 Suppl A, n., p. S23-25, 2004.

KAY, A. B. TH2-type cytokines in asthma. Ann. N. Y. Acad. Sci., v. 796, n., p. 1-8, Oct 31, 1996.

$\mathrm{KOCH}$, A., et al. Effect of bacterial endotoxin LPS on expression of INF-gamma and IL-5 in T-lymphocytes from asthmatics. Clin. Immunol., v. 125, n. 2, p. 194-204, Nov, 2007.

KOLLS, J. K; LINDEN, A. Interleukin-17 family members and inflammation. Immunity, v. 21, n. 4, p. 467-476, Oct, 2004.

KOOPMAN, L. P., et al. Increased serum IL-10/IL-12 ratio in wheezing infants. Pediatr. Allergy Immunol., v. 14, n. 2, p. 112-119, Apr, 2003.

KOPP, E. B; MEDZHITOV, R. The Toll-receptor family and control of innate immunity. Curr. Opin. Immunol., v. 11, n. 1, p. 13-18, Feb, 1999.

KOTSIMBOS, A. T; HAMID, Q. IL-5 and IL-5 receptor in asthma. Mem. Inst. Oswaldo Cruz, v. 92 Suppl 2, n., p. 75-91, 1997.

KROUWELS, F. H. Anti-tumor necrosis factor-alpha in asthma. Am. J. Respir. Crit. Care Med., v. 175, n. 3, p. 288; author reply 288-289, Feb 1, 2007.

KURUKULAARATCHY, R. J., et al. Characterization of wheezing phenotypes in the first 10 years of life. Clin. Exp. Allergy, v. 33, n. 5, p. 573-578, May, 2003.

LAI, C. K., et al. Global variation in the prevalence and severity of asthma symptoms: phase three of the International Study of Asthma and Allergies in Childhood (ISAAC). Thorax, v. 64, n. 6, p. 476-483, Jun, 2009.

LAMPINEN, M., et al. IL-5 and TNF-alpha participate in recruitment of eosinophils to intestinal mucosa in ulcerative colitis. Dig. Dis. Sci., v. 46, n. 9, p. 2004-2009, Sep, 2001 . 
LEE, Y. C., et al. Serum levels of interleukins (IL)-4, IL-5, IL-13, and interferongamma in acute asthma. J. Asthma, v. 38, n. 8, p. 665-671, Dec, 2001.

LEUNG, T. F., et al. The C-159T polymorphism in the CD14 promoter is associated with serum total IgE concentration in atopic Chinese children. Pediatr. Allergy Immunol., v. 14, n. 4, p. 255-260, Aug, 2003.

LEVAN, T. D., et al. Polymorphisms in the CD14 gene associated with pulmonary function in farmers. Am. J. Respir. Crit. Care Med., v. 171, n. 7, p. 773-779, Apr 1, 2005.

LITONJUA, A. A., et al. Polymorphisms in the 5' region of the CD14 gene are associated with eczema in young children. J. Allergy Clin. Immunol., v. 115, n. 5, p. 1056-1062, May, 2005.

MA, X; TRINCHIERI, G. Regulation of interleukin-12 production in antigenpresenting cells. Adv. Immunol., v. 79, n., p. 55-92, 2001.

MALLOL, J., et al. Wheezing during the first year of life in infants from low-income population: a descriptive study. Allergol. Immunopathol. (Madr), v. 33, n. 5, p. 257263, Sep-Oct, 2005.

MARTINEZ, F. D. Development of wheezing disorders and asthma in preschool children. Pediatrics, v. 109, n. 2 Suppl, p. 362-367, Feb, 2002a.

MARTINEZ, F. D. What have we learned from the Tucson Children's Respiratory Study? Paediatr. Respir. Rev., v. 3, n. 3, p. 193-197, Sep, 2002 b.

MARTINEZ, F. D; HELMS, P. J. Types of asthma and wheezing. Eur. Respir. J. Suppl., v. 27, n., p. 3s-8s, Jul, 1998.

MARTINEZ, F. D., et al. Asthma and wheezing in the first six years of life. The Group Health Medical Associates. N. Engl. J. Med., v. 332, n. 3, p. 133-138, Jan 19, 1995.

MATRICARDI, P. M; BONINI, S. High microbial turnover rate preventing atopy: a solution to inconsistencies impinging on the Hygiene hypothesis? Clin. Exp. Allergy, v. 30, n. 11, p. 1506-1510, Nov, 2000.

MATRICARDI, P. M., et al. Exposure to foodborne and orofecal microbes versus airborne viruses in relation to atopy and allergic asthma: epidemiological study. Bmj, v. 320, n. 7232, p. 412-417, Feb 12, 2000.

MCGETTRICK, A. F; O'NEILL, L. A. Regulators of TLR4 signaling by endotoxins. Subcell. Biochem., v. 53, n., p. 153-171, 2010.

MEDZHITOV, R; ANEWAY, C. A., JR. Innate immunity: the virtues of a nonclonal system of recognition. Cell, v. 91, n. 3, p. 295-298, Oct 31, 1997.

MEDZHITOV, R., et al. A human homologue of the Drosophila Toll protein signals activation of adaptive immunity. Nature, v. 388, n. 6640, p. 394-397, Jul 24, 1997. 
MICHEL, O. Role of house-dust endotoxin exposure in aetiology of allergy and asthma. Mediators Inflamm., v. 10, n. 6, p. 301-304, Dec, 2001.

MICHEL, O., et al. Domestic endotoxin exposure and clinical severity of asthma. $\underline{\text { Clin }}$ Exp. Allergy, v. 21, n. 4, p. 441-448, Jul, 1991.

MORGAN, W. J; MARTINEZ, F. D. Risk factors for developing wheezing and asthma in childhood. Pediatr. Clin. North Am., v. 39, n. 6, p. 1185-1203, Dec, 1992.

MORGAN, W. J., et al. Outcome of asthma and wheezing in the first 6 years of life: follow-up through adolescence. Am. J. Respir. Crit. Care Med., v. 172, n. 10, p. 12531258, Nov 15, 2005.

MOVAHEDI, M., et al. IL-10, TGF-beta, IL-2, IL-12, and IFN-gamma cytokine gene polymorphisms in asthma. J. Asthma, v. 45, n. 9, p. 790-794, Nov, 2008.

MUNTHE-KAAS, M. C., et al. CD14 polymorphisms and serum CD14 levels through childhood: a role for gene methylation? J. Allergy Clin. Immunol., v. 125, n. 6, p. 13611368, Jun, 2010.

NADLER, M. J., et al. Signal transduction by the high-affinity immunoglobulin E receptor Fc epsilon RI: coupling form to function. Adv. Immunol., v. 76, n., p. 325-355, 2000 .

NISHIMURA, F., et al. Failure to find an association between CD14-159C/T polymorphism and asthma: a family-based association test and meta-analysis. Allergol. Int., v. 55, n. 1, p. 55-58, Mar, 2006.

NOGUCHI, E., et al. An association study of asthma and total serum immunoglobin E levels for Toll-like receptor polymorphisms in a Japanese population. Clin. Exp. Allergy, v. 34, n. 2, p. 177-183, Feb, 2004.

NUOLIVIRTA, K., et al. Gene polymorphism of IFNG +874 T/A and TLR4 +896 A/G and recurrent infections and wheezing in toddlers with history of bronchiolitis. Pediatr. Infect. Dis. J., v. 28, n. 12, p. 1121-1123, Dec, 2009.

PAGANELLI, R., et al. Selective deficiency of interferon-gamma production in the hyper-IgE syndrome. Relationship to in vitro IgE synthesis. Clin Exp Immunol, v. 84, n. 1, p. 28-33, Apr, 1991.

PAPPU, R., et al. The IL-17 family cytokines in immunity and disease. J. Clin. Immunol., v. 30, n. 2, p. 185-195, Mar, 2010.

PASTORINO, A. C., et al. Sensitisation to aeroallergens in Brazilian adolescents living at the periphery of large subtropical urban centres. Allergol. Immunopathol. (Madr), v. 36, n. 1, p. 9-16, Jan-Feb, 2008.

PERZANOWSKI, M. S; PLATTS-MILLS, T. A. Further confirmation of the relevance of cockroach and dust mite sensitization to inner-city asthma morbidity. Clin. Exp. Allergy, v. 39, n. 9, p. 1291-1293, Sep, 2009. 
PHIPPS, S., et al. The contribution of toll-like receptors to the pathogenesis of asthma. Immunol. Cell Biol., v. 85, n. 6, p. 463-470, Aug-Sep, 2007.

PICCINNI, M. P., et al. Environmental factors favoring the allergen-specific Th2 response in allergic subjects. Ann. N. Y. Acad. Sci., v. 917, n., p. 844-852, 2000.

PRADALIER, A. Late-phase reaction in asthma: basic mechanisms. Int. Arch. Allergy Immunol., v. 101, n. 3, p. 322-325, 1993.

PUNNONEN, J., et al. IL-10 and viral IL-10 prevent IL-4-induced IgE synthesis by inhibiting the accessory cell function of monocytes. J. Immunol., v. 151, n. 3, p. 12801289, Aug 1, 1993.

PUTHOTHU, B., et al. Association of TNF-alpha with severe respiratory syncytial virus infection and bronchial asthma. Pediatr. Allergy Immunol., v. 20, n. 2, p. 157-163, Mar, 2009.

REY NORES, J. E., et al. Soluble CD14 acts as a negative regulator of human T cell activation and function. Eur. J. Immunol., v. 29, n. 1, p. 265-276, Jan, 1999.

REZAZADEH, M., et al. TLR4 polymorphism in Iranian patients with brucellosis. J. Infect., v. 53, n. 3, p. 206-210, Sep, 2006.

RHODES, H. L., et al. A birth cohort study of subjects at risk of atopy: twenty-two-year follow-up of wheeze and atopic status. Am. J. Respir. Crit. Care Med., v. 165, n. 2, p. 176-180, Jan 15, 2002.

ROHDE, G., et al. Association of the ASP299GLY TLR4 polymorphism with COPD. Respir. Med., v. 100, n. 5, p. 892-896, May, 2006.

ROMAN, M., et al. Respiratory syncytial virus infection in infants is associated with predominant Th-2-like response. Am. J. Respir. Crit. Care Med., v. 156, n. 1, p. 190195, Jul, 1997.

ROTHENBERG, M. E; HOGAN, S. P. The eosinophil. Annu. Rev. Immunol., v. 24, n., p. 147-174, 2006.

RULLO, V. E., et al. Respiratory infection, exposure to mouse allergen and breastfeeding: role in recurrent wheezing in early life. Int. Arch. Allergy Immunol., v. 150, n. 2, p. 172-178, 2009.

SACKESEN, C., et al. The effect of CD14 C159T polymorphism on in vitro IgE synthesis and cytokine production by PBMC from children with asthma. Allergy, v., n., p., Jul 1, 2010.

SACKESEN, C., et al. The effect of polymorphisms at the CD14 promoter and the TLR4 gene on asthma phenotypes in Turkish children with asthma. Allergy, v. 60, n. 12, p. 1485-1492, Dec, 2005. 
SAMPSON, A. P. IL-5 priming of eosinophil function in asthma. Clin. Exp. Allergy, v. 31, n. 4, p. 513-517, Apr, 2001.

SCHULZ, O., et al. CD40 triggering of heterodimeric IL-12 p70 production by dendritic cells in vivo requires a microbial priming signal. Immunity, v. 13, n. 4, p. 453462, Oct, 2000.

SENTHILSELVAN, A., et al. Association of polymorphisms of toll-like receptor 4 with a reduced prevalence of hay fever and atopy. Ann. Allergy Asthma Immunol., v. 100, n. 5, p. 463-468, May, 2008.

SIMPSON, A., et al. Endotoxin exposure, CD14, and allergic disease: an interaction between genes and the environment. Am. J. Respir. Crit. Care Med., v. 174, n. 4, p. 386-392, Aug 15, 2006.

SIMPSON, A; MARTINEZ, F. D. The role of lipopolysaccharide in the development of atopy in humans. Clin. Exp. Allergy, v. 40, n. 2, p. 209-223, Feb, 2010.

SMIT, L. A., et al. Atopy and new-onset asthma in young Danish farmers and CD14, TLR2, and TLR4 genetic polymorphisms: a nested case-control study. Clin. Exp. Allergy, v. 37, n. 11, p. 1602-1608, Nov, 2007.

SOKOL, C. L; MEDZHITOV, R. Role of basophils in the initiation of Th2 responses. Curr. Opin. Immunol., v. 22, n. 1, p. 73-77, Feb, 2010.

SOLE, D. [Childhood wheezing]. J. Bras. Pneumol., v. 34, n. 6, p. 337-339, Jun, 2008.

SOLE, D., et al. Prevalence of symptoms of asthma, rhinitis, and atopic eczema among Brazilian children and adolescents identified by the International Study of Asthma and Allergies in Childhood (ISAAC) - Phase 3. J. Pediatr. (Rio J), v. 82, n. 5, p. 341-346, Sep-Oct, 2006.

SOLE, D., et al. International Study of Asthma and Allergies in Childhood (ISAAC): prevalence of asthma and asthma-related symptoms among Brazilian schoolchildren. $\underline{\text { J. }}$ Investig. Allergol. Clin. Immunol., v. 11, n. 2, p. 123-128, 2001.

SUN, Y. C., et al. Sputum interleukin-17 is increased and associated with airway neutrophilia in patients with severe asthma. Chin. Med. J. (Engl), v. 118, n. 11, p. 953956, Jun 5, 2005.

TAMANDL, D., et al. Modulation of toll-like receptor 4 expression on human monocytes by tumor necrosis factor and interleukin-6: tumor necrosis factor evokes lipopolysaccharide hyporesponsiveness, whereas interleukin-6 enhances lipopolysaccharide activity. Shock, v. 20, n. 3, p. 224-229, Sep, 2003.

TANASESCU, C., et al. IL-17 in cutaneous lupus erythematosus. Eur. J. Intern. Med., v. 21, n. 3, p. 202-207, Jun, 2010. 
TREGONING, J. S; SCHWARZE, J. Respiratory viral infections in infants: causes, clinical symptoms, virology, and immunology. Clin. Microbiol. Rev., v. 23, n. 1, p. 7498, Jan, 2010.

TRINCHIERI, G. Interleukin-12 and the regulation of innate resistance and adaptive immunity. Nat. Rev. Immunol., v. 3, n. 2, p. 133-146, Feb, 2003.

VECCHIARELLI, A., et al. Cytokine regulation of low-affinity IgE receptor (CD23) on monocytes from asthmatic subjects. Clin. Exp. Immunol., v. 97, n. 2, p. 248-253, Aug, 1994.

WANG, M. Z., et al. [Roles of IL-4, IL-5 and IgE in childhood cough variant asthma]. Zhongguo Dang Dai Er Ke Za Zhi, v. 8, n. 5, p. 382-384, Oct, 2006.

WEDEMEYER, J. e GALLI, S. J. Mast cells and basophils in acquired immunity. Br. Med. Bull., v. 56, n. 4, p. 936-955, 2000.

WEDEMEYER, J., et al. Roles of mast cells and basophils in innate and acquired immunity. Curr. Opin. Immunol., v. 12, n. 6, p. 624-631, Dec, 2000.

WILSON, N. M. Virus infections, wheeze and asthma. Pediatr. Respir. Rev., v. 4, n. 3, p. 184-192, Sep, 2003.

WRIGHT, A. L., et al. Breast feeding and lower respiratory tract illness in the first year of life. Group Health Medical Associates. Bmj, v. 299, n. 6705, p. 946-949, Oct 14, 1989.

XYSTRAKIS, E., et al. Reversing the defective induction of IL-10-secreting regulatory T cells in glucocorticoid-resistant asthma patients. J. Clin. Invest., v. 116, n. 1, p. 146155, Jan, 2006.

YANG, I. A., et al. Toll-like receptor 4 polymorphism and severity of atopy in asthmatics. Genes Immun., v. 5, n. 1, p. 41-45, Jan, 2004.

YANG, I. A., et al. The role of Toll-like receptors and related receptors of the innate immune system in asthma. Curr. Opin. Allergy Clin. Immunol., v. 6, n. 1, p. 23-28, Feb, 2006.

YAO, W., et al. Evaluation of airway reactivity and immune characteristics as risk factors for wheezing early in life. J. Allergy Clin. Immunol., v. 126, n. 3, p. 483-488 e1, Sep, 2010.

YILMAZ, M., et al. Exposure to house dust endotoxin and allergic sensitization in allergic and nonallergic children living in Adana, Turkey. Turk. J. Pediatr., v. 51, n. 3, p. 225-231, May-Jun, 2009. 


\section{ANEXO A - Termo de consentimento livre e esclarecido - Grupo Experimental.}

\section{TERMO DE CONSENTIMENTO LIVRE E ESCLARECIDO GRUPO EXPERIMENTAL}

\section{ESTUDO: Estudo dos mecanismos moleculares e celulares da imunidade inata que regem a fisiopatogenia da asma.}

Você está sendo convidado(a) a participar do projeto de pesquisa acima citado. $O$ documento abaixo contém todas as informações necessárias sobre a pesquisa que estamos fazendo. Sua colaboração neste estudo será de muita importância para nós, mas se desistir a qualquer momento, isso não causará nenhum prejuízo a você.

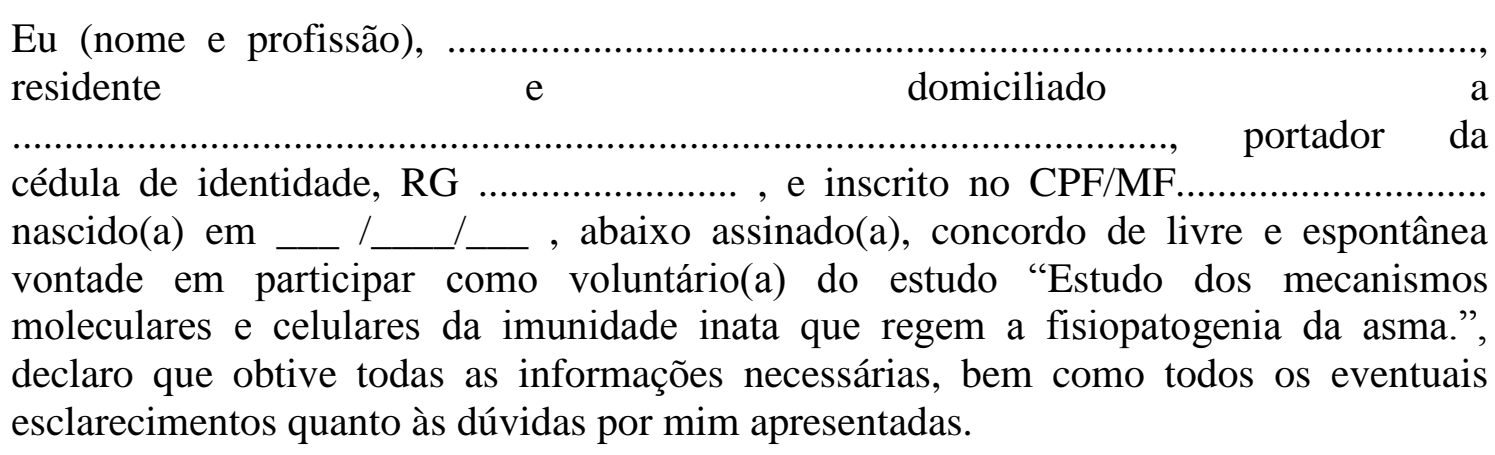

O principal objetivo deste trabalho é estudar avaliação celular e molecular das células que estão possivelmente implicadas no desenvolvimento da asma brônquica em crianças.

Estou ciente que:

I) O estudo se faz necessário para que se possam descobrir as possíveis causas da doença denominada "Asma”;

II) Serão realizados:

a) exame de sangue consistirá de não mais de $20 \mathrm{ml}$ de sangue a serem extraídos em um período de 6 meses, sendo que cada amostra será de não mais de $10 \mathrm{ml}$. Os riscos da retirada de sangue são hematoma local (rouxidão), algum desconforto e, raramente, tontura.

III) Essa(s) coleta(s) será(ao) feita(s) apenas para este estudo e, para os indivíduos com asma ou atopia, em nada influenciará (influenciarão) o meu tratamento; não vai (vão) me curar; não vai (vão) me causar nenhum problema, exceto o pequeno incômodo de dor no momento da coleta (introdução da agulha para retirada do sangue).

IV) A participação neste projeto não tem objetivo de me submeter a um tratamento, bem como não me acarretará qualquer ônus pecuniário com relação aos procedimentos médico-clínico-terapêuticos efetuados com o estudo;

V) Tenho a liberdade de desistir ou de interromper a colaboração neste estudo no momento em que desejar, sem necessidade de qualquer explicação; 
VI) A desistência não causará nenhum prejuízo à minha saúde ou bem estar físico. Não virá interferir no atendimento ou tratamento médico;

VII) Os resultados obtidos durante este ensaio serão mantidos em sigilo, mas concordo que sejam divulgados em publicações científicas, desde que meus dados pessoais não sejam mencionados;

VIII) Caso eu desejar, poderei pessoalmente tomar conhecimento dos resultados, ao final desta pesquisa:

( ) Desejo conhecer os resultados desta pesquisa.

( ) Não desejo conhecer os resultados desta pesquisa.

Estes estudos podem melhorar o entendimento da doença levando a formas mais eficazes de diagnóstico e tratamento no futuro. É provável que o voluntário em questão não seja beneficiário direto destes avanços.

Quaisquer dúvidas, que possam ocorrer com relação a esse estudo, poderão ser contatados:

Dr. Antonio Condino Neto na Universidade de São Paulo, Laboratório de Imunodeficiência, Av. Prof. Lineu Prestes 1730, São Paulo -SP 05508-900, telefone (11) 30917435 .

São Paulo, de de 200 .

( ) Paciente

Testemunha 1 :

Nome / RG / Telefone

Testemunha 2 :

Nome / RG / Telefone

Responsável pelo Projeto:

ANGELA FALCAI 
ANEXO B - Termo de consentimento livre e esclarecido (menores de 18 anos).

\section{TERMO DE CONSENTIMENTO LIVRE E ESCLARECIDO (menores de 18 anos)}

ESTUDO: Estudo dos mecanismos moleculares e celulares da imunidade inata que regem a fisiopatogenia da asma.

Seu filho está sendo convidado a participar do presente estudo. $O$ documento abaixo contém todas as informações necessárias sobre a pesquisa que estamos (ou estaremos) fazendo.Leia atentamente.Caso tenha dúvidas, teremos prazer em esclarecê-las. Se concordar, o documento será assinado e só então daremos início ao estudo. Sua colaboração será muito importante para nós. Mas, se quiser desistir a qualquer momento, isto não causará nenhum prejuízo, nem a você, nem ao(à) seu (sua) filho(a).

$\mathrm{Eu}$ RG

, abaixo assinado(a), concordo de livre e espontânea vontade que meu(minha) filho(a) nascido(a) em I , seja

voluntário do estudo "Estudo dos mecanismos moleculares e celulares da imunidade inata que regem a fisiopatogenia da asma". Declaro que obtive todas as informações necessárias e que todas as minhas dúvidas foram esclarecidas.

O principal objetivo deste trabalho é estudar avaliação celular e molecular das células que estão possivelmente implicadas no desenvolvimento da asma brônquica em crianças.

Estou ciente de que:

I) O estudo é necessário para que se possa descobrir as possíveis causas e/ou o tratamento, se apropriado, da doença denominada "Asma";

II) Serão feitas do(a) meu(minha) filho(a);

a) Exame de sangue consistirá de não mais de $20 \mathrm{ml}$ de sangue a serem extraídos em um período de 6 meses, sendo que cada amostra será de não mais de $10 \mathrm{ml}$. Os riscos da retirada de sangue são hematoma local (rouxidão), algum desconforto e, raramente, tontura.

III) Estas coletas serão feitas apenas para este estudo e em nada influenciarão o tratamento de meu (minha) filho(a); e, para os indivíduos com asma ou atopia, em nada influenciará (influenciarão) o meu tratamento; não vai (vão) me curar; não vai (vão) me causar nenhum problema, exceto o pequeno incômodo de dor no momento da coleta (introdução da agulha para retirada do sangue).

IV) A participação neste estudo não tem fins terapêuticos e será sem custo algum para mim;

V) Tenho a liberdade de desistir ou interromper a colaboração neste estudo no momento em que desejar, sem necessidade de dar qualquer explicação; 
VI) A desistência não causará nenhum prejuízo a mim, nem (a) meu (minha) filho(a), nem interferirá no atendimento ou tratamento médicos a que ele(ela) estiver sendo submetido;

VII) Os resultados obtidos durante este estudo serão mantidos em sigilo, mas concordo em que sejam divulgados em publicações científicas, desde que nem o meu nome, nem o de meu filho sejam mencionados;

VIII) Caso eu deseje, poderei tomar conhecimento dos resultados ao final deste estudo;

IX) Poderei contatar a Secretaria da Comissão de Ética em Pesquisa com Seres Humanos - ICB/USP -, no Fone 3091.7733 ou ( fone do pesquisador) para recursos ou reclamações em relação ao presente estudo.

OBS: Assinalar abaixo com (x):

( ) Desejo conhecer os resultados desta pesquisa.

( ) Não desejo conhecer os resultados desta pesquisa.

São Paulo, de de 2004

Testemunha 1:

Nome / RG / Telefone

Testemunha 2 :

Nome / RG / Telefone

Responsável pelo Projeto:

ANGELA FALCAI 
ANEXO C - Termo de consentimento livre e esclarecido da UNIFESP.

\author{
Termo de consentimento livre e esclarecido da Disciplina de Alergia, Imunologia e
}

Reumatologia, Departamento de Pediatria, Escola Paulista de Medicina -

\title{
UNIFESP
}

\section{Termo de consentimento livre e esclarecido}

1. Título do projeto: Estudo dos mecanismos moleculares e celulares da imunidade inata que regem a fisiopatogenia da asma.

2. O principal objetivo deste trabalho é estudar avaliação celular e molecular das células que estão possivelmente implicadas no desenvolvimento da asma brônquica em crianças.

3. Avaliaremos clinicamente essas crianças desde o momento da sua introdução na creche (a cada três meses no período de um ano) aplicando questionários a seus pais ou responsáveis e no final de um ano aplicaremos um teste cutâneo de hipersensibilidade imediata nas crianças para verificarmos a sensibilização alérgica.

4. As poeiras serão coletadas dos pisos e das roupas de cama das creches e residências das crianças com aspirador de pó em horário previamente combinado.

5. O teste cutâneo de hipersensibilidade imediata refere-se a um teste de punctura realizado no antebraço de fácil execução e leitura rápida. Inicialmente, será colocada uma gota de cada solução a ser testada (solução salina, histamina, do alérgeno de ácaro, gato, cão, barata, fungo, pólen) no antebraço dos pacientes e realizadas puncturas. A leitura do teste acontece 15 minutos depois, verificandose o aparecimento de pápulas.

6. Somente no final do estudo poderemos concluir se as crianças desenvolveram alergia e se os níveis de alérgenos e endotoxinas presentes nas poeiras das creches e das residências influenciaram dessa sensibilização alérgica.

7. Em qualquer etapa do estudo, você terá acesso aos profissionais responsáveis pela pesquisa para o esclarecimento de eventuais dúvidas. Os principais investigadores são a Dra Vera E. Vagnozzi Rullo, Dr Gustavo Falbo Wandalsen e Dra Danielle Kirstman Harari que podem ser encontrados na rua dos Otônis 725 tel: 5576-4426; Disciplina de Alergia, Imunologia Clínica e Reumatologia do Departamento de Pediatria da UNIFESP- Escola Paulista de Medicina. Se você tiver alguma consideração ou dúvida sobre ética da pesquisa, entre em contato com o Comitê de Ética em Pesquisa (CEP) - rua Botucatu, 572 - $1^{\text {o }}$ andar - conj 14, 5571-1062, 5539-7162.

8. É garantida a liberdade da retirada de consentimento a qualquer momento e deixar de participar do estudo, sem qualquer prejuízo à continuidade de seu tratamento na Instituição.

9. Direito de confidencialidade - as informações obtidas serão analisadas em conjunto com estudos abertos, ou de resultados que sejam do conhecimento dos pesquisadores.

10. Direito de ser mantido atualizado sobre os resultados parciais das pesquisas, quando em estudos abertos, ou de resultados que sejam de conhecimento dos pesquisadores. 
11. Despesas e compensações: não há despesas pessoais para o participante em qualquer fase do estudo, incluindo exames e consultas. Também não há compensação financeira relacionada a sua participação. Se existir qualquer despesa adicional, ela será absorvida pelo orçamento da pesquisa.

12. Em caso de dano pessoal, diretamente causado pelos procedimentos ou tratamentos propostos neste estudo (nexo causal comprovado), o participante tem direito a tratamento médico na Instituição, bem como às indenizações legalmente estabelecidas.

13. Compromisso do pesquisador de utilizar os dados e o material coletado somente para esta pesquisa.

Acredito ter sido suficientemente informado a respeito das informações que li ou que foram lidas para mim, descrevendo o estudo "Exposição a alérgenos e a endotoxina, sensibilização e expressão clínica da doença alérgica".

Eu discuti com a Dra Vera Esteves Vagnozzi Rullo sobre a minha decisão em participar nesse estudo. Ficaram claros para mim quais são os propósitos do estudo, os procedimentos a serem realizados, seus desconfortos e riscos, as garantias de confidencialidade e de esclarecimentos permanentes. Ficou claro também que minha participação é isenta de despesas e que tenho garantia do acesso a tratamento hospitalar quando necessário. Concordo voluntariamente em participar deste estudo e poderei retirar o meu consentimento a qualquer momento, antes ou durante o mesmo, sem penalidades ou prejuízo ou perda de qualquer benefício que eu possa ter adquirido, ou no meu atendimento neste Serviço.

Assinatura do paciente/ representante legal Data / /

Assinatura da testemunha

Data / /

Declaro que obtive de forma apropriada e voluntária o Consentimento

Livre e Esclarecido deste paciente ou representante legal para a participação neste estudo

Assinatura do Responsável pelo Estudo 
ANEXO D - Questionários aplicados aos pais/responsáveis das crianças em estudo.

Tabela 1 - Questionário sobre as características técnicas das casas investigadas

- Localização da casa- urbana ou rural

- Idade do prédio

- Presença ou não de mofo

- Infestação visível de barata / existência de gatos no quintal

- Total de aposentos

- Número de salas investigadas

- Número de crianças na casa

- Salas localizadas no térreo e em pisos superiores

- Tipo de sistema de ventilação : janela, passiva por ventilador, ativa por ventilador (durante o dia, durante a noite ou finais de semana)

- Material de revestimento das cadeias : madeira, plástico ou tapeçaria.

Tabela 2 - Métodos de limpeza

1) Aspirar e varrer (anotar quantas vezes por semana)

2) Lavar (quantas vezes por semana)

3) Detergente (identificar se usa ou não e em qual local: mesa, piso)

4) Limpeza a seco (quantas vezes por semana)

5) Exterminação de baratas

- por isca ( frequiência mensal e anotar a freqüência de cada escola)

- por spray (HEIDEMANN et al.) 
Tabela 3 - Questionário sobre as características de atendentes e crianças

Número de crianças (número por sala mostrar a média )

Número de atendentes (número por sala)

$\mathrm{N}^{\mathrm{o}}$ de gatos e cães na residência de cada atendente

Número de gatos e cães na residência de cada criança

Freqüência de contato com gato

Frequiência de contato com cão

Gato em casa (total)

Cão em casa (total)

Tabagistas em casa (número)

Tabagistas na creche (número)

\section{$1^{\circ}$ Questionário:}

- Peso de nascimento

- Tempo de aleitamento

- $\mathrm{N}^{\mathrm{o}}$ de irmãos

- Ordem de nascimento

- Padrão alimentar

$2^{\circ}$ Questionário - específico de sintomas onde constam:

- Número de episódios de chiado durante o trimestre

- Gravidade das crises de broncoespasmo

- Tratamento com corticosteróide

- Utilização de esteróide oral no último ano

- Sibilância independente de resfriado

- Número de infecções

- Utilização de antibióticos

- Necessidade de hospitalização

- Faltas na creche

- Presença ou não de alergias na pele

- Presença ou não de alergias oculares

- Desenvolvimento pôndero-estatural

- Exposição à fumaça de cigarro

- Exposição a animais domésticos 


\section{Intensidade de chiado}

$0=$ assintomáticos

$1=$ poucas queixas ou queixas duvidosas

$2=$ queixas leves, claramente presentes, causando pouco ou nenhum desconforto

$3=$ queixas moderadamente graves, causando desconforto acentuado

4= queixas graves, causando alguma interferência com o sono ou outras atividades

físicas, mas não incapacitantes

$5=$ queixas graves e incapacitantes

\section{$3^{\circ}$ Questionário de consumo de medicamentos}

- Ausência de consumo - 0

- Anti-histamínico - 0

- Aminofilinas orais ou endovenosas 200,0 mg

- $\beta 2$ agonista spray dosificador (MDI) - 1 puff

- $\beta 2$ agonista orais : salbutamol -2,0mg; terbutalino $-2,5 \mathrm{mg}$

- Brometo ipratrópio - 20,0mg

- Corticosteróides

- Inalatórios MDI

- Prednisona oral $-0,5 \mathrm{mg}$

Obs: O escore de gravidade do chiado será calculado pelo escore de sintomas + consumo de medicamentos. 


\section{ANEXO E - Perguntas realizadas para classificação da asma.}

- Tem ou teve episódios recorrentes de falta de ar?

- Tem ou teve crises ou episódios recorrentes de chiado no peito?

- Tem tosse persistente, particularmente à noite ou ao acordar?

- Acorda por tosse ou falta de ar?

- Tem tosse, sibilância ou aperto no peito após atividade física?

- Apresenta tosse, sibilância ou aperto no peito após exposição a alérgenos como mofo, poeira domiciliar ou animais, irritantes como fumaça de cigarro ou perfumes, ou após resfriados ou alterações emocionais como riso ou choro?

- Usa alguma medicação quando os sintomas ocorrem, e com que frequência?

- Há alívio dos sintomas após o uso de medicação?

- Tem antecedentes familiares de doenças alérgicas ou asma?

- Tem ou teve sintomas de doenças alérgicas? 